\title{
Psychological therapies for the management of chronic pain (excluding headache) in adults (Review)
}

Williams ACDC, Eccleston C, Morley S

Williams ACDC, Eccleston C, Morley S.

Psychological therapies for the management of chronic pain (excluding headache) in adults.

Cochrane Database of Systematic Reviews 2012, Issue 11. Art. No.: CD007407.

DOI: 10.1002/14651858.CD007407.pub3.

www.cochranelibrary.com 
TABLE OF CONTENTS

HEADER

ABSTRACT

PLAIN LANGUAGE SUMMARY

BACKGROUND

OBJECTIVES

METHODS

RESULTS

Figure 1.

Figure 2.

DISCUSSION

AUTHORS' CONCLUSIONS

ACKNOWLEDGEMENTS

REFERENCES

\section{CHARACTERISTICS OF STUDIES}

DATA AND ANALYSES

Analysis 1.1. Comparison 1 Cognitive behavioural vs active control post-treatment, Outcome 1 Pain.

Analysis 1.2. Comparison 1 Cognitive behavioural vs active control post-treatment, Outcome 2 Disability.

Analysis 1.3. Comparison 1 Cognitive behavioural vs active control post-treatment, Outcome 3 Mood.

Analysis 1.4. Comparison 1 Cognitive behavioural vs active control post-treatment, Outcome 4 Catastrophising. ....................

Analysis 2.1. Comparison 2 Cognitive behavioural vs active control follow-up, Outcome 1 Pain.

Analysis 2.2. Comparison 2 Cognitive behavioural vs active control follow-up, Outcome 2 Disability.

Analysis 2.3. Comparison 2 Cognitive behavioural vs active control follow-up, Outcome 3 Mood.

Analysis 2.4. Comparison 2 Cognitive behavioural vs active control follow-up, Outcome 4 Catastrophising.

Analysis 3.1. Comparison 3 Cognitive behavioural vs treatment as usual, Outcome 1 Pain.

Analysis 3.2. Comparison 3 Cognitive behavioural vs treatment as usual, Outcome 2 Disability.

Analysis 3.3. Comparison 3 Cognitive behavioural vs treatment as usual, Outcome 3 Mood.

Analysis 3.4. Comparison 3 Cognitive behavioural vs treatment as usual, Outcome 4 Catastrophising.

Analysis 4.1. Comparison 4 Cognitive behavioural vs treatment as usual follow-up, Outcome 1 Pain.

Analysis 4.2. Comparison 4 Cognitive behavioural vs treatment as usual follow-up, Outcome 2 Disability.

Analysis 4.3. Comparison 4 Cognitive behavioural vs treatment as usual follow-up, Outcome 3 Mood.

Analysis 4.4. Comparison 4 Cognitive behavioural vs treatment as usual follow-up, Outcome 4 Catastrophising.

Analysis 5.1. Comparison 5 Behavioural vs active control post-treatment, Outcome 1 Pain.

Analysis 5.2. Comparison 5 Behavioural vs active control post-treatment, Outcome 2 Disability.

Analysis 5.3. Comparison 5 Behavioural vs active control post-treatment, Outcome 3 Mood.

Analysis 5.4. Comparison 5 Behavioural vs active control post-treatment, Outcome 4 Catastrophising.

Analysis 6.1. Comparison 6 Behavioural vs active control follow-up, Outcome 1 Pain.

Analysis 6.2. Comparison 6 Behavioural vs active control follow-up, Outcome 2 Disability.

Analysis 6.3. Comparison 6 Behavioural vs active control follow-up, Outcome 3 Mood.

Analysis 6.4. Comparison 6 Behavioural vs active control follow-up, Outcome 4 Catastrophising.

Analysis 7.1. Comparison 7 Behavioural vs treatment as usual post-treatment, Outcome 1 Pain.

Analysis 7.2. Comparison 7 Behavioural vs treatment as usual post-treatment, Outcome 2 Disability.

Analysis 7.3. Comparison 7 Behavioural vs treatment as usual post-treatment, Outcome 3 Mood.

Analysis 7.4. Comparison 7 Behavioural vs treatment as usual post-treatment, Outcome 4 Catastrophising.

Analysis 8.1. Comparison 8 Behavioural vs treatment as usual follow-up, Outcome 1 Pain.

Analysis 8.2. Comparison 8 Behavioural vs treatment as usual follow-up, Outcome 2 Disability.

Analysis 8.3. Comparison 8 Behavioural vs treatment as usual follow-up, Outcome 3 Mood.

APPENDICES

WHAT'S NEW

HISTORY 
[Intervention Review]

\title{
Psychological therapies for the management of chronic pain (excluding headache) in adults
}

\author{
Amanda C de C Williams ${ }^{1}$, Christopher Eccleston ${ }^{2}$, Stephen Morley $3 a$ \\ 1Research Department of Clinical, Educational \& Health Psychology, University College London, London, UK. ${ }^{2}$ Centre for Pain Research, \\ University of Bath, Bath, UK. 3University of Leeds, Leeds, UK
}

$a_{\text {Deceased }}$

Contact address: Amanda C de C Williams, Research Department of Clinical, Educational \& Health Psychology, University College London, Gower Street, London, WC1E 6BT, UK. amanda.williams@ucl.ac.uk, ucjtamw@ucl.ac.uk.

Editorial group: Cochrane Pain, Palliative and Supportive Care Group

Publication status and date: Stable (no update expected for reasons given in 'What's new'), published in Issue 9, 2019.

Citation: Williams ACDC, Eccleston C, Morley S. Psychological therapies for the management of chronic pain (excluding headache) in adults. Cochrane Database of Systematic Reviews 2012, Issue 11. Art. No.: CD007407. DOI: 10.1002/14651858.CD007407.pub3.

Copyright @ 2019 The Cochrane Collaboration. Published by John Wiley \& Sons, Ltd.

\section{A B S T R A C T}

\section{Background}

Psychological treatments are designed to treat pain, distress and disability, and are in common practice. This review updates and extends the 2009 version of this systematic review.

\section{Objectives}

To evaluate the effectiveness of psychological therapies for chronic pain (excluding headache) in adults, compared with treatment as usual, waiting list control, or placebo control, for pain, disability, mood and catastrophic thinking.

\section{Search methods}

We identified randomised controlled trials (RCTs) of psychological therapy by searching CENTRAL, MEDLINE, EMBASE and Psychlit from the beginning of each abstracting service until September 2011. We identified additional studies from the reference lists of retrieved papers and from discussion with investigators.

\section{Selection criteria}

Full publications of RCTs of psychological treatments compared with an active treatment, waiting list or treatment as usual. We excluded studies if the pain was primarily headache, or was associated with a malignant disease. We also excluded studies if the number of patients in any treatment arm was less than 20.

\section{Data collection and analysis}

Forty-two studies met our criteria and 35 (4788 participants) provided data. Two authors rated all studies. We coded risk of bias as well as both the quality of the treatments and the methods using a scale designed for the purpose. We compared two main classes of treatment (cognitive behavioural therapy(CBT) and behaviour therapy) with two control conditions (treatment as usual; active control) at two assessment points (immediately following treatment and six months or more following treatment), giving eight comparisons. For each comparison, we assessed treatment effectiveness on four outcomes: pain, disability, mood and catastrophic thinking, giving a total of 32 possible analyses, of which there were data for 25 .

\section{Main results}

Overall there is an absence of evidence for behaviour therapy, except a small improvement in mood immediately following treatment when compared with an active control. CBT has small positive effects on disability and catastrophising, but not on pain or mood, when compared 
with active controls. CBT has small to moderate effects on pain, disability, mood and catastrophising immediately post-treatment when compared with treatment as usual/waiting list, but all except a small effect on mood had disappeared at follow-up. At present there are insufficient data on the quality or content of treatment to investigate their influence on outcome. The quality of the trial design has improved over time but the quality of treatments has not.

\section{Authors' conclusions}

Benefits of CBT emerged almost entirely from comparisons with treatment as usual/waiting list, not with active controls. CBT but not behaviour therapy has weak effects in improving pain, but only immediately post-treatment and when compared with treatment as usual/ waiting list. CBT but not behaviour therapy has small effects on disability associated with chronic pain, with some maintenance at six months. CBT is effective in altering mood and catastrophising outcomes, when compared with treatment as usual/waiting list, with some evidence that this is maintained at six months. Behaviour therapy has no effects on mood, but showed an effect on catastrophising immediately post-treatment. CBT is a useful approach to the management of chronic pain. There is no need for more general RCTs reporting group means: rather, different types of studies and analyses are needed to identify which components of CBT work for which type of patient on which outcome/s, and to try to understand why.

\section{PLAIN LANGUAGE SUMMARY}

\section{Psychological therapy for adults with longstanding distressing pain and disability}

Many people have pain that lasts for a long time, pain that is not relieved by drugs, surgery or physical therapy. The search for a diagnosis and for pain relief is often long, discouraging and even damaging. For some people, the pain leads to disability, depression, anxiety and social isolation. It is also associated with a tendency to experience much or all in life as ruined by pain, as a catastrophe that is impossible to control. These major life changes are not inevitable and are thought to be at least partly reversible using a treatment which aims to reduce disability and distress despite continuing pain. Treatment is based on robust psychological principles that have developed over 40 years of clinical use.

Our search found 42 trials of treatments which met our criteria, but only 35 provided data in a form that could be used. The two main types of psychological treatment are called cognitive behavioural therapy (CBT) and behaviour therapy. Both focus on helping people to change behaviour that maintains or worsens pain, disability, distress and catastrophic thinking; CBT also directly addresses the thoughts and feelings that are a problem for people with persistent pain. The effects of these two treatments on pain, disability, mood and catastrophic thinking were tested immediately after the treatment, and six months later.

Small to moderate benefits, more for disability, mood and catastrophic thinking than for pain, were found in trials which compared CBT with no treatment. Some of these were still positive six months later. Behaviour therapy showed few and only brief benefits. Psychological therapies can help people with chronic pain reduce negative mood (depression and anxiety), disability, catastrophic thinking, and in some cases, pain. Although the overall effect is positive, we do not know enough about exactly which type of treatment is best for which person. 


\section{B A C K G R O U N D}

Chronic pain is a common problem causing significant distress and disability. Behavioural and cognitive treatments designed to ameliorate pain, distress and disability were first introduced over 40 years ago and are now well established (Fordyce 1968; Keefe Rumble 2004). There are many uncontrolled trials, case studies, observations and clinical reports of treatment methods. Narrative reviews generally report positive effects of psychological treatments on a range of outcomes. In addition there has been periodic publication of meta-analyses and systematic reviews (Flor 1992; Morley 1999) and many recent studies have focused on specific patient groups such as those with musculoskeletal pain syndromes (Dixon 2007; Guzman 2001; Hoffman 2007; Henschke 2010a), and older adults (Ersek 2008).

There is a broad family of treatments included in the general term 'psychological'. In essence, treatments have been developed that are specifically designed to alter psychological processes thought to underlie or significantly contribute to pain, distress and/ or disability. The design of psychological treatments is normally informed by specific theories of the aetiology of human behaviour, or treatments have developed pragmatically through observation and study of response to intervention. In practice there is variety in the types of interventions used, and not all have been evaluated for their effectiveness. The evidence base for psychological therapies is dominated by studies of programmatic and protocolised treatments from a behavioural or cognitive behavioural tradition of clinical psychology. Psychological therapies are commonly presented as being offered after orthodox treatments have failed, when the treatment goal shifts from one of removing or alleviating pain to one of managing pain and its myriad adverse consequences on quality of life. A typical treatment protocol for cognitive behavioural therapy (CBT) will involve methods aimed directly at assessing the thoughts associated with pain, the extent of avoidance of unpleasant thoughts and of painful experiences, and the consequences of these. A common focus is on strongly held beliefs about pain and their relationship with behaviour, which typically worsens the situation in the shorter or longer term. Behavioural methods focus on the identification of behaviour that is contingent on pain, or upon events which provide pain relief or comfort, and the development of behaviour that is contingent instead on goal achievement related to the values of the individual with pain. Most therapies involve education, and many are incorporated within larger treatment programmes involving physical and occupational therapy.

In earlier reviews on this topic (Eccleston 2009a; Morley 1999), we searched for all published randomised controlled trials (RCTs) of interventions described as psychological in nature, and recovered trials principally of behaviour therapy or CBT (Morley 1999). RCTs of interventions for headache were excluded for several reasons: for consistency with the previous review (Eccleston 2009a); and because CBT for headache aims primarily at reducing frequency, duration and intensity of headache pain rather than at rehabilitating despite ongoing pain. Readers are referred to other reviews (Nestoriuc 2007; Nestoriuc 2008; Nicholson 2004), although there are no recent systematic reviews. The Eccleston 2009a review found 52 trials, of which 40 had data that could be entered into a meta-analysis. Trials of CBT provided more data than did behaviour therapy, particularly in relation to active controls. Against active control, CBT improved disability post-treatment, and pain, disability and mood at follow-up, although effect sizes were small. Surprisingly, against doing nothing (treatment as usual or waiting list control), there was only significant improvement for pain post-treatment and mood at follow-up. Again, effect sizes were small. Compared with doing nothing, behaviour therapy improved pain post-treatment, but showed no other benefits, and there were too few trials of behaviour therapy against active control for analysis. This analysis is now out of date and in need of updating (Shojania 2007). Other developments in psychological science have led to new forms of treatments being promoted, and the quality of trials and trial reporting is thought to be improving (Morley 2006). The aim of this review is to summarise the published evidence on the efficacy of psychological treatments for chronic pain in adults and, as far as possible, to investigate key variables that are thought to influence the effectiveness of many psychological interventions.

\section{O B JECT IVES}

To determine the clinical effectiveness of psychological therapy for non-malignant chronic pain (excluding headache) for adults compared with medical or physical treatments, placebo or waiting list controls.

\section{METHODS}

\section{Criteria for considering studies for this review}

\section{Types of studies}

RCTs comparing a credible psychological treatment, or a compound treatment with primary psychological content, with placebo, other active treatment, treatment as usual, or waiting list control, in chronic pain. Studies were excluded if they were concerned with headache or associated with a malignant lifethreatening disease. We judged a psychological treatment credible if it was based on an extant psychological model or framework, and its delivery was from, or was supervised by, a healthcare professional qualified in psychology.

Studies were included if they:

- were available as a full publication or report of a RCT;

- had a design that placed a psychological treatment as an active treatment of primary interest;

- had a psychological treatment with definable psychotherapeutic content;

- were published (or electronically pre-published) in a peerreviewed science journal;

- were with participants reporting chronic pain (i.e. at least three months' duration); and

- had 20 or more participants in each treatment arm at the end of the treatment assessment.

This last criterion of $\mathrm{N} \geq 20$ at post-treatment assessment is an improvement from the Eccleston 2009a review in which we used an entry of $\mathrm{N} \geq 10$. We made this change because of the recognised risk of bias of small numbers (Ioannidis 2005; Nuesch 2009); raising the required $\mathrm{N}$ further would be desirable but would exclude too many studies.

\section{Types of participants}

Adults (aged 18 years or older) reporting pain of at least three months' duration in any body site, not associated with a malignant 
disease process. Patients with only headache or migraine were excluded because the psychological treatments for headache and migraine are sufficiently different, and have a separate history (see Nestoriuc 2007; Nestoriuc 2008; Nicholson 2004), although an up to date systematic review is lacking.

\section{Types of interventions}

Studies were included if at least one trial arm consisted of a psychology intervention, with at least one comparator arm of a placebo condition, other active treatment, treatment as usual or waiting list control.

\section{Types of outcome measures}

- We collected data on descriptive characteristics of participants and characteristics of the treatments, including treatment setting, mode of delivery and therapist.

- Following the Eccleston 2009a review, we collected data for this review on outcomes in the domains of pain experience, disability, negative mood and catastrophic thinking; we recorded and described all outcomes.

\section{Search methods for identification of studies}

\section{Electronic searches}

We identified RCTs of any psychological therapy in the Cochrane Central Register of Controlled Trials (CENTRAL 2011, issue 3), MEDLINE, EMBASE and Psychlit from their inception to September 2011. We identified additional studies from the reference lists of retrieved papers and from discussion with investigators. We performed searching in two sets. We undertook the first prior to the previously published systematic review (Morley 1999). We undertook the second focusing on the 10 years since that review using the same search strategy but taking account of changes in search architecture and terminology (see Eccleston 2009a). There were two further searches to update: in December 2009 covering the period from the beginning of abstracting services to December 2009, and in October 2011, covering the period from December 2009 to September 2011. The search sampled the same databases; an example search strategy is given in Appendix 1. We applied no language restrictions. At least two review authors reviewed all abstracts and they were included on the basis of consensus agreement and discussion with the third review author when necessary.

\section{Data collection and analysis}

\section{Selection of studies}

The trials used in the previous systematic review and meta-analysis (Eccleston 2009a) were automatically included, although some were subsequently excluded by the stricter criteria adopted here. The two searches of the literature since the end of the previous search produced a set of possible abstracts. From these, one rater selected for examination all full papers which might meet the criteria. All three authors read the papers and agreed on exclusion or inclusion: we rated the final set of papers, including those eligible from the previous systematic review, for quality and extracted data.

\section{Data extraction and management}

We used a data extraction book devised jointly by the review authors and used in the previous review (Eccleston 2009a) to extract information on the design of the study, the participants, primary diagnosis, method of treatment and outcome measurement tools used.

The primary data type was measurement using continuous scales. We estimated treatment effects using standardised mean differences by extracting means, standard deviations and sample size at post-treatment and follow-up. When data were not available from published studies or from authors, we did not infer any parameters. Dichotomous outcome data based on clinical improvement were rare and we did not extract these.

\section{Assessment of risk of bias in included studies}

We assessed risk of bias using the recommended Cochrane guidance (Higgins 2011). Of the five suggested 'Risk of bias' categories, we included random sequence generation (selection bias), allocation concealment (selection bias), blinding of outcome assessment (detection bias), incomplete outcome data (attrition bias) and selective reporting (reporting bias). We excluded the option of 'blinding participants and personnel' because neither therapists nor patients can be blinded to whether they deliver or receive treatment. As in the previous review (Eccleston 2009a), we applied a quality rating scale specifically designed for psychological interventions in pain (Yates 2005). Two of the three review authors scored all studies and they reached a consensus after initial comparison or ratings. The quality rating scale was designed specifically for application to psychological treatment studies in pain. It provides an overall total score (0 to 35) consisting of two subscales: a treatment quality scale (0 to 9) covering stated rationale for treatment, manualisation, therapist training and patient engagement; and a design and methods scale (0 to 26) covering inclusion/exclusion criteria, attrition, sample description, minimisation of bias (randomisation method, allocation bias, blinding of assessment, equality of treatment expectations), selection of outcomes, length of follow-up, analyses and choice of control. The first four 'Risk of bias' items from the Cochrane Handbook for Systematic Reviews of Interventions (Higgins 2011) are represented in the design section of the Yates 2005 scale, accounting for up to five of the nine points available.

\section{Measures of treatment effect}

We investigated two classes of psychological treatment and labelled these cognitive behavioural therapy (CBT) and behavioural therapy. CBT involves treatments that include specific direct cognitive therapeutic content. Behavioural therapy includes treatments that are purely behavioural technologies such as biofeedback. Two classes of comparator treatments are investigated and labelled active control and treatment as usual. The active comparator involves a treatment designed to change pain behaviour such as physical therapy, education or medical regime. Patients randomised to the active control within each trial all receive the same treatment. For patients assigned to a waiting list, trials vary in whether they provide further care, and patients vary in whether they seek further care. For patients assigned to treatment as usual, this treatment can consist of anything from regular consultations to access to care. Thus patients in these conditions receive variable and usually unrecorded treatment.

Where a trial had more than two arms, we selected those which best matched our requirements for CBT or behavioural therapy, and where there was a choice, the most intensive version of either: for example, if a trial had an enriched CBT (that is, CBT with additional non-core components such as vocational guidance), a minimum 
CBT and a waiting list condition, we compared the enriched CBT with the waiting list. If both of the treatment conditions were eligible and fell into different analyses, each was compared with the control condition: for example, a trial comparing CBT with behavioural therapy with waiting list control was used both as CBT versus waiting list control, and behavioural therapy versus waiting list control.

We also selected two assessment time points: post-treatment and follow-up. Post-treatment is the assessment point immediately following treatment, and follow-up is the assessment point at least six months after the end of treatment, but not more than 12 months, and the longer of the two if there were two follow-up assessments within this timeframe. Therefore eight separate comparisons were designed comprising two classes of psychological treatment under investigation (CBT, behavioural therapy), two forms of comparator (active control, treatment as usual), and two assessment time points (post-treatment and follow-up). They are labelled:

1. cognitive behavioural versus active control post-treatment;

2. cognitive behavioural versus active control follow-up;

3. cognitive behavioural versus treatment as usual post-treatment;

4. cognitive behavioural versus treatment as usual follow-up;

5. behavioural versus active control post-treatment;

6. behavioural versus active control follow-up;

7. behavioural versus treatment as usual post-treatment;

8. behavioural versus treatment as usual follow-up.

Multiple measurement tools are typically used in each trial. For each comparison we identified four outcomes and labelled them 'pain', 'disability', 'mood' and 'catastrophic thinking'. Although standard trial reporting guidance promotes the definition of primary outcomes (Boutron 2008), most trials do not state a single or preferred a priori primary outcome, so a judgement must be made. From each trial we selected the measure considered most appropriate for each of the three outcomes. When there was more than one measure for an outcome we gave preference to the measure that has documented frequent usage in the field as opposed to a novel measure. Also, when there was a choice between single-item and multi-item self report tools, we chose longer tools on the basis of inferred increased reliability. Not all trials reported data on all three outcomes of pain, disability and mood, and not all trials reported follow-up data.

\section{Assessment of heterogeneity}

We assessed heterogeneity according to the standard method using the $\mathrm{Chi}^{2}$ test and the $\mathrm{I}^{2}$ statistic, calculated for each comparison on each outcome. $I^{2}$ values above $50 \%$ indicate high heterogeneity, between $25 \%$ and $50 \%$ medium heterogeneity, and below $25 \%$ low heterogeneity.

\section{RE S U L T S}

\section{Description of studies}

\section{Results of the search}

The results of the two update searches, in December 2009 and in October 2011, are described separately below.
From the 52 trials which met inclusion criteria in the original review (Eccleston 2009a), 10 trials were dropped. Eight had insufficient psychotherapeutic content, decided following further discussion of what constituted psychotherapeutic content: Astin 2003; Becker 2000; Carson 2005; Dworkin 1994; Dworkin 2002b; Fairbank 2005; Freeman 2002; Strong 1998; one (Turner-Stokes 2003) was a trial to test equivalence of two psychological treatments and therefore on reconsideration did not meet our criteria; one (Buhrman 2004) was the only internet trial, and in the intervening period a separate review of internet interventions had been published (Macea 2010) which made it preferable to exclude internet trials from this systematic review. We included four papers which had been excluded previously: Alaranta 1994 and Spence 1995 (which with redefinition of psychological content met the criteria); Keefe 2004 (wrongly excluded for no non-psychological comparator); and Peters 1990 (which has one outcome, $\mathrm{N}<10$ ). We made renewed efforts to obtain analysable data from six of the 52 studies which had not provided analysable data for Eccleston 2009a. These were Buckelew 1998; Geraets 2005; Marhold 2001; Parker 1988; Smeets 2006 and Strauss 1986. We obtained analysable data from Geraets 2005; Marhold 2001 and Smeets 2006.

The search in December 2009 produced 21 studies. Twelve studies were eligible: Babu 2007; Bliokas 2007; De Souza 2008; Ersek 2008; Falcao 2008; Leeuw 2008; Lindell 2008; Linton 2008; Morone 2008; Wicksell 2008; Woods 2008; Zautra 2008. We also found one longterm follow-up of an existing study follow-up: Smeets 2009. Eight new trials were excluded: inadequate psychotherapeutic content (Kroenke 2009; Machado 2007); internet trial (Lorig 2008); hypnosis trial (Abrahamsen 2008; Castel 2009); unclear randomisation (Ferrari 2006); inadequate N (Menzel 2006); and one which was only a trial plan (Garcia-Campayo 2009). We decided to exclude hypnosis since it fell short of classification as cognitive or behavioural treatment, and requires a systematic review devoted to it. We sought data accessible for analysis from authors and obtained data from Babu 2007; Bliokas 2007 and Zautra 2008.

The search in October 2011 produced 27 studies, of which we eventually included seven: Ehrenborg 2010; Liedl 2011; Litt 2009; Schmidt 2011; Thorsell 2011; Van Koulil 2010; and Wetherell 2011, and a further eligible study Glombiewski 2010b was not found by the electronic search but through an ineligible paper, Glombiewski 2010a, which was produced by that search). Of the 20 excluded studies, 14 had insufficient psychotherapeutic content (Carson 2010; de Sousa 2009; Dufour 2010; Esmer 2010; George 2008; Kapitza 2010; Lamb 2010; Lambeek 2009; Li 2006; Morone 2009; Rendant 2011; Sahin 2011; Turner 2011; Wong 2011); three used hypnosis (Abbott 2010; Abrahamsen 2008; Jensen 2009), one was a non-inferiority trial (Jensen 2009b); one included some participants without chronic pain (Christiansen 2010); and one was not randomly allocated (Schulze 2008). We requested missing data from authors but obtained none for included studies.

This process provided a total of 65 RCTs: Alaranta 1994; Altmaier 1992; Babu 2007; Basler 1997; Bliokas 2007; Bradley 1987; Buckelew 1998; Cook 1998; De Souza 2008; Ehrenborg 2010; Ersek 2003; Ersek 2008; Evers 2002; Falcao 2008; Flor 1993; Geraets 2005; Glombiewski 2010b; Greco 2004; Haldorsen 1998; Hammond 2001; Jensen 1997; Jensen 2001; Johansson 1998; Kaapa 2006; Keefe 1990; Keefe 1996; Keefe 2004; Kole-Snijders 1999; Kraaimaat 1995; Leeuw 2008; Liedl 2011; Lindell 2008; Linton 2008; Litt 2009; Marhold 2001; McCarberg 1999; Mishra 2000; Moore 1985; Newton- 
John 1995; Nicassio 1997; O'Leary 1988; Parker 2003; Peters 1990; Puder 1988; Radojevic 1992; Redondo 2004; Schmidt 2011; Smeets 2006; Spence 1989; Spence 1995; Strauss 1986; Thieme 2003; Thorsell 2011; Turner 1988; Turner 1990; Turner 1993; Turner 2006; Van Koulil 2010; Vlaeyen 1995; Vlaeyen 1996; Wetherell 2011; Wicksell 2008; Williams 1996; Woods 2008; Zautra 2008. Of these, eight did not have analysable data: Alaranta 1994; Buckelew 1998; De Souza 2008; Kole-Snijders 1999; Lindell 2008; O'Leary 1988; Parker 1988; Strauss 1986.

We then applied the new criterion requiring $N \geq 20$ in each arm of a comparison and this excluded 23 trials: Babu 2007; Bradley 1987; Cook 1998; Ersek 2003; Flor 1993; Johansson 1998; Keefe 2004; Liedl 2011; Linton 2008; Marhold 2001; Moore 1985; Newton-John 1995; O'Leary 1988; Peters 1990; Radojevic 1992; Redondo 2004; Spence 1989; Spence 1995; Turner 1990; Turner 1993; Vlaeyen 1995; Wicksell 2008; Woods 2008. We therefore proceeded with 42 trials for the review; of these, seven provided no data: Alaranta 1994; Buckelew 1998; De Souza 2008; Kole-Snijders 1999; Lindell 2008; Parker 1988; Strauss 1986.

\section{Included studies}

Sixteen of the 42 studies are new since the review of 2009 (Eccleston 2009a), meaning that more trials have been published since 2000 than before it. Of the 42 included studies, 24 had two arms, 14 had three and four had four arms. As in the 2009 systematic review, we scored the quality of trial design and found a mean 15.8/26 (standard deviation (SD) 4.3, range 9 to 24/26) which increased with year of publication (Spearman's rho $=0.41, \mathrm{P}<0.01$ ); this represented an improvement of about two points per decade. The total number of patients providing data immediately posttreatment was 4788 at the end of treatment (a mean of 114 per study, SD 71) from the 5424 patients starting treatment (data from 41 of the 42 trials). Mean study completion rate from entry to posttreatment assessment was $87.6 \%$ (SD 9.5\%) and ranged from $65 \%$ to $100 \%$. Overall, the mean number of patients per trial, 114 in this review, was an increase on the mean of 91 in the 2009 review (Eccleston 2009a), although unlike the 2009 review (which included studies with $\mathrm{N}$ between 10 and 19), sample size did not increase with publication date. Women usually outnumbered men, with the average proportion of women per trial being $71 \%$ (SD 21\%, range $4 \%$ to $100 \%$ ). The mean age was 48 (SD 9, range of means from 31 to 82 years), and the mean years of pain (from the 30 studies which provided data) was 8.3 (SD 4.3, range of means from 1.3 to 16.5 years).

Forty-one of the studies specified the source of participants, who were recruited mainly from a range of healthcare settings: 16 studies recruited from pain rehabilitation clinics, one of which supplemented its participants with volunteers; two further studies drew on referrals for pain management and rehabilitation, and one study drew on dental clinic patients and volunteers (46\% studies altogether recruited through pain services). Nine studies recruited from rheumatology clinics, one of which supplemented its participants with volunteers ( $21 \%$ altogether). Seven studies recruited from the community (including one retirement home), with an additional three community recruitment studies adding volunteers $(24 \%$ studies altogether recruited from community sources), and one study recruited entirely through advertisement for volunteers. Two studies took referrals from work-based healthcare services.
Nine studies (21\%) were solely for patients with low back pain, and a further one for low back or neck pain; two were for spinal pain, one for neck and shoulder and one for shoulder alone; eight $(19 \%)$ were for mixed chronic pain patients in which back pain was usually the most common complaint. Seven studies had patient groups with rheumatoid arthritis including one with systemic lupus erythematosus; eight had fibromyalgia; three had temporomandibular joint pain; two had osteoarthritis of the knee.

We classified treatment arms on the basis of their content and of the label given by the authors as cognitive behavioural treatment or as behavioural treatment. All treatment involved a psychologist, trained, or in training and supervised, in delivery. The mean quality of treatment was 5.4/9 (SD 2.3, range 1 to 9) and was unrelated to year of publication (Spearman's rho $=0.20$, nonsignificant). We classified control conditions as 'active control' when there was a protocolised treatment which engaged the patient, such as an exercise programme, a medical procedure, an education programme, a support group or a self instruction booklet, and as 'waiting list or treatment as usual'. We did not distinguish between waiting list and treatment as usual because for some patients treatment as usual is elective treatment which may be none at all and therefore equivalent to being on a waiting list; and some studies allow patients on waiting lists to seek other treatment elsewhere, treatment which may be equivalent to that in 'treatment as usual' conditions. We are aware that this is not an entirely satisfactory classification where treatment as usual involves some active and regular physiotherapy or pharmacotherapy, not dissimilar to those offered in active controls, and where the large majority of patients follow it routinely, but when available information did not allow us to assign this condition to an active control, we classified a condition as treatment as usual.

\section{Excluded studies}

Ninety-three studies did not meet the inclusion criteria and were excluded. Disregarding those which did not primarily concern chronic pain, or which did not appear to be randomised, which were non-inferiority trials, which had too small a number of participants post-treatment, or which were trials of hypnosis or internet interventions, 36 initially appeared to be trials of CBT or behavioural therapy, but on reading the full paper failed our criteria for credible psychological treatment (Abbott 2010; Appelbaum 1988; Astin 2003; Becker 2000; Bendix 1997; Broderick 2004; Brox 2003; Carson 2005; Carson 2010; de Sousa 2009; Dufour 2010; Dworkin 1994; Dworkin 2002a; Dworkin 2002b; Esmer 2010; Fairbank 2005; Fors 2000; Freeman 2002; George 2008; Haugstad 2006; Kapitza 2010; Keller 2004; Kroenke 2009; Lamb 2010; Lambeek 2009; Li 2006; Machado 2007; Moffett 2005; Morone 2009; Rendant 2011; Sahin 2011; Schweikert 2006; Soderlund 2001; Strong 1998; Turner 2011; Wong 2011). While the initial inclusion of these studies from the search is in part evidence of the diversity of terminology used to describe pain and treatments, it also raises important issues about nonspecific or design features which potentially undermine the content or fail to deliver what is implied by the description of treatment, and about the inevitably blurred boundaries between psychological intervention and education, instruction or nonspecific support. This judgement was difficult to apply in some cases and led to extended discussion between the review authors to reach a decision. 


\section{Risk of bias in included studies}

'Risk of bias' is shown in Figure 1 and Figure 2: we used five 'Risk of bias' categories: random sequence generation (selection bias), allocation concealment (selection bias), blinding of outcome assessment (detection bias), incomplete outcome data (attrition bias) and selective reporting (reporting bias). Fifteen studies described a convincing method of randomisation so we judged them to have a low risk of bias, and a further 11 provide an inadequate description so we judged them to be unclear. We judged 16 to have high risk of bias, mainly because the method of randomisation was not described; these were mainly earlier studies. We judged 14 studies to have adequate allocation concealment, one uncertain and 27 high risk, again mainly because there was no description of any procedure designed to do so. Only 12 studies reported attrition fully, including finding no difference between dropouts and completers, and we judged them to have low risk of bias; 19 were unclear risk, mainly because of lack of testing for differences between dropouts and completers, but in some cases because those differences were found; and we judged 11 to have high risk of bias, predominantly because they provided no details of attrition. We judged 34 studies at low risk of bias for selective reporting of outcome since they reported all outcomes, or in one case accounted for those they did not report; we judged one study uncertain because outcomes were combined in factor scores, and seven studies did not report all outcomes which they described in assessment sections of their Methods, and we judged them at high risk of bias. Finally, we judged 13 studies at low risk of bias for outcome assessment since they used blinded assessors; two were unclear; and we judged 27 at high risk of bias since they gave no details of outcome assessment procedures. It should be borne in mind, however, that almost all outcomes were assessed by self report, so that there were restricted opportunities for influencing patients' scores. Thus most judgements of high risk of bias were because of inadequate reporting: we recognise that this is a conservative position and that some studies may have exercised proper precautions in some or all of these areas. 
Figure 1. 'Risk of bias' summary: review authors' judgements about each methodological quality item for each included study.

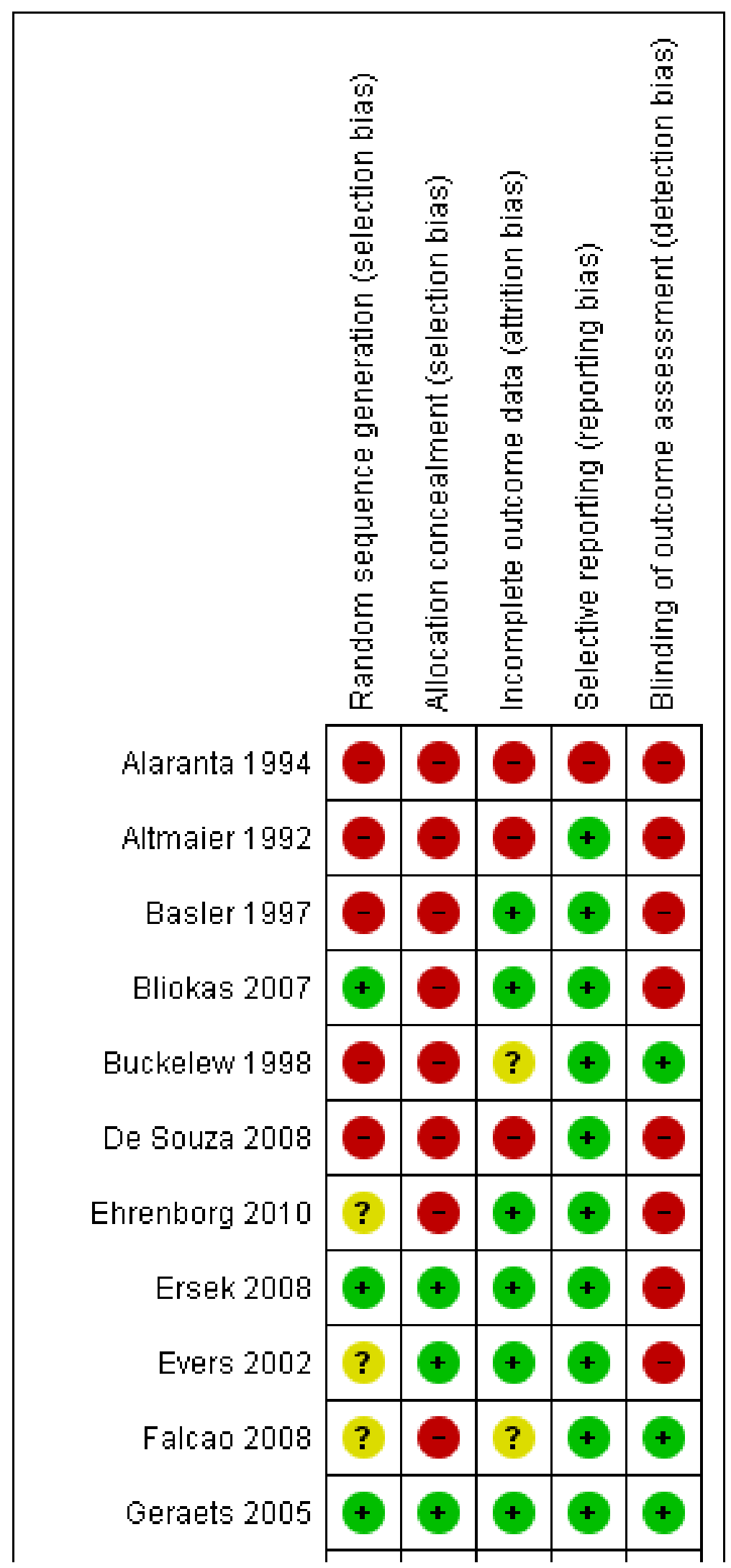

Psychological therapies for the management of chronic pain (excluding headache) in adults (Review) 
Figure 1. (Continued)

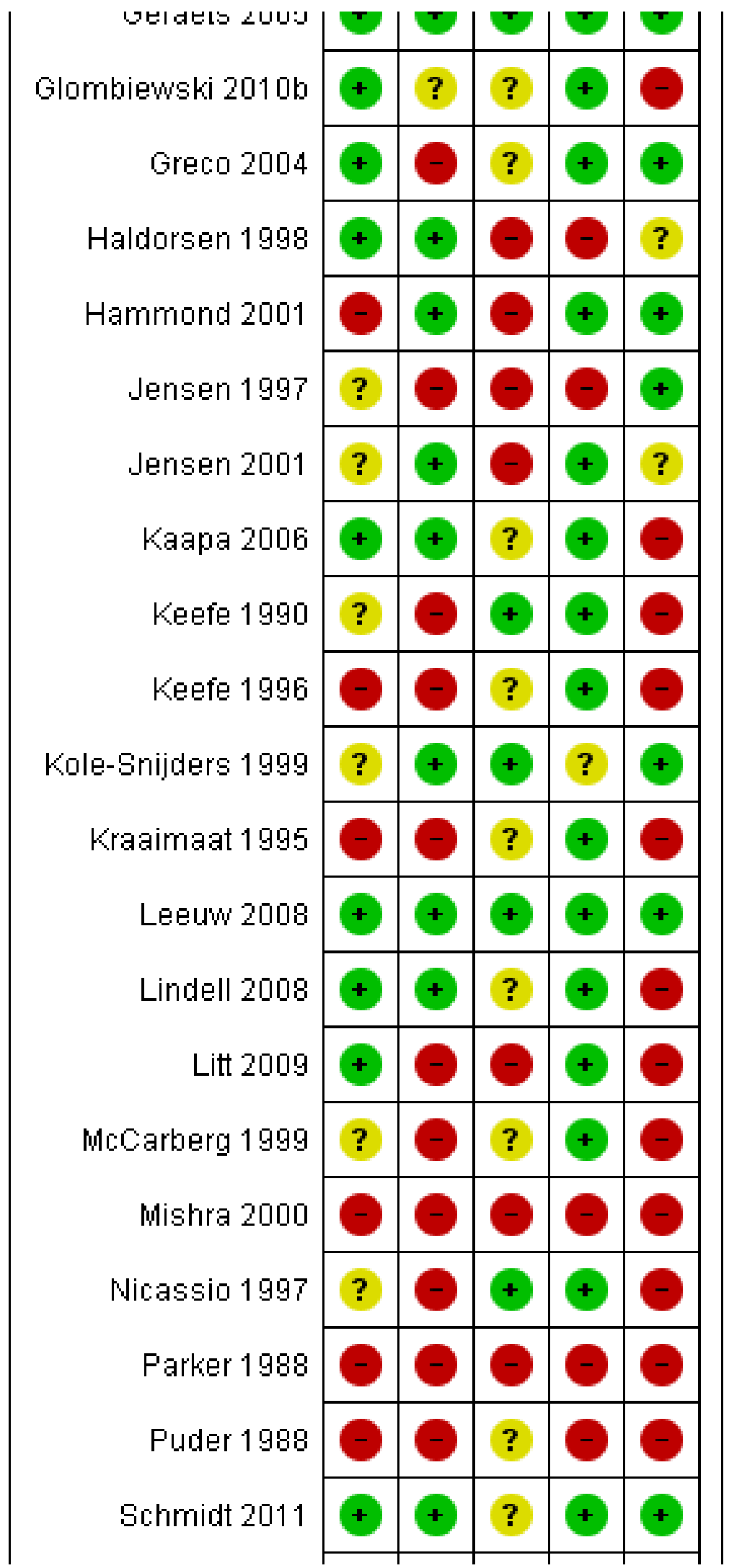

Psychological therapies for the management of chronic pain (excluding headache) in adults (Review) 
Figure 1. (Continued)

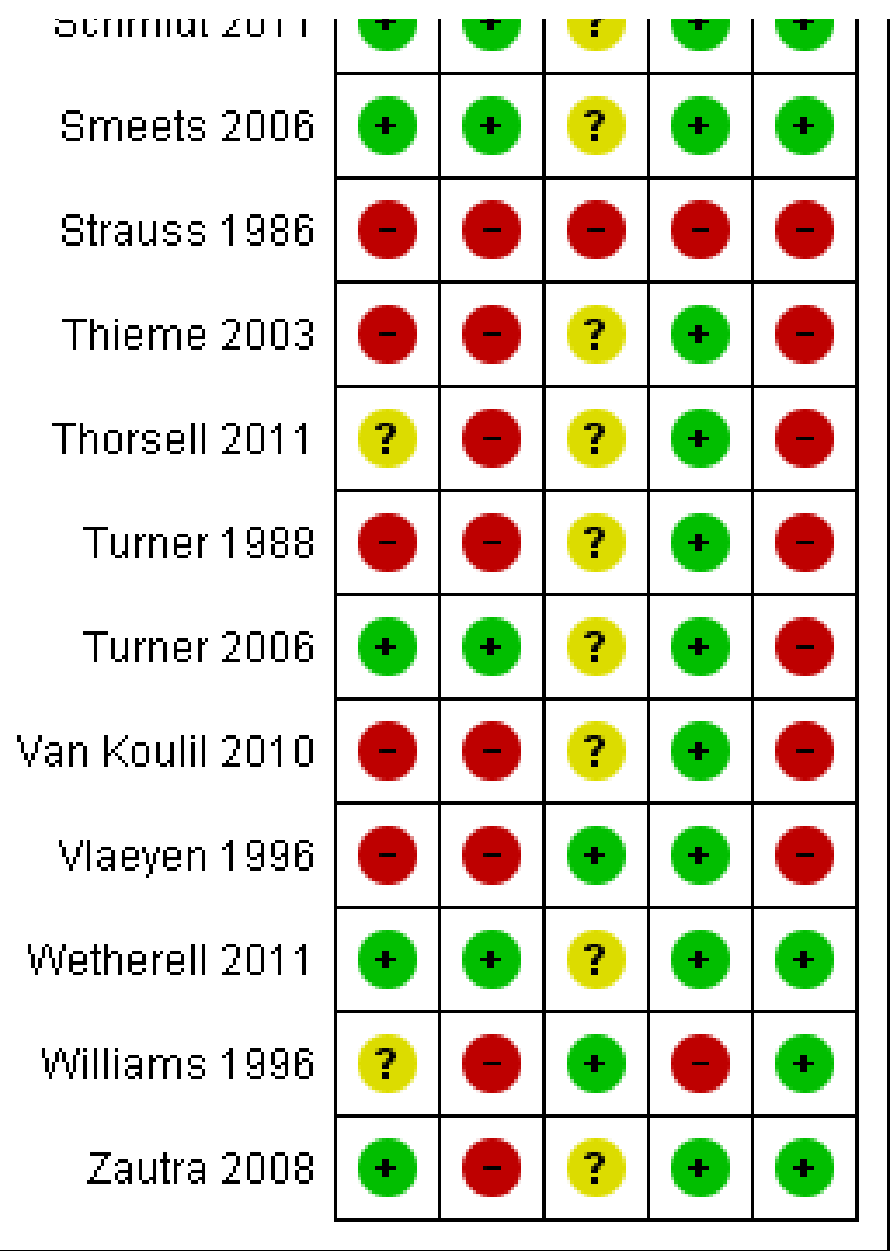

Figure 2. 'Risk of bias' graph: review authors' judgements about each methodological quality item presented as percentages across all included studies.

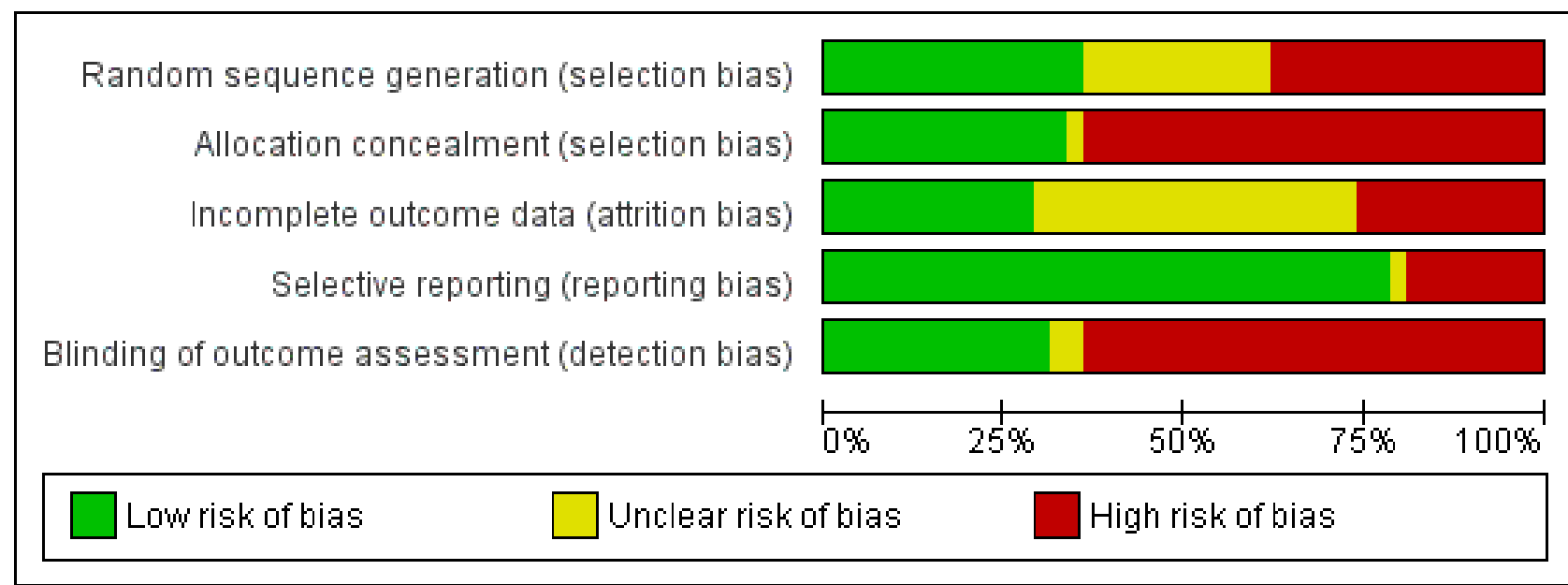

The comprehensive quality assessment scale (Yates 2005) is reported in Characteristics of included studies. For the 42 studies which met the inclusion criteria, the mean overall quality of the studies was 21.2 (SD 5.9, range 10 to 32). The mean design quality score was 15.8 of a possible 26 (SD 4.3, range 9 to 24). A Spearman's correlation to investigate the association between year of study and 
overall quality score showed a weak relationship (rho $=0.37, \mathrm{P}<$ 0.05 ), and between year of study and design quality score a slightly stronger relationship (Spearman's rho $=0.41, P<0.01$ ). Treatment quality was not associated with year of study: see Included studies. $\mathrm{N}$ at the end of treatment was associated with design quality score and with total quality score $(r h o=0.41(P<0.01)$ and 0.38 respectively $(P<0.05))$.

Of the 24 analyses reported (CBT or behaviour therapy versus active control or treatment as usual, post-treatment and follow-up, for 'pain', 'disability', 'mood' and 'catastrophic thinking'), 10 showed low heterogeneity $\left(I^{2} \leq 25 \%\right)$, six showed modest heterogeneity $\left(I^{2}>\right.$ $25 \%$ to $<50 \%$ ) and eight, almost all analyses of behaviour therapy, showed large heterogeneity $\left(I^{2}>=50 \%\right)$.

\section{Effects of interventions}

\section{Cognitive behavioural versus active control post-treatment}

We entered 13 studies with 1258 participants into an analysis of the effects of cognitive behavioural therapy (CBT) on pain compared to active control. The overall effect of $C B T$ on pain was not significant $(Z=1.43, P>0.05)$ (Analysis 1.1). We entered 12 studies with 1130 participants into an analysis of the effects of $C B T$ on disability. The overall effect was significant $(Z=2.66, P<0.01)$ with a small effect size: standardised mean difference (SMD) -0.19 (95\% confidence interval ( $\mathrm{Cl})-0.33$ to -0.05 ) (Analysis 1.2); the $\mathrm{I}^{2}$ value was $25 \%$. We entered 13 studies with 1256 participants into an analysis of the effects of CBT on mood; the overall effect was not significant $(Z=0.72, P>0.05)$ (Analysis 1.3$)$. We entered six studies with 735 participants into an analysis of the effects of CBT on catastrophising; the overall effect of $\mathrm{CBT}$ was just significant: $\mathrm{Z}=$ $1.92, \mathrm{P}=0.05$ (Analysis 1.4). The effect size was SMD $-0.18(95 \% \mathrm{Cl}$ -0.36 to 0.00 ) and the $I^{2}$ value was $31 \%$.

\section{Cognitive behavioural versus active control at follow-up}

We entered 11 studies with 1261 participants into an analysis of the effects of CBT on pain at follow-up. The overall effect of CBT was not significant $(Z=1.12, P>0.05)$ (Analysis 2.1). We entered 12 studies with 1295 participants into an analysis of the effects of CBT on disability at follow-up. The overall effect of CBT at followup was significant $(\mathrm{Z}=2.28, \mathrm{P}<0.05)$ with a small effect size of SMD $-0.15\left(95 \% \mathrm{Cl}-0.28\right.$ to -0.02 ) (Analysis 2.2); the $\mathrm{I}^{2}$ value was $23 \%$. We entered 11 studies with 1261 participants into an analysis of the effects of CBT on mood at follow-up. The overall effect of CBT was not significant $(Z=1.15, P>0.05)$ (Analysis 2.3). We entered two studies with 282 participants into an analysis of the effects of CBT on catastrophising. The overall effect of CBT was not significant: $Z$ $=0.49, \mathrm{P}>0.05$ (Analysis 2.4).

\section{Cognitive behavioural versus treatment as usual post- treatment}

We entered 16 studies with 1148 participants into an analysis of the effects of CBT on pain. The overall effect of CBT was significant $(Z$ $=2.59, \mathrm{P}<0.05)$ with an effect size of SMD $-0.21(95 \% \mathrm{Cl}-0.37$ to -0.05 ) (Analysis 3.1); the $I^{2}$ value was $45 \%$. We entered 15 studies with 1105 participants into an analysis of the effects of CBT on disability. The overall effect was significant $(Z=2.35, P<0.05)$ (Analysis 3.2). The effect size was SMD -0.26 (95\% Cl -0.47 to -0.04$)$; the $I^{2}$ value was $67 \%$. We entered 12 studies with 899 participants into an analysis of the effects of CBT on mood. The overall effect of $C B T$ was significant $(Z=3.84, P<0.01)$ (Analysis 3.3). The effect size was SMD -0.38 ( $95 \% \mathrm{Cl}-0.57$ to -0.18 ); the $\mathrm{I}^{2}$ value was $49 \%$. We entered five studies with 308 participants into an analysis of the effects of CBT on catastrophising. The overall effect of CBT was significant: $Z=4.58, P<0.01$ (Analysis 3.4). The effect size was SMD $-0.53(95 \% \mathrm{Cl}-0.76$ to -0.31$)$ and the $\mathrm{I}^{2}$ value was $0 \%$.

\section{Cognitive behavioural versus treatment as usual at follow-up}

We entered seven studies with 635 participants into an analysis of the effects of CBT on pain at follow-up. The overall effect of CBT was not significant $(Z=0.99, P>0.05)$ (Analysis 4.1). We entered six studies with 450 patients into an analysis of the effects of CBT on disability at follow-up. The overall effect of CBT was not significant $(Z=0.66, P>0.05)$ (Analysis 4.2). We entered seven studies with 637 patients into an analysis of the effects of CBT on mood at follow-up. The overall effect of CBT was just significant $(Z=1.99, P=0.05)$ with a small effect size of SMD $-0.26(95 \% \mathrm{Cl}-0.51$ to 0.00$)$ (Analysis 4.3); the $I^{2}$ value was $58 \%$. There was only one study of 59 participants in the analysis of the effects of CBT on catastrophising. The overall effect of CBT was not significant: $Z=0.84, P>0.05$ (Analysis 4.4).

\section{Behavioural versus active control post-treatment}

There are insufficient studies in this comparison for meta-analysis. One study of 39 participants was analysed for the effects of behaviour therapy on pain. The overall effect of behaviour therapy was not significant $(Z=0.77, P>0.05)$ (Analysis 5.1). We entered two studies of 110 participants into an analysis of the effects of behaviour therapy on disability. The overall effect was not significant $(Z=1.46, P>0.05)$ (Analysis 5.2). There was only one study, with 71 participants, in the analysis of the effects of behaviour therapy on mood (Analysis 5.3), with an effect of behaviour therapy that was just significant $(Z=1.94, P=0.05)$. The effect size was SMD $-0.47(95 \% \mathrm{Cl}-0.94$ to 0.00$)$. We entered two studies with 146 participants into the analysis of the effects of behaviour therapy on catastrophising. The overall effect was not significant: $Z=1.67, P>0.05$ (Analysis 5.4).

\section{Behavioural versus active control at follow-up}

There are insufficient studies in this comparison for meta-analysis. There was only one study with 73 participants in the analysis of the effects of behaviour therapy on pain at follow-up. The overall effect of behaviour therapy was not significant $(Z=0.13, P>0.05)$ (Analysis 6.1). We entered two studies with 144 participants into an analysis of the effects of behaviour therapy on disability at followup. The overall effect of behaviour therapy was not significant $(Z$ $=1.01, \mathrm{P}>0.05$ ) (Analysis 6.2). We entered only one study with 71 participants into the analysis of the effects of behaviour therapy on mood at follow-up. The overall effect of behaviour therapy was not significant $(Z=1.55, P>0.05)$ (Analysis 6.3). We entered one study with 73 participants into the analysis of the effects of behaviour therapy on catastrophising. The overall effect was not significant: $Z$ $=0.25, \mathrm{P}>0.05$ (Analysis 6.4).

\section{Behavioural versus treatment as usual post-treatment}

We entered five studies of 484 participants into an analysis of the effects ofbehaviour therapy on pain. The overall effect of behaviour therapy was not significant $(Z=1.05, P>0.05)$ (Analysis 7.1). We entered five studies of 504 participants into an analysis of the effects of behaviour therapy on disability. The overall effect was not significant $(Z=1.40, P>0.05)$ (Analysis 7.2). We entered three studies of 278 participants into an analysis of the effects of 
behaviour therapy on mood. The overall effect of behaviour therapy was not significant $(Z=1.18, P>0.05)$ (Analysis 7.3). We entered three studies with 269 participants into the analysis of the effects of behaviour therapy on catastrophising. The overall effect was just significant: $Z=1.99, P=0.05$ (Analysis 7.4). The effect size was SMD $-0.72(95 \% \mathrm{Cl}-1.43$ to -0.01$)$, but the $\mathrm{I}^{2}$ value was $84 \%$.

\section{Behavioural versus treatment as usual at follow-up}

We entered two studies with 182 participants into an analysis of the effects of behaviour therapy on pain at follow-up. The overall effect of behaviour therapy was not significant $(Z=0.21, P>0.05)$ (Analysis 8.1). We entered three studies with 336 participants into an analysis of the effects of behaviour therapy on disability at follow-up: the overall effect of behaviour therapy was not significant $(Z=$ $1.08, P>0.05$ ) (Analysis 8.2). We entered two studies with 160 participants into an analysis of the effects of behaviour therapy on mood at follow-up. The overall effect of behaviour therapy was not significant $(Z=0.90, P>0.05)$ (Analysis 8.3 ). No studies provided data on catastrophising at follow-up for this comparison.

\section{Pain outcomes}

CBT appears to have a small effect on pain measured immediately post-treatment when compared with doing nothing (treatment as usual or waiting list), but not when compared with an active control, and there is no effect at follow-up. Behaviour therapy had no effect on pain compared to doing nothing, at either time point; there was only one study in the comparison with an active control, and that showed no benefit post-treatment or at follow-up.

\section{Disability outcomes}

CBT has a small effect on disability post-treatment and at followup, compared with an active control, and post-treatment compared with doing nothing, but this effect disappeared at follow-up. Behaviour therapy had no effect on disability compared to active control or to doing nothing, post-treatment or at follow-up, although there were only two studies comparing behaviour therapy with an active control.

\section{Mood outcomes}

CBT has no effect on mood immediately post-treatment compared with active control but, when compared with doing nothing (treatment as usual or waiting list), it has a moderate effect size immediately post-treatment and a small one at follow-up. Behaviour therapy had only one study in which it was compared with active control, and behaviour therapy showed no effect either post-treatment or at follow-up compared with doing nothing (treatment as usual or waiting list).

\section{Catastrophising outcomes}

CBT had a small effect compared to active control immediately post-treatment, lost at follow-up, but in comparison with doing nothing it had a moderate effect post-treatment which was sustained at follow-up. For behaviour therapy, study numbers were too small in the active control comparison, but in comparison with doing nothing, behaviour therapy had a small effect immediately post-treatment; there were no follow-up data.

\section{Heterogeneity inspection}

In the four analyses showing an effect of intervention over control but with high heterogeneity $\left(I^{2}>50 \%\right)$, we undertook further exploratory analyses. By visual inspection we removed the outliers to test for their influence on the overall effect. In Analysis 3.2, heterogeneity was reduced to $55 \%$ by the removal of one positive outlier (Williams 1996), without affecting the overall significant result. In Analysis 4.2 and Analysis 4.3, removal of a single study (Van Koulil 2010) reduced heterogeneity to $0 \%$ but without changing the non-significant result (Analysis 4.2), and reduced it to 9\% (Analysis 4.3) but also produced a non-significant result in place of the just significant one: $Z$ was $1.57, \mathrm{P}>0.05$. In Analysis 7.4, again removal of a single study (Thieme 2003) reduced heterogeneity to $0 \%$ and strengthened the result, although this was now only produced by two studies: $Z=2.41 \mathrm{P}<0.05$; the effect size was SMD $-0.34(95 \% \mathrm{Cl}$ -0.62 to -0.06$)$.

\section{Effects of quality ratings}

We undertook three further analyses to assess the potential effects of quality. We excluded studies classified as 'high risk' for treatment quality from the analyses. This largely had the effect of increasing CBT effect sizes and reducing heterogeneity, but only in one case did it raise a small effect size to a moderate one: mood change for CBT compared to treatment as usual, post-treatment. There were no effects on behaviour therapy effect sizes where there were sufficient data to analyse. However, use of a compound quality rating scale such as Yates 2005 can be problematic (Cochrane Handbook chapter 8.3.3 (Higgins 2011)); although treatment quality was not associated with post-treatment $\mathrm{N}$ ( $\mathrm{rho}=0.17, \mathrm{P}>0.1$ ), studies of higher quality were already well represented in effect sizes, and analyses are in any case weighted by sample size.

\section{DISCUSSION}

\section{Evidence base}

There is a large evidence base for estimating the effectiveness of psychological treatments in chronic pain. Before applying our new sample size criterion, we found 65 eligible trials, and these in turn came from a larger set which included trials whose psychological content or delivery was insufficient to convince us that the trial was of a genuine psychological treatment. All forms of psychological treatment were reviewed, ranging from well-established techniques such as biofeedback to more recent innovations such as acceptance and commitment therapy (Veehof 2011). Despite our strict criteria on psychological quality and size, we were able to use data from 35 randomised controlled trials (RCTs) (4788 treated participants) of specific behavioural or cognitive behavioural therapy. Cognitive behavioural therapy (CBT) and behaviour therapy dominate the evidence base; there were no trials of other psychological treatments such as psychodynamic or interpersonal psychotherapy, or dialectical behaviour therapy. We excluded the trials of mindfulness where they were based more on physical and meditative techniques than on cognitive or behavioural psychological techniques, and trials of specific methods which we judged fell outside CBT and which are already, at least in part, covered by other systematic reviews: internet intervention for pain (Bender 2011; Macea 2010) and self regulation (in rheumatoid arthritis: Knittle 2010). A systematic review of hypnosis is due given its resurgence as a treatment method (Jensen 2011), albeit aimed more at pain reduction than overall rehabilitation.

This review includes 22 trials from the previous systematic review and 20 new or re-entered trials; seven trials provided no useable 
data. The remainder allowed for reasonable power in the analyses, with the largest analysis being of 1258 participants (CBT versus active control post-treatment) and the smallest of 144 participants (behaviour therapy versus active control at follow-up). An analysis of quality scores, as measured by the Yates et al scale (Yates 2005), showed that the quality of the design and reporting of trials has clearly improved over the years, perhaps as a consequence of the emphasis of Cochrane and other evidence-focused organisations concerned with methodological standards such as CONSORT (Boutron 2008). However, the quality of treatments, of their reporting, or both, does not appear to have improved over time, but the Yates 2005 treatment subscale is restricted to five items so may be relatively insensitive.

\section{Summary of results}

The majority of studies were of $\mathrm{CBT}$, reflecting its dominance in chronic pain management and in psychological treatment more widely. Of the eight comparisons of CBT versus active control (four outcomes: pain, disability, mood, catastrophic thinking, at two time points, immediately post-treatment and six to 12 months followup), three were positive: disability immediately post-treatment and at follow-up, and catastrophic thinking post-treatment. There were stronger effects for the seven comparisons of CBT versus doing nothing (treatment as usual or waiting list) for four outcomes: small effects on pain and on disability post-treatment but not at followup; small effects on mood maintained at follow-up; and moderate effects on catastrophising with insufficient data to analyse at follow-up.

For behaviour therapy the evidence is much weaker and, with our more stringent criteria, rather sparse. Behaviour therapy was developed in the 1960s and 1970s and evaluated as part of the first wave of psychological treatment for pain (Morley 2011). As a consequence, trials tended to be small and methodologically weak and have been largely superseded by procedures that claim to be cognitive behavioural. Compared with doing nothing (treatment as usual or waiting list), behaviour therapy has no effects on pain, disability or mood immediately post-treatment, but a small effect on catastrophic thinking; there were insufficient data at follow-up except for disability, where there was no effect.

The size of effects - small to moderate - is similar to other systematic reviews in this field: of mixed chronic pain (Scascighini 2008), low back pain (Henschke 2010a; Hoffman 2007), fibromyalgia (Bernady 2010; Glombiewski 2010; Häuser 2009) and arthritis (Dixon 2007). It is also comparable with effect sizes of CBT for pain problems in children (Eccleston 2009b) and for major psychological disorders (Butler 2006). Of our four outcome domains, effects on mood (mostly depression) were strongest, followed by catastrophic thinking, disability and, lastly, pain. We did not include reduction in health care use (but see Bernady 2010), or cost-effectiveness (see Gatchel 2006).

\section{Change in evidence from previous review}

We raised the quality criterion for $\mathrm{N}$ (sample size) in this review, bearing in mind the risk of bias of small numbers in trials (Nuesch 2009), and the overall tendency for poorer quality trials to produce more positive results (Furlan 2001; loannidis 2005; Nuesch 2009). Numbers in trials have steadily increased over time, but in some cases this appears to be at the cost of treatment intensity (for instance, number of hours of patient contact, or staff experience).
Compared to our 2009 review (Eccleston 2009a), the effect sizes for CBT are largely sustained and extended with the addition of catastrophic thinking as an outcome, while those for behaviour therapy are diminished. Treatment gains are of the same order as those of other available treatments (Glombiewski 2010), as shown by head-to-head trials of surgery versus psychologically based rehabilitation (Fairbank 2005; Hellum 2011).

\section{Issues for consideration}

Psychological therapies for the management of chronic pain are potentially useful treatments, with better evidence for and better effects of CBT than behaviour therapy. There are, however, many problems in interpreting the data and using it to devise a strategy to improve our understanding. We discuss the most important issues, or those that particularly affect psychological treatments, below, and then discuss what we should do next as a research community instead of simply continuing to conduct small RCTs and systematically reviewing them.

1. The lack of coherent theory underlying many of these studies remains a concern. We do not have a clear notion of the mechanisms of change in CBT trials (pace Jensen 2011), nor are we yet able to distinguish well between specific effects of therapy and nonspecific effects of the interactions and context, an unresolved issue in psychology more broadly (Roth 2005). A simple model of independent deficits in cognition, emotion or physical function to be remedied by independent components of therapy is inadequate; even assumptions of deconditioning and poor physical status in chronic pain have proved to be unsubstantiated (Lin 2011; Verbunt 2010). Change in some outcomes may be needed to facilitate change in others: it is common to assume or to hypothesise that change in beliefs and ways of thinking (such as catastrophising) mediates other changes (Moss-Morris 2007; Thorn Burns 2011), and this will not be tested by RCTs or post hoc data analyses (even in very large trials: Underwood 2011) but by carefully designed prospective studies (Wideman 2009) and experimental analysis of specific treatment components (e.g. Vlaeyen de Jong 2001).

2. There are particular issues of bias and potential bias in trials which affect interpretation of results and conclusions to be drawn from them. These can be described under the headings of patient factors, treatment factors and methodological issues.

2.1. Patient samples are heterogeneous (Turk Okifuji 2002) and, without a suitable theory, our attempts to subgroup them are either based on non-psychological properties, such as diagnosis, or on superficial, non-functional characteristics which can be elicited by questionnaire. Neither strategy is likely to be helpful in identifying what works for whom. A more psychologically informed subgrouping of patients, rather than by diagnostic group, should allow better targeted and more effective treatment (Morley 2006). Matching patients to treatment components according to baseline problem severity misses the demonstrated impact of, for instance, the behavioural component on emotional problems, or the cognitive component on physical activity. Treatment makes substantial demands on patients, although many trials do not monitor whether patients practise treatment components as instructed. Treatment aims to enable long-term changes in behaviour related to pain, but a test of adherence in the month following intensive $\mathrm{CBT}$ to cognitive, exercise and activity plans showed only $2 \%$ to $3 \%$ of variance in outcomes explained by adherence (Curran 2009). While assessment of adherence could 
doubtless be improved, we strongly suspect that the model of adherence is too simple, failing to look beyond the patient and to acknowledge substantial obstacles wholly or partly outside the patient's control (Nicholas 2010).

2.2. Treatments are similarly heterogenous, and the procedures included in treatment arms of many of the trials reviewed are pragmatic mixes of various content, often without an adequate rationale, and with apparent disjunction between stated aims of treatment, actual treatment content and outcomes measured. Component dismantling studies offer an illusion of identifying 'active ingredients' of the total package when we do not yet have the power of numbers, nor the statistics, to calculate the effects of each component on each outcome (Grimshaw 1995). Treatment content is difficult to represent even given the possibility of extended accounts on internet appendices (Thorn 2007); and, although it is possible to measure treatment fidelity (Leeuw Goossens 2008), we still do not know whether the unique components of therapy are the important ones. The heterogeneity indices give reason to suspect that there are important differences between treatments of potential interest that have yet to be identified. Treatment content, even with the most detailed protocol, will differ in the hands of different therapists with greater or lesser skills at eliciting and working with examples of emotional and practical importance for patients rather than talking in general terms about change, a particular issue of concern with less experienced therapists (Waller 2009). Then any psychological treatment has to be, as it were, manufactured in the moment it is delivered. In this way psychological therapies are comparable with surgery, rather than with pharmacotherapy.

2.3. There are further particular methodological issues of note. In particular, patients presenting with multiple problems captured by the label of chronic pain, treated with multicomponent, often programmatic, treatments, unsurprisingly make many changes which may or may not be captured by outcome measures. Neither patients nor trial authors agree on the relative importance of all targets of treatment (Beale 2011; Turk 2008). Further, outcomes are analysed as if independent, although they are unlikely to be so. In a few cases this has been empirically demonstrated: depression and physical disability tend to be associated in chronic pain, independent of measurement contamination (Alschuler 2008). While standard reporting (Brown Brunnhuber 2006; Garratt 2008; Thorn 2007) would help to some extent, the problem lies in the lack of adequate models to guide intervention. The field should seriously consider developing measures which are capable of indexing clinical improvement to replace or augment statistical change (Morley 2006) and which have ecological validity. Broad spectrum measures of the disability domain, such as quality of life (e.g. Short Form 36 Health Survey) may have validity problems when applied to trials of the effectiveness of therapies, caused largely by the inclusion of content either irrelevant to the patient, not the target of treatment, or both (Bowling 1997; Dworkin 2005). As a consequence, the sensitivity of measures may be compromised. Additionally, trials report results in terms of statistical rather than clinical significance, which may have led to earlier optimistic summaries of effectiveness. Binary outcomes based on a clinical significance criteria (Morley 2006; Morley 2008) would allow us to estimate treatment responders (Dworkin 2005; Dworkin 2008): people who are 'successfully' treated by CBT or behaviour therapy, and to estimate adverse events, the lack of attention to which is deplorable. We note that a recent study of effectiveness observed evidence of deterioration in a small proportion of patients using statistically defined criteria for clinically significant change (Morley 2008).

3. A further methodological issue is the design of control groups. Relatively few trials in this review used 'attention control' structurally equivalent to the active treatment, with the explicit aim of minimising differences between conditions in such nonspecific effects, and our separation of comparisons of active comparators from treatment as usual or waiting list does not match the category of attention control. Particularly in studies that compare mean data from continuous measures (Hrobarjtsson 2001; Hrobarjtsson 2004), this leaves uncertainty about whether the benefits of treatment can be attributed to specific features of treatment. This is not unique to psychological studies but it is relatively rare for it to be acknowledged in studies of physical or drug interventions (Wren 2011, yoga review). We strongly suspect that as a field we have underestimated the complexity of behaviour change and the social and psychological influences that maintain disability in chronic pain patients (Blyth 2007). Further, the typical chronic pain patient has well-established behavioural patterns reinforced over a long period of failed attempted adjustment to pain and distress, and it has not been established whether the psychotherapeutic content of existing trials is adequate; the current review cannot resolve that question. While it is possible, and we plan, to perform sub-analyses for various aspects of treatment, such as treatment intensity or quantity (associated with outcome by several other systematic reviews: Scascighini 2008, Glombiewski 2010 and in psychological treatments in general, e.g. Barkham 2006), those aspects of treatment such as treatment content, quantity (dose), staff competence and patient population are not independent of each other in their effects on outcome. We speculate, however, that good clinical outcomes should perhaps not be expected from dilute and brief treatments delivered by inexperienced staff to severely distressed patients, particularly given the poor preparation and access to specialist care identified in primary care studies (Breivik 2006; Gatchel 2006; Somerville 2008).

4. We know that the effects of drugs in chronic pain tend to be either very good or very poor. Response is bimodal, with small numbers of responders, often as little as $5 \%$ to $20 \%$ more than with placebo drug (Moore 2010). It may well be that psychological intervention has a similar type of response, with a small number of patients making substantial changes but most changing little, making trials and meta-analyses relatively insensitive. This review has used average scores because average scores are reported in trials. It is arguably more relevant to analyse data by the number of individual patients achieving a level of longer-term improvement in pain, disability, distress or other problem; a level set with reference to clinical meaning. In some chronic pain conditions which are difficult to treat, like fibromyalgia or chronic low back pain, the proportion of patients benefiting from drug treatment is small. Similar low success rates are likely for psychological interventions, especially in populations in which many previous treatments have failed.

\section{AUTHORS' CONCLUSIONS}

\section{Implications for practice}

Psychological interventions can reduce pain, disability, psychological distress and catastrophic ways of thinking about pain. Average effect sizes derived from collapsing data across 
trials are relatively small, as they are across pharmacological and physical treatments for chronic pain. Examination of what we think is feasible as the outcome of psychological treatment is appropriate: is it mere palliation, in which case effects will be small, or do we expect to move people who are stuck in trying to solve the unsolvable problem of pain to address instead the solvable problem of living more satisfactorily with chronic pain (Eccleston 2007), and starting to do so? Or to put it another way, do we believe that we effectively enable patients to manage the interruption of pain and to reduce its interference with their lives, and thereby to repair damaged identities (Morley 2011). These are substantial changes, unlikely to occur rapidly (within the timescale of some trials). What is evident from this review is the following:

1. CBT is effective when delivered by experienced staff, those trained and supervised in the trial protocol, or both. The results cannot be extrapolated to CBT delivered by untrained staff.

2. There is no clear benefit of adding further components to multicomponent CBT: it is unlikely that the extra component, such as two sessions on 'mindfulness', will make any measurable difference. The rationale given for such additions in trials in this review was often weak.

3. Although trials do not tend to report adverse effects or deterioration (such as worsening of depression to a level of clinical concern), we know that such effects should be small (Fairbank 2005; Hellum 2011; Morley 2008), so the treatment can be considered to be safe, with the reservation that the reasons for discontinuing treatment are rarely given and may be due to hidden adverse effects.

4. Average effects mask larger changes on the part of some patients and little or none for others. Better trial design and observational studies will help us to identify those patients for whom CBT can enable substantially better outcomes, and those who need current treatment to be adapted or who need other treatment to improve their quality of life with chronic pain. Clinicians can contribute significantly to generating hypotheses about how to distinguish these patients from one another.

5. The way forward for psychological treatment lies not in more RCTs, unless the intervention is entirely novel, the patient population has not previously been studied, or the outcomes are truly innovative. Any new RCT needs to be designed and reported taking explicit account of the challenges identified and discussed in this review.

\section{Implications for research}

1. We recommend the immediate cessation of new RCTs of CBT against simple alternatives, unless a strong case can be given for the novelty of the population or treatment under investigation. We include in this recommendation treatments of CBT with additional components: see Implications for practice, point 2 . The evidence of weak to moderate effects across a range of outcomes is clear from our systematic reviews and from the others cited above, and is very unlikely to change as a result of further similar RCTs and systematic reviews. The average effects are small, as they are for all treatments of chronic pain (Moore 2010).

2. The question addressed by psychological treatment for chronic pain is complex, conceptually and statistically. We no longer believe that it is possible to design a 'pure' trial of a single component of intervention (such as relaxation, operant reinforcement or acceptance), although that is not to deny that there is much to be learned from some of the trials which attempt it in this review. Suggested solutions in realistic and clinically informed evaluations of complex packages (Craig 2008; Shepperd 2009) will take us no further than the current review and, with pressure to economise on resources, there is so far no indication of which components should be cut or retained.

3. Since we share these challenges with the larger field of pain medicine, we can usefully consider some current initiatives: running $\mathrm{N}$ of 1 trials (McMillan 2010); examining individual data for response trajectories (Lambert 2001; Moore 2005); pooling data for responder analyses (Moore 2010); or conducting clinical effectiveness trials (Moore 2010), where 'clinical effectiveness' is "the product of efficacy, tolerability, utility, cost, and speed" (Moore 2010, p174) so that trials focus on maximising benefit and minimising cost, including adverse events.

4. We need better theory to generate hypotheses about processes and mechanisms of change, to be tested in terms of populations, treatment content, treatment process and outcomes.

\section{ACKNOWLEDGEMENTS}

We thank Malcolm Adams and Shona Yates for earlier contributions to the protocol, in particular for discussion on coding. We thank Leslie Hearn for help with data extraction from trials and proofreading, and lain Edgley for data extraction for catastrophic thinking. We are also grateful to the Cochrane Pain, Palliative and Supportive Care (PaPaS) review group and to the referees for their detailed and helpful feedback. 


\section{R E F E R E N C E S}

\section{References to studies included in this review}

Alaranta 1994 \{published data only\}

Alaranta H, Rytokoski U, Rissanen A, Talo S, Ronnemaa T, Puukka $P$, et al. Intensive physical and psychosocial training program for patients with chronic low back pain. A controlled clinical trial. Spine 1994;19:1339-49.

\section{Altmaier 1992 \{published data only\}}

Altmaier EM, Lehmann TR, Russell DW, Weinstein JN, Kao CF. The effectiveness of psychological interventions for the rehabilitation of low back pain: a randomized controlled trial evaluation. Pain 1992;49:329-35.

\section{Basler 1997 \{published data only\}}

Basler HD, Jakle C, Kroner-Herwig B. Incorporation of cognitivebehavioral treatment into the medical care of chronic low back patients: a controlled randomized study in German pain treatment centers. Patient Education \& Counseling 1997;31:113-24.

\section{Bliokas 2007 \{published data only\}}

Bliokas VV, Cartmill TK, Nagy BJ. Does systematic graded exposure in vivo enhance outcomes in multidisciplinary chronic pain management groups?. Clinical Journal of Pain 2007;23:361-74.

\section{Buckelew 1998 \{published data only\}}

Buckelew SP, Conway R, Parker J, Deuser WE, Read J, Witty TE, et al. Biofeedback/relaxation training and exercise interventions for fibromyalgia: a prospective trial. Arthritis Care and Research 1998;11:196-209.

\section{De Souza 2008 \{published data only\}}

De Souza JB, Bourgault P, Charest J, Marchand S. Interactional School of Fibromyalgia: learning to cope with pain - a randomized controlled study [Escola Inter-relacional de Fibromialgia: aprendendo a lidar com a dor - estudo clinico randomizado]. Revista Brasileira de Reumatologia 2008;48:218-25.

\section{Ehrenborg 2010 \{published data only\}}

Ehrenborg C, Archenholtz B. Is surface EMG biofeedback an effective training method for persons with neck and shoulder complaints after whiplash-associated disorders concerning activities of daily living and pain - a randomized controlled trial. Clinical Rehabilitation 2010;24:715-26.

\section{Ersek 2008 \{published data only}

Ersek M, Turner JA, Cain KC, Kemp CA. Results of a randomized controlled trial to examine the efficacy of a chronic pain selfmanagement group for older adults [ISRCTN11899548]. Pain 2008;138:29-40.

\section{Evers 2002 \{published data only\}}

Evers AW, Kraaimaat FW, van Riel PL, de Jong AJ. Tailored cognitive-behavioral therapy in early rheumatoid arthritis for patients at risk: a randomized controlled trial. Pain 2002;100:141-53.
Falcao 2008 \{published data only\}

Falcão DM, Sales L, Leite JR, Feldman D, Valim V, Natour J. Cognitive behavioral therapy for the treatment of fibromyalgia syndrome: a randomized controlled trial. Journal of Musculoskeletal Pain 2008;16:133-40.

\section{Geraets 2005 \{published data only\}}

Geraets J, Goossens M, De Bruijn CPC, De Groot IJM, Koke AJS, Pelt R, et al. Cost-effectiveness of a graded exercise therapy program for patients with chronic shoulder complaints. International Journal of Technology Assessment in Health Care 2006;22:76-83.

Geraets J, Goossens M, de Groot IJM, de Bruijn CPC, de Bie RA, Dinant GJ, et al. Effectiveness of a graded exercise therapy program for patients with chronic shoulder complaints. Australian Journal of Physiotherapy 2005;51:87-94.

* Geraets JJ, Goossens ME de Bruijn CP, Koke AJ, de Bie RA, Pelt RAGB, et al. A behavioural treatment for chronic shoulder complaints: concepts, development, and study design. Australian Journal of Physiotherapy 2005;50:33-8.

\section{Glombiewski 2010b \{published data only\}}

Glombiewski JA, Hartwich-Tersek J, Rief W. Two psychological interventions are effective in severely disabled, chronic back pain patients: a randomised controlled trial. International Journal of Behavioral Medicine 2009;17:97-107.

Greco 2004 \{published data only\}

Greco CM, Rudy TE, Manzi S. Effects of a stress-reduction program on psychological function, pain, and physical function of systemic lupus erythematosus patients: a randomized controlled trial. Arthritis and Rheumatism 2004;51:625-34.

Haldorsen 1998 \{published data only\}

Haldorsen EM, Kronholm K, Skouen JS, Ursin H. Multimodal cognitive behavioral treatment of patients sicklisted for musculoskeletal pain: a randomized controlled study. Scandinavian Journal of Rheumatology 1998;27:16-25.

Hammond 2001 \{published data only\}

* Hammond A, Freeman K. One-year outcomes of a randomized controlled trial of an educational-behavioural joint protection programme for people with rheumatoid arthritis. Rheumatology 2001;40:1044-51.

Hammond A, Freeman K. The long-term outcomes from a randomized controlled trial of an educational-behavioural joint protection programme for people with rheumatoid arthritis. Clinical Rehabilitation 2004;18:520-8.

\section{Jensen 1997 \{published data only\}}

Jensen IB, Bergstrom G, Ljungquist T, Bodin L. A 3-year followup of a multidisciplinary rehabilitation programme for back and neck pain. Pain 2005;115:273-83. 
Jensen 2001 \{published data only\}

* Jensen IB, Bergstroem G, Ljungquist T, Bodin L, Nygren AL. A randomized controlled component analysis of a behavioral medicine rehabilitation program for chronic spinal pain: are the effects dependent on gender?. Pain 2001;91:65-78.

Jensen IB, Bergstrom G, Ljungquist T, Bodin L. A 3-year followup of a multidisciplinary rehabilitation programme for back and neck pain. Pain 2005;115:273-83.

\section{Kaapa 2006 \{published data only\}}

Kaapa EH, Frantsi K, Sarna S, Malmivaara A. Multidisciplinary group rehabilitation versus individual physiotherapy for chronic nonspecific low back pain: a randomized trial. Spine 2006;31:371-6.

\section{Keefe 1990 \{published data only\}}

Keefe FJ, Caldwell DS, Williams DA, Gil KM, Mitchell D, Robertson $\mathrm{C}$, et al. Pain coping skills training in the management of osteoarthritic knee pain: II. Follow-up results. Behavior Therapy 1990;21:435-47.

* Keefe FJ, Caldwell DS, Williams DA, Gil KM, Mitchell D, Robertson $\mathrm{C}$, et al. Pain coping skills training in the management of osteoarthritic knee pain: a comparative study. Behavior Therapy 1990;21:49-62.

\section{Keefe 1996 \{published data only\}}

Keefe FJ, Caldwell DS, Baucom D, Salley A, Robinson E, Timmons K, et al. Spouse-assisted coping skills training in the management of knee pain in osteoarthritis: long-term follow up results. Pain 1999;12:49-62.

* Keefe FJ, Caldwell DS, Baucom D, Salley A, Robinson E, Timmons K, et al. Spouse-assisted coping skills training in the management of osteoarthritic knee pain. Arthritis Care and Research 1996;9:279-91.

\section{Kole-Snijders 1999 \{published data only\}}

Kole-Snijders AM, Vlaeyen JW, Goossens ME, Rutten-van Moelken MP, Heuts PH, van Breukelen G, et al. Chronic low-back pain: what does cognitive coping skills training add to operant behavioral treatment? Results of a randomized clinical trial. Journal of Consulting and Clinical Psychology 1999;67:931-44.

Spinhoven P, ter Kuile M, Kole-Snijders AMJ, Mansfield MH, den Ouden D-J, Vlaeyen JWS. Catastrophizing and internal pain control as mediators of outcome in the multidisciplinary treatment of chronic low back pain. European Journal of Pain 2004:8:211-9.

\section{Kraaimaat 1995 \{published data only\}}

Kraaimaat FW, Brons MR, Geenen R, Bijlsma JWJ. The effect of cognitive behavior therapy in patients with rheumatoid arthritis. Behaviour Research and Therapy 1995;33:487-95.

\section{Leeuw 2008 \{published data only\}}

Leeus M, Goossens MEJB, van Breukelen GJP, de Jong JR, Heuts PHTG, Smeets RJEM, et al. Exposure in vivo versus operant graded activity in chronic low back pain patients: results of a randomized controlled trial. Pain 2008;138(1):192-207.

\section{Lindell 2008 \{published data only\}}

Lindell O, Johansson S-E, Strender L-E. Subacute and chronic, non-specific back and neck pain: cognitive-behavioural rehabilitation versus primary care. A randomized controlled trial. BMC Musculoskeletal Disorders 2008;9:172-89.

Litt 2009 \{published data only\}

Litt MD, Shafer DM, Ibanez CR, Kreutzer DL, Tawfik-Yonkers Z. Momentary pain and coping in temporomandibular disorder pain: exploring mechanisms of cognitive behavioral treatment for chronic pain. Pain 2009;145:160-8.

McCarberg 1999 \{published data only\}

McCarberg B, Wolf J. Chronic pain management in a health maintenance organization. Clinical Journal of Pain 1999;15:50-7.

Mishra 2000 \{published data only\}

Mishra KD, Gatchel RJ, Gardea MA. The relative efficacy of three cognitive-behavioral treatment approaches to temporomandibular disorders. Journal of Behavioral Medicine 2000;23:293-309.

\section{Nicassio 1997 \{published data only\}}

Nicassio PM, Radojevic V, Weisman MH, Schuman C, Kim J, Schoenfeld-Smith $\mathrm{K}$, et al. A comparison of behavioral and educational interventions for fibromyalgia. Journal of Rheumatology 1997;24:2000-7.

Parker 1988 \{published data only\}

Parker JC, Frank RG, Beck NC, Smarr KL, Buesher KL, Phillips LR, et al. Pain management in rheumatoid arthritis patients. A cognitive behavioural approach. Arthritis and Rheumatism 1988;31:593-601.

Puder 1988 \{published data only\}

Puder RS. Age analysis of cognitive-behavioral group therapy for chronic pain outpatients. Psychology and Aging 1988;3:204-7.

\section{Schmidt 2011 \{published data only\}}

Schmidt S, Grossman P, Schwarzer B, Jena S, Naumann J, Walach $\mathrm{H}$. Treating fibromyalgia with mindfulness-based stress reduction: results from a 3-armed randomized controlled trial. Pain 2011:152:361-9.

\section{Smeets 2006 \{published data only\}}

* Smeets R, Vlaeyen JWS, Hidding A, Kester ADM, Van Der Heijden G, Van Geel ACM, et al. Active rehabilitation for chronic low back pain: cognitive-behavioral, physical, or both? First direct post-treatment results from a randomized controlled trial. BMC Musculoskeletal Disorders 2006;7:1-16.

Smeets R, Vlaeyen JWS, Kester ADM, Knottnerus JA. Reduction of pain catastrophizing mediates the outcome of both physical and cognitive-behavioral treatment in chronic low back pain. Journal of Pain 2006;7:261-71.

Smeets RJEM, Vlaeyen JWS, Hidding A, Kester ADM, van der Heijden GJMG, Knottnerus JA. Chronic low back pain: physical training, graded activity with problem solving training, 
or both? The one-year post-treatment results of a randomized controlled trial. Pain 2008;134:263-76.

\section{Strauss 1986 \{published data only\}}

Strauss GD, Spiegel JS, Daniels M, Speigel T, Landsverk J, Roy-Byne P, et al. Group therapies for rheumatoid arthritis. A controlled study of two approaches. Arthritis and Rheumatism 1986;29(10):1203-9.

\section{Thieme 2003 \{published data only\}}

Thieme K, Gromnica-Ihle E, Flor H. Operant behavioral treatment of fibromyalgia: a controlled study. Arthritis and Rheumatism 2003;49:314-20.

\section{Thorsell 2011 \{published data only\}}

Thorsell J, Finnes A, Dahl J, Lundgren T, Gybrant M, Gordh T, et al. A comparative study of two manual-based self-help interventions, acceptance and commitment therapy and applied relaxation, for persons with chronic pain. Clinical Journal of Pain 2011;27:716-23.

\section{Turner 1988 \{published data only\}}

Turner JA, Clancy S. Comparison of operant behavioral and cognitive-behavioral group treatment for chronic low back pain. Journal of Consulting \& Clinical Psychology 1988;56:261-6.

\section{Turner 2006 \{published data only\}}

Turner JA, Mancl L, Aaron LA. Short- and long-term efficacy of brief cognitive-behavioral therapy for patients with chronic temporomandibular disorder pain: a randomized, controlled trial. Pain 2006;121:181-94.

\section{Van Koulil 2010 \{published data only\}}

Van Koulil S, Van Lankveld W, Kraaimaat FW, Van Helmond T, Vedder A, Van Hoorn H, et al. Tailored cognitive-behavioral therapy and exercise training for high-risk patients with fibromyalgia. Arthritis Care and Research 2010;62:1377-85.

\section{Vlaeyen 1996 \{published data only\}}

Vlaeyen JW, Teeken-Gruben NJ, Goossens ME, Rutten-van Molken MP, Pelt RA, van Eek $\mathrm{H}$, et al. Cognitive-educational treatment of fibromyalgia: a randomized clinical trial. I. Clinical effects. Journal of Rheumatology 1996;23:1237-45.

\section{Wetherell 2011 \{published data only\}}

Wetherell JL, Afari N, Rutledge T, Sorrell JT, Stoddard JA, Petkus AJ, et al. A randomized, controlled trial of acceptance and commitment therapy and cognitive-behavioral therapy for chronic pain. Pain 2011;152:2098-107.

\section{Williams 1996 \{published data only\}}

Williams A, Richardson P, Nicholas M, Pither C, Harding VR, Ridout KL, et al. Inpatient vs. outpatient pain management: results of a randomised controlled trial. Pain 1996;66:13-22.

\section{Zautra 2008 \{published data only\}}

Zautra AJ, Davis MC, Reich JW, Nicassio P, Tennen H, Finan P, et al. Comparison of cognitive behavioral and mindfulness meditation interventions on adaptation to rheumatoid arthritis for patients with and without history of recurrent depression. Journal of Consulting and Clinical Psychology 2008;76:408-21.

\section{References to studies excluded from this review}

Abbott 2010 \{published data only\}

Abbott AD, Tyni-Lenne R, Hedlund R. Early rehabilitation targeting cognition, behavior, and motor function after lumbar fusion: a randomized controlled trial. Spine 2010;35(8):845-57.

\section{Abrahamsen 2008 \{published data only\}}

Abrahamsen R, Baad-Hansen L, Svensson P. Hypnosis in the management of persistent idiopathic orofacial pain - clinical and psychosocial findings. Pain 2008;136:44-52.

\section{Appelbaum 1988 \{published data only\}}

Appelbaum KA, Blanchard EB, Hickling EJ, Alfonso M. Cognitive behavioral treatment of a veteran population with moderate to severe rheumatoid arthritis. Behavior Therapy 1988;19:489-502.

Asenlof 2005 \{published data only\}

Asenlof P, Denison E, Lindberg P. Individually tailored treatment targeting activity, motor behavior, and cognition reduces painrelated disability: a randomized controlled trial in patients with musculoskeletal pain. Journal of Pain 2005;6:588-603.

\section{Astin 2003 \{published data only\}}

Astin JA, Berman BM, Bausell B, Lee WL, Hochberg M, Forys KL. The efficacy of mindfulness meditation plus Qigong movement therapy in the treatment of fibromyalgia: a randomized controlled trial. Journal of Rheumatology 2003;30:2257-62.

\section{Babu 2007 \{published data only\}}

Babu AS, Mathew E, Danda D, Prakesh H. Management of patients with fibromyalgia using biofeedback: a randomized control trial. Indian Journal of Medical Sciences 2007;61:445-61.

\section{Becker 2000 \{published data only\}}

Becker N, Sjogren P, Bech P, Olsen AK, Eriksen J. Treatment outcome of chronic non-malignant pain patients managed in a Danish multidisciplinary pain centre compared to general practice: a randomised controlled trial. Pain 2000;84:203-11.

\section{Bendix 1997 \{published data only\}}

Bendix A, Bendix T, Lund C, Kirkbak S, Ostenfeld S. Comparison of three intensive programs for chronic low back pain patients. A prospective, randomized, observer-blinded study with oneyear follow-up. Scandinavian Journal of Rehabilitation Medicine 1997;29:81-9.

\section{Bradley 1987 \{published data only\}}

Bradley LA, Young LD, Anderson KO, Turner RA, Agudelo CA, McDaniel LK, et al. Effects of psychological therapy on pain behavior of rheumatoid arthritis patients. Treatment outcome and six-month follow up. Arthritis and Rheumatism 1987;30:1105-14.

\section{Broderick 2004 \{published data only\}}

Broderick JE, Stone AA, Smyth JM, Kaell AT. The feasibility and effectiveness of an expressive writing intervention for rheumatoid arthritis via home-based videotaped instructions. Annals of Behavioral Medicine 2004;27:50-9. 


\section{Brox 2003 \{published data only\}}

Brox J, Sorensen I, Friis R, Nygaard A, Indahl O, Keller A, et al. Randomized clinical trial of lumbar instrumented fusion and cognitive intervention and exercises in patient with chronic low back pain and disc degeneration. Spine 2003;28:1913-21.

\section{Buhrman 2004 \{published data only\}}

Buhrman M, Faltenhag S, Strom L, Andersson G. Controlled trial of Internet-based treatment with telephone support for chronic back pain. Pain 2004;111:368-77.

\section{Carson 2005 \{published data only\}}

Carson JW, Keefe FJ, Lynch TR, Carson KM, Goli V, Fras AM, et al. Loving-kindness meditation for chronic low back pain: results from a pilot trial. Journal of Holistic Nursing 2005;23:287-304.

\section{Carson 2010 \{published data only\}}

Carson JW, Carson KM, Jones KD, Bennett RM, Wright CL, Mist SD. A pilot randomized controlled trial of the Yoga of Awareness program in the management of fibromyalgia. Pain 2010;151:530-9.

\section{Castel 2009 \{published data only\}}

Castel A, Salvat M, Sala J, Rull M. Cognitive-behavioural group treatment with hypnosis: a randomized pilot trial in fibromyalgia. Contemporary Hypnosis 2009;26:48-59.

\section{Christiansen 2010 \{published data only\}}

Christiansen S, Oettingen G, Dahme B, Klinger R. A short goalpursuit intervention to improve physical capacity: a randomized clinical trial in chronic back pain patients. Pain 2010;149:444-52.

\section{Cook 1998 \{published data only\}}

Cook AJ. Cognitive-behavioral pain management for elderly nursing home residents. Journals of Gerontology. Series B, Psychological Sciences and Social Sciences 1998;53B:51-9.

\section{Corrado 2003 \{published data only\}}

Corrado PE, Gottlieb H, Abdelhamid MH. The effect of biofeedback and relaxation training on anxiety and somatic complaints in chronic pain patients. American Journal of Pain Management 2003;13:133-9.

\section{Currie 2000 \{published data only\}}

Currie SR, Wilson KG, Pontefract AJ, deLaplante L. Cognitivebehavioral treatment of insomnia secondary to chronic pain Journal of Consulting \& Clinical Psychology 2000;68:407-16.

\section{Dahl 2004 \{published data only\}}

Dahl J, Wilson KG, Nilsson A. Acceptance and commitment therapy and the treatment of persons at risk for longterm disability resulting from stress and pain symptoms: a preliminary randomized trial. Behavior Therapy 2004;35:785-801.

\section{Dalton 2004 \{published data only\}}

Dalton JA, Keefe FJ, Carlson J, Youngblood R. Tailoring cognitive-behavioral treatment for cancer pain. Pain Management Nursing 2004;5:3-18. de Sousa 2009 \{published data only\}

de Sousa KS da FL, Orfale AG, Meireles SM, Leite JR, Natour J. Assessment of a biofeedback program to treat chronic low back pain. Journal of Musculoskeletal Pain 2009;17(4):369-77.

\section{Dufour 2010 \{published data only\}}

Dufour N, Thamsborg G, Oefeldt A, Lundsgaard C, Stender S. Treatment of low back pain. A randomized clinical trial comparing group-based multidisciplinary biopsychosocial rehabilitation and intensive individual therapist-assisted back muscle strengthening exercises. Spine 2010;35(5):469-76.

Dworkin 1994 \{published data only\}

Dworkin SF, Turner JA, Wilson L, Massoth D, Whitney C, Huggins $\mathrm{KH}$, et al. Brief group cognitive-behavioral intervention for temporomandibular disorders. Pain 1994;59:175-87.

Dworkin 2002a \{published data only\}

Dworkin SF, Turner JA, Mancl L, Wilson L, Massoth D, Huggins $\mathrm{KH}$, et al. A randomized clinical trial of a tailored comprehensive care treatment program for temporomandibular disorders. Journal of Orofacial Pain 2002;16:259-76.

\section{Dworkin 2002b \{published data only\}}

Dworkin SF, Huggins KH, Wilson L, Mancl L, Turner J, Massoth D, et al. A randomized clinical trial using research diagnostic criteria for temporomandibular disorders-axis II to target clinic cases for a tailored self-care TMD treatment program. Journal of Orofacial Pain 2002;16:48-63.

\section{Edinger 2005 \{published data only\}}

Edinger JD, Wohlgemuth WK, Krystal AD, Rice JR. Behavioral insomnia therapy for fibromyalgia patients: a randomized clinical trial. Archives of Internal Medicine 2005;165:2527-35.

\section{Ersek 2003 \{published data only\}}

Ersek M, Turner JA, McCurry SM, Gibbons L, Kraybill BM. Efficacy of a self-management group intervention for elderly persons with chronic pain. Clinical Journal of Pain 2003;19:156-67.

\section{Esmer 2010 \{published data only\}}

Esmer G, Blum J, Rulf J, Pier J. Mindfulness-based stress reduction for failed back surgery syndrome: a randomized controlled trial. Journal of the American Osteopathic Association 2010;110:646-52.

\section{Evans 2003 \{published data only\}}

Evans S, Fishman B, Spielman L, Haley A. Randomized trial of cognitive behavior therapy versus supportive psychotherapy for HIV-related peripheral neuropathic pain. Psychosomatics 2003;44:44-50.

\section{Fairbank 2005 \{published data only\}}

Fairbank J, Frost H, Wilson-MacDonald J, Yu LM, Barker K, Collins R. Randomised controlled trial to compare surgical stabilisation of the lumbar spine with an intensive rehabilitation programme for patients with chronic low back pain: the MRC spine stabilisation trial. BMJ 2005;330:1-7. 
Rivero-Arias O, Campbell H, Gray A, Fairbank J, Frost H, WilsonMacDonald J. Surgical stabilisation of the spine compared with a programme of intensive rehabilitation for the management of patients with chronic low back pain: cost utility analysis based on a randomised controlled trial. BMJ 2005;330:1239-43.

\section{Ferrari 2006 \{published data only\}}

Ferrari R, Fipaldini E, Birbaumer N. Individual characteristics and results of biofeedback training and operant treatment in patients with chronic pain [Caratteristiche individuali e risultati del biofeedback training e del trattamento operante in pazienti con dolore cronico]. Psicoterapia Cognitiva e Comportmentale 2006;12:161-79.

\section{Flor 1993 \{published data only\}}

Flor $\mathrm{H}$, Birbaumer N. Comparison of the efficacy of electromyographic biofeedback, cognitive-behavioral therapy, and conservative medical interventions in the treatment of chronic musculoskeletal pain. Journal of Consulting and Clinical Psychology 1993;61:653-8.

\section{Fors 2000 \{published data only\}}

Fors EA, Gotestam KG. Patient education, guided imagery and pain related talk in fibromyalgia coping. European Journal of Psychiatry 2000;14:233-40.

\section{Freeman 2002 \{published data only\}}

Freeman K, Hammond A, Lincoln N. Use of cognitivebehavioural arthritis education programmes in newly diagnosed rheumatoid arthritis. Clinical Rehabilitation 2002;16:828-36.

\section{Garcia-Campayo 2009 \{published data only\}}

Garcia-Campayo J, Serrano-Blanco A, Rodero B, Magallon R, Alda $M$, Andres $E$, et al. Effectiveness of the psychological and pharmacological treatment of catastrophization in patients with fibromyalgia: a randomized controlled trial. Trials 2009;10:24.

\section{George 2008 \{published data only\}}

George SZ, Zeppieri G, Cere AL, Cere MR, Borut MS, Hodges MJ, et al. A randomized trial of behavioral physical therapy interventions for acute and sub-acute low back pain (NCT00373867). Pain 2008;140:145-57.

\section{Glombiewski 2010a \{published data only\}}

Glombiewski JA, Hartwich-Tersek J, Rief W. Depression in chronic back pain patients: prediction of pain intensity and pain disability in cognitive-behavioral treatment. Psychosomatics 2010;51(2):130-6.

\section{Haugstad 2006 \{published data only\}}

Haugstad GK, Haugstad TS, Kirste UM, Leganger S, Klemmetsen I, Malt UF. Mensendieck somatocognitive therapy as treatment approach to chronic pelvic pain: results of a randomized controlled intervention study. American Journal of Obstetrics and Gynecology 2006;194:1303-10.

\section{Jensen 2009 \{published data only\}}

Jensen MP, Barber J, Romano JM, Hanley MA, Raichle KA, Molton IR, et al. Effects of self-hypnosis training and EMG biofeedback relaxation training on chronic pain in persons with spinal-cord injury. International Journal of Clinical and Experimental Hypnosis 2009;57:239-68.

\section{Johansson 1998 \{published data only\}}

Johansson C, Dahl J, Jannert M, Melin L, Andersson G. Effects of a cognitive-behavioral pain-management program. Behaviour Research and Therapy 1998;36:915-30.

Kapitza 2010 \{published data only\}

Kapitza KP, Passie T, Bernateck M, Karst M. First non-contingent respiratory biofeedback placebo versus contingent biofeedback in patients with chronic low back pain: a randomized, controlled, double-blind trial. Applied Psychophysiology and Biofeedback 2010;35:207-17.

Keefe 2004 \{published data only\}

Keefe FJ, Blumenthal J, Baucom D, Affleck G, Waugh R, Caldwell DS, et al. Effects of spouse-assisted coping skills training and exercise training in patients with osteoarthritic knee pain: a randomized controlled study. Pain 2004;110:539-49.

\section{Keller 2004 \{published data only\}}

Keller A, Brox JI, Gunderson R, Holm I, Friis A, Reikeras O. Trunk muscle strength, cross-sectional area, and density in patients with chronic low back pain randomized to lumbar fusion or cognitive intervention and exercises. Spine 2004;29:3-8.

\section{Kerns 1986 \{published data only\}}

Kerns RD, Turk DC, Holzman AD, Rudy TE. Comparison of cognitive-behavioral and behavioral approaches to the outpatient treatment of chronic pain. Clinical Journal of Pain 1986;1:195-203.

\section{Kroenke 2009 \{published data only\}}

Kroenke K, Bair MJ, Damush TM, Wu J, Hoke S, Sutherland J, et al. Optimized antidepressant therapy and pain selfmanagement in primary care patients with depression and musculoskeletal pain. JAMA 2009;301:2099-110.

\section{Lamb 2010 \{published data only\}}

Lamb SE, Hansen Z, Castelnuovo E, Withers EJ, Nichols V, Potter R, et al. on behalf of the Back Skills Training Trial Investigators. Group cognitive behavioural treatment for lowback pain in primary care: a randomised controlled trial and cost-effectiveness analysis. Lancet 2010;375:916-23.

\section{Lambeek 2009 \{published data only\}}

Lambeek LC, van Mechelen W, Buijs PC, Loisel P, Anema JR. An integrated care program to prevent work disability due to chronic low back pain: a process evaluation within a randomized controlled trial. BMC Musculoskeletal Disorders 2009;10:147-56.

\section{Li 2006 \{published data only\}}

Li EJQ, Li-Tsang CWP, Lam CS, Hui KYL, Chan CCH. The effect of a "training on work readiness" program for workers with musculoskeletal injuries: a randomized control trial (RCT) study. Journal of Occupational Rehabilitation 2006;16:529-41. 
Liedl 2011 \{published data only\}

Liedl A, Müller J, Morina N, Karl A, Denke C, Knaevelsrud C. Physical activity within a CBT intervention improves coping with pain in traumatized refugees: results of a randomized controlled design. Pain Medicine 2011;12:234-45.

\section{Linton 1984 \{published data only\}}

Linton SJ, Gotestam KG. A controlled study of the effects of applied relaxation plus operant procedures in the regulation of chronic pain. British Journal of Clinical Psychology 1984;23:291-9.

\section{Linton 1985 \{published data only\}}

Linton SJ, Melin L, Stjernlof K. The effects of applied relaxation and operant activity on chronic pain. Behavioural Psychotherapy 1985;13:87-100.

\section{Linton 2001 \{published data only\}}

Linton SJ, Ryberg M. A cognitive-behavioral group intervention as prevention for persistent neck and back pain in a non-patient population: a randomized controlled trial. Pain 2001;90:83-90.

\section{Linton 2005 \{published data only\}}

Linton SJ, Boersma K, Jansson M, Svard L, Botvalde M. The effects of cognitive behavioural and physical therapy preventive interventions on pain related sick leave. Clinical Journal of Pain 2005;21:109-19.

\section{Linton 2008 \{published data only\}}

Linton SJ, Boersma K, Jansson M, Overmeer T, Lindblom K, Vlaeyen JWS. A randomized controlled trial of exposure in vivo for patients with spinal pain reporting fear of work-related activities. European Journal of Pain 2008;12:722-30.

\section{Lorig 2008 \{published data only\}}

Lorig KR, Ritter PL, Laurent DD, Plant K. The internet-based arthritis self-management program: a one-year randomized trial for patients with arthritis or fibromyalgia. Arthritis Care and Research 2008;59:1009-17.

\section{Machado 2007 \{published data only\}}

Machado LAC, Azevedo DC, Capanema MB, Neto TN, Cerceau DM. Client-centered therapy vs exercise therapy for chronic low back pain: a pilot randomized controlled trial in Brazil. Pain Medicine 2007;8:251-8.

\section{Marhold 2001 \{published data only\}}

Marhold C, Linton SJ, Melin L. A cognitive-behavioral return-towork program: effects on pain patients with a history of longterm versus short-term sick leave. Pain 2001;91:155-63.

\section{Menzel 2006 \{published data only\}}

Menzel NN, Robinson ME. Back pain in direct patient care providers: early intervention with cognitive behavioral therapy. Pain Management Nursing 2006;7:55-63.

\section{Moffett 2005 \{published data only\}}

Moffett JAK, Jackson DA, Richmond S, Hahn S, Coulton S, Farrin A. Randomised trial of a brief physiotherapy intervention compared with usual physiotherapy for neck pain patients: outcomes and patients' preference. BMJ 2005;330:75-8.

\section{Moore 1985 \{published data only\}}

Moore JE, Chaney EF. Outpatient group treatment of chronic pain: effects of spouse involvement. Journal of Consulting and Clinical Psychology 1985;53:326-34.

\section{Moore 2000 \{published data only\}}

Moore JE, Von Korff M, Cherkin D, Saunders K, Lorig K. A randomized trial of a cognitive-behavioral program for enhancing back pain self care in a primary care setting. Pain 2000;88:145-53.

\section{Morone 2008 \{published data only\}}

Morone NE, Greco CM, Weiner DK. Mindfulness meditation for the treatment of chronic low back pain in older adults: a randomized controlled pilot study. Pain 2008;134:310-9.

Morone 2009 \{published data only\}

Morone NE, Rollman BL, Moore CG, Qin L, Weiner DK. A mindbody program for older adults with chronic low back pain: results of a pilot study. Pain Medicine 2009;10:1395-407.

\section{Newton-John 1995 \{published data only\}}

Newton-John TO, Spence SH, Schotte D. Cognitive-behavioral therapy versus EMG biofeedback in the treatment of chronic low back pain. Behaviour Research and Therapy 1995;33:691-7.

\section{Nicholas 1991 \{published data only\}}

Nicholas MK, Wilson PH, Goyen J. Operant-behavioural and cognitive-behavioural treatment for chronic low back pain. Behaviour Research and Therapy 1991;29:225-38.

Nicholas 1992 \{published data only\} Nicholas MK, Wilson PH, Goyen J. Comparison of cognitivebehavioral group treatment and an alternative nonpsychological treatment for chronic low back pain. Pain 1992;48:339-47.

\section{O'Leary 1988 \{published data only\}}

O'Leary A, Shoor S, Lorig K, Holman HR. A cognitive-behavioral treatment for rheumatoid arthritis. Health Psychology 1988; 7:527-44.

\section{Parker 2003 \{published data only\}}

Parker JC, Smarr KL, Slaughter JR, Johnston SK, Priesmeyer ML, Hanson KD, et al. Management of depression in rheumatoid arthritis: a combined pharmacologic and cognitive-behavioral approach. Arthritis and Rheumatism 2003;49:766-77.

\section{Peters 1990 \{published data only\}}

Peters J, Large RG, Elkind G. Follow-up results from a randomised controlled trial evaluating in- and outpatient pain management programmes. Pain 1992;50:41-50.

Peters JL, Large RG. A randomised control trial evaluating in- and outpatient pain management programmes. Pain 1990;41:283-93.

\section{Radojevic 1992 \{published data only\}}

Radojevic V, Nicassio PM, Weisman MH. Behavioral intervention with and without family support for rheumatoid arthritis. Behavior Therapy 1992;23:13-30. 
Redondo 2004 \{published data only\}

Redondo JR, Justo CM, Moraleda FV, Velayos YG, Puche JJ, Zubero JR, et al. Long-term efficacy of therapy in patients with fibromyalgia: a physical exercise-based program and a cognitive-behavioral approach. Arthritis and Rheumatism 2004;51:184-92.

\section{Rendant 2011 \{published data only\}}

Rendant D, Pach D, Ludtke R, Reisshauser A, Mietzner A, Willich SN, et al. Qigong versus exercise versus no therapy for patients with chronic neck pain. Spine 2011;36(6):419-27.

Sahin 2011 \{published data only\}

Sahin N, Albayrak I, Durmus B, Ugurlu H. Effectiveness of back school for treatment of pain and functional disability in patients with chronic low back pain: a randomized controlled trial. Journal of Rehabilitation Medicine 2011;43:224-9.

\section{Schulze 2008 \{published data only\}}

Schulze H, Bischoff C, v Pein A, Limbacher K. Conception and evaluation of a group therapy intervention for patients with chronic pain disorders and applications for early retirement pensions [Konzeption und Evaluation einer socialmedizinischen Patientenschulung fur chronische Shmerzpatienten mit laufendem Rentenverfahren]. Rehabilitation 2008;47:211-8.

\section{Schweikert 2006 \{published data only\}}

Schweikert B, Jacobi E, Seitz R, Cziske R, Ehlert A, Knab J, et al. Effectiveness and cost-effectiveness of adding a cognitivebehavioral treatment to the rehabilitation of chronic low back pain. Journal of Rheumatology 2006;33:2519-26.

\section{Sharpe 2001 \{published data only\}}

Sharpe L, Sensky T, Timberlake N, Ryan B, Brewin C, Allard S. A blind, randomized, controlled trial of cognitive-behavioural intervention for patients with recent onset rheumatoid arthritis: preventing psychological and physical morbidity. Pain 2001;89:275-83.

\section{Smeets 2009 \{published data only\}}

Smeets RJ, Severens JL, Beelen S, Vlaeyen JWS, Knottnerus A. More is not always better: cost-effectiveness analysis of combined, single behavioral and single physical rehabilitation programs for chronic low back pain. European Journal of Pain 2009;13:71-81.

\section{Soderlund 2001 \{published data only\}}

Soderlund A, Lindberg P. Cognitive behavioural components in physiotherapy management of chronic whiplash associated disorders (WAD) -- a randomized group study. Physiotherapy Theory \& Practice 2001;17:229-38.

\section{Spence 1989 \{published data only\}}

* Spence SH. Cognitive-behavior therapy in the management of chronic, occupational pain of the upper limbs. Behaviour Research and Therapy 1989;27:435-46.

Spence SH. Cognitive-behaviour therapy in the treatment of chronic, occupational pain of the upper limbs: a $2 \mathrm{yr}$ follow-up. Behaviour Research and Therapy 1991;29:503-9.

\section{Spence 1995 \{published data only\}}

Spence SH, Sharpe L, Newton-John T, Champion D. Effect of EMG biofeedback compared to applied relaxation training with chronic, upper extremity cumulative trauma disorders. Pain 1995;63:199-206.

\section{Strong 1998 \{published data only\}}

Strong J. Incorporating cognitive-behavioral therapy with occupational therapy: a comparative study with patients with low back pain. Journal of Occupational Rehabilitation 1998;8:61-71.

\section{Turner 1982 \{published data only\}}

Turner JA. Comparison of group progressive-relaxation training and cognitive-behavioral group therapy for chronic low back pain. Journal of Consulting and Clinical Psychology 1982;50:757-65.

\section{Turner 1990 \{published data only\}}

Turner JA, Clancy S, McQuade KJ, Cardenas DD. Effectiveness of behavioral therapy for chronic low back pain: a component analysis. Journal of Consulting and Clinical Psychology 1990;58:573-9.

\section{Turner 1993 \{published data only\}}

Turner JA, Jensen MP. Efficacy of cognitive therapy for chronic low back pain. Pain 1993;52:169-77.

\section{Turner 2011 \{published data only\}}

Turner JA, Mancl L, Huggins JH, Sherman JJ, Lentz G, LeResche L. Targeting temporomandibular disorder pain treatment to hormonal fluctuations: a randomized clinical trial. Pain 2011;152:2074-84.

\section{Turner-Stokes 2003 \{published data only\}}

Turner-Stokes L, Erkeller-Yuksel F, Miles A, Pincus T, Shipley M, Pearce $S$. Outpatient cognitive behavioral pain management programs: a randomized comparison of a group-based multidisciplinary versus an individual therapy model. Archives of Physical Medicine and Rehabilitation 2003;84:781-8.

\section{Van den Hout 2003 \{published data only\}}

van den Hout JH, Vlaeyen JW, Heuts PH, Zijlema JH, Wijnen JA. Secondary prevention of work-related disability in nonspecific low back pain: does problem-solving therapy help? A randomized clinical trial. Clinical Journal of Pain 2003;19:87-96.

\section{Van Lankveld 2004 \{published data only\}}

van Lankveld W, van Helmond T, Naring G, de Rooij DJ, van den Hoogen F. Partner participation in cognitive-behavioral selfmanagement group treatment for patients with rheumatoid arthritis. Journal of Rheumatology 2004;31:1738-45.

\section{Vlaeyen 1995 \{published data only\}}

Vlaeyen JW, Haazen IW, Schuerman JA, Kole-Snijders AM, van Eek $\mathrm{H}$. Behavioural rehabilitation of chronic low back pain: comparison of an operant treatment, an operant-cognitive treatment and an operant-respondent treatment. British Journal of Clinical Psychology 1995;34:95-118. 
Wicksell 2008 \{published data only\}

Wicksell RA, Ahlqvist J, Bring A, Melin L, Olsson GL. Can exposure and acceptance strategies improve functioning and life satisfaction in people with chronic pain and whiplashassociated disorders (WAD)? A randomized controlled trial. Cognitive Behaviour Therapy 2008;37:169-82.

Wong 2011 \{published data only\}

Wong SY-S, Chan FW-K, Wong RL-P, Chu M-C, Lam Y-YK, Mercer SW, et al. Comparing the effectiveness of mindfulnessbased stress reduction and multidisciplinary intervention programs for chronic pain. A randomized comparative trial. Clinical Journal of Pain 2011;27:724-34.

Woods 2008 \{published data only\}

Woods MP, Asmundson GJG. Evaluating the efficacy of graded in vivo exposure for the treatment of fear in patients with chronic low back pain: a randomized controlled clinical trial. Pain 2008;136:271-80.

\section{References to studies awaiting assessment}

Bergdahl 1995 \{published data only\}

Bergdahl J, Anneroth G, Perris H. Cognitive therapy in the treatment of patients with resistant burning mouth syndrome: a controlled study. Journal of Oral Pathology and Medicine 1995;24:213-5.

\section{Additional references}

\section{Alschuler 2008}

Alschuler KN, Theisen-Goodvich ME, Haig AJ, Geisser ME. A comparison of the relationship between depression, perceived disability, and physical performance in persons with chronic pain. European Journal of Pain 2008;12:757-64.

\section{Barkham 2006}

Barkham M, Connell J, Stiles WB, Miles JNV, Margison F, Evans $C$, et al. Dose-effect relations and responsive regulation of treatment duration: the good enough level. Journal of Consulting and Clinical Psychology 2006;74(1):160-7.

\section{Beale 2011}

Beale M, Cella M, Williams AC. Comparing patients' and clinician-researchers' outcome choice for psychological treatment of chronic pain. Pain 2011;152:2283-6.

\section{Bender 2011}

Bender JL, Radhakrishnan K, Diorio C, Englesakis M. Can pain be managed through the internet? A systematic review of randomized controlled trials. Pain 2011;152:1740-7.

\section{Bernady 2010}

Bernady K, Füber N, Köllner V, Häuser W. Efficacy of cognitivebehavioral therapies in fibromyalgia syndrome - a systematic review and metaanalysis of randomized controlled trials. Journal of Rheumatology 2010;37:1991-2005.

\section{Blyth 2007}

Blyth FM, Macfarlane GJ, Nicholas MK. Topical review: the contribution of psychosocial factors to the development of chronic pain: the key to better outcomes for patients?. Pain 2007;129:8-11.

\section{Boutron 2008}

Boutron I, Moher D, Altman D, Schulz KF, Ravaud P. Extending the CONSORT Statement to randomized trials of nonpharmacologic treatment: explanation and elaboration. Annals of Internal Medicine 2008;148:295-309.

\section{Bowling 1997}

Bowling A. Measuring Health. 2nd Edition. Buckingham: Open University Press, 1997.

\section{Breivik 2006}

Breivik H, Collett B, Ventafridda V, Cohen B, Gallacher D. Survey of chronic pain in Europe: prevalence, impact on daily life, and treatment. European Journal of Pain 2006;10:287-333.

\section{Brown Brunnhuber 2006}

Brown P, Brunnhuber K, Chalkidou K, Chalmers I, Fenton M, Forbes $\mathrm{C}$, et al. How to formulate research recommendations. BMJ 2006;333:804-6.

\section{Butler 2006}

Butler AC, Chapman JE, Forman EM, Beck AT. The empirical status of cognitive-behavioral therapy: a review of metaanalyses. Clinical Psychology Review 2006;26:17-31.

\section{Craig 2008}

Craig P, Dieppe P, Macintyre S, Michie S, Nazareth I, Petticrew M, on behalf of the Medical Research Council. Developing and evaluating complex interventions: new guidance. www.mrc.ac.uk/complexinterventionsguidance 2008.

\section{Curran 2009}

Curran C, Williams AC, Potts HWW. Cognitive-behavioral therapy for persistent pain: does adherence after treatment affect outcome?. European Journal of Pain 2009;13:178-88.

\section{Dixon 2007}

Dixon KE, Keefe FJ, Scipio CD, Perri LM, Abernathy AP. Psychological interventions for arthritis pain management in adults: a meta-analysis. Health Psychology 2007;26:241-50.

\section{Dworkin 2005}

Dworkin RH, Turk DC, Farrar JT, Haythornthwaite JA, Jensen MP, Katz NP, et al. Topical review and recommendations: core outcome measures for chronic pain clinical trials: IMMPACT recommendations. Pain 2005;113:9-19.

\section{Dworkin 2008}

Dworkin RH, Turk DC, Wyrwich KW, Beaton D, Cleeland CS, Farrar JT, et al. Interpreting the clinical importance of treatment outcomes in chronic pain clinical trials: IMMPACT recommendations. Journal of Pain 2008;9:105-21. 


\section{Eccleston 2007}

Eccleston C, Crombez G. Worry and chronic pain: a misdirected problem solving model. Pain 2007;132:233-6.

\section{Eccleston 2009b}

Eccleston C, Palermo TM, Williams AC, Lewandowski A, Morley S. Psychological therapies for the management of chronic and recurrent pain in children and adolescents. Cochrane Database of Systematic Reviews 2009, Issue 2. [DOI: 10.1002/14651858.CD003968.pub2]

\section{Flor 1992}

Flor H, Fydrich T, Turk DC. Efficacy of multidisciplinary pain treatment centers: a meta-analytic review. Pain 1992;49:221-30.

\section{Fordyce 1968}

Fordyce WE, Fowler RS Jr, Lehmann JF, DeLateur BJ. Some implications of learning on problems of chronic pain. Journal of Chronic Disease 1968;21(3):179-90.

\section{Furlan 2001}

Furlan AD, Clarke J, Esmail R, Sinclair S, Irvin E, Bombardier C. A critical review of reviews on the treatment of low back pain. Spine 2001;26:E155-62.

\section{Garratt 2008}

Garratt A. Patient reported outcomes in trial. BMJ 2008;337:a1190.

\section{Gatchel 2006}

Gatchel RJ, Okifuji A. Evidence-based scientific data documenting the treatment and cost-effectiveness of comprehensive pain programs for chronic non-malignant pain. Journal of Pain 2006;7:779-93.

\section{Glombiewski 2010}

Glombiewski JA, Hartwich-Tersek J, Rief W. Depression in chronic back pain patients: prediction of pain intensity and pain disability in cognitive-behavioral treatment. Psychosomatics 2010;51:130-6.

\section{Grimshaw 1995}

Grimshaw J, Freemantle N, Langhorne P, Song F. Complexity and systematic reviews: Report to the US Congress, Office of Technology Assessment. Aberdeen: University of Aberdeen, Scotland 1995.

\section{Guzman 2001}

Guzmán J, Esmail R, Karjalainen K, Malmivaara A, Irvin E, Bombardier C. Multidisciplinary rehabilitation for chronic low back pain: systematic review. BMJ 2001;322:1511-6.

\section{Hellum 2011}

Hellum C, Johnsen LG, Storheim K, Nygaard Ø, Brox JI, Rosvoll I, et al. Norwegian Spine Study Group. Surgery with disc prosthesis versus rehabilitation in patients with low back pain and degenerative disc: two year follow-up of randomised study. BMJ 2011;342:d2786.

\section{Henschke 2010a}

Henschke N, Ostelo RWJG, van Tulder MW, Vlaeyen JWS, Morley S, Assendelft WJJ, et al. Behavioural treatments for chronic low back pain. Cochrane Database of Systematic Reviews 2010, Issue 7. [DOI: 10.1002/14651858.CD002014.pub3]

\section{Higgins 2011}

Higgins JPT, Green S (editors). Cochrane Handbook for Systematic Reviews of Interventions Version 5.1.0 [updated March 2011]. The Cochrane Collaboration, 2011. Available from www.cochrane-handbook.org.

\section{Hoffman 2007}

Hoffman BM, Papas RK, Chatkoff DK, Kerns RD. Meta-analysis of psychological interventions for chronic low back pain. Health Psychology 2007;26:1-9.

\section{Hrobarjtsson 2001}

Hrobarjtsson A, Gotzsche PC. Is the placebo powerless? - An analysis of clinical trials comparing placebo with no treatment. New England Journal of Medicine 2001;344:1594-602.

\section{Hrobarjtsson 2004}

Hrobarjtsson A, Gotzsche PC. Is the placebo powerless? Update of a systematic review with 52 new randomized trials comparing placebo with no treatment. Journal of Internal Medicine 2004;256:91-100.

\section{Häuser 2009}

Häuser W, Bernardy K, Arnold B, Offenbächer M, Schiltenwolf M. Efficacy of multicomponent treatment in fibromyalgia syndrome: a meta-analysis of randomized controlled trials . Arthritis and Rheumatism 2009;61:216-24.

\section{loannidis 2005}

Ioannidis JPA. Why most published research findings are false. PloS Medicine 2005;2:e124.

\section{Jensen 2011}

Jensen MP. Psychosocial approaches to pain management: an organizational framework. Pain 2011;152:717-25.

\section{Keefe Rumble 2004}

Keefe FJ, Rumble ME, Scipio CD, Giordano LA, Perri LM. Psychological aspects of persistent pain: current state of the science. Journal of Pain 2004;5:195-211.

\section{Knittle 2010}

Knittle K, Maes S, De Gucht V. Psychological interventions for rheumatoid arthritis: examining the role of self-regulation with a systematic review and meta-analysis of randomized controlled trials. Arthritis and Rheumatism 2010;62:1460-72.

\section{Lambert 2001}

Lambert MJ, Hansen NB, Finch AE. Patient-focused research: using patient outcome data to enhance treatment effects. Journal of Consulting and Clinical Psychology 2001;69:159-72.

\section{Leeuw Goossens 2008}

Leeuw M, Goossens MEJB, de Vet HCW, Vlaeyen JWS. The fidelity of treatment delivery can be assessed in treatment 
outcome studies: a successful illustration from behavioral medicine. Journal of Clinical Epidemiology 2008;62:81-90.

\section{Lin 2011}

Lin C-WC, McAuley JH, Macedo L, Barnett DC, Smeets RJ, Verbunt JA. Relationship between physical activity and disability in low back pain: a systematic review and metaanalysis. Pain 2011;152:607-13.

\section{Macea 2010}

Macea DD, Gajos K, Calil YAD, Fregni F. The efficacy of webbased cognitive-behavioral interventions for chronic pain: a systematic review and meta-analysis. Journal of Pain 2010;11(10):917-29.

\section{McMillan 2010}

McMillan D, Morley S. Single case quantitative methods for practice-based evidence. In: Barkham M, Hardy GE, Mellor-Clark J editor(s). Developing and Delivering Practice-based Evidence: A Guide for the Psychological Therapies. Chichester: John Wiley \& Sons, 2010:109-38.

\section{Moore 2005}

Moore RA, Edwards JE, McQuay HJ. Acute pain: individual patient meta-analysis shows the impact of different ways of analysing and presenting results. Pain 2005;116:322-31.

\section{Moore 2010}

Moore RA, Derry S, McQuay HJ, Straube S, Aldington D, Wiffen P, et al. Clinical effectiveness: an approach to clinical trial design more relevant to clinical practice, acknowledging the importance of individual differences. Pain 2010;149:173-6.

\section{Morley 1999}

Morley S, Eccleston C, Williams A. Systematic review and metaanalysis of randomized controlled trials of cognitive behaviour therapy and behaviour therapy for chronic pain in adults, excluding headache. Pain 1999;80:1-13.

\section{Morley 2006}

Morley SJ, Williams AC de C. RCTs of psychological treatments for chronic pain: progress and challenges. Pain 2006;121:171-2.

\section{Morley 2008}

Morley S, Williams A, Hussain S. Estimating the clinical effectiveness of cognitive behavioural therapy in the clinic: evaluation of a CBT informed pain management programme. Pain 2008;137:670-80.

\section{Morley 2011}

Morley SJ. Efficacy and effectiveness of cognitive behaviour therapy for chronic pain: progress and some challenges. Pain 2011;152:S99-S106.

\section{Moss-Morris 2007}

Moss-Morris R, Humphrey K, Johnson MH, Petrie KJ. Patients' perception of their pain condition across a multidisciplinary pain management programme. Do they change and if so does it matter?. Clinical Journal of Pain 2007;23:558-64.

\section{Nestoriuc 2007}

Nestoriuc Y, Martin A. Efficacy of biofeedback for migraine: a meta analysis. Pain 2007;118:111-27.

\section{Nestoriuc 2008}

Nestoriuc Y, Rief W, Martin A. Meta analysis of biofeedback for tension type headache: efficacy, specificity, and treatment moderators. Journal of Consulting and Clinical Psychology 2008;76:379-96.

\section{Nicholas 2010}

Nicholas MK. Obstacles to recovery after an episode of low back pain: the 'usual suspects' are not always guilty. Pain 2010;149:363-4.

\section{Nuesch 2009}

Nuesch E, Trelle S, Reichenbach S, Rutjes AW, Burgi E, Scherer M, et al. The effects of excluding patients from the analysis in randomised controlled trials: meta-epidemiological study. BMJ 2009;339:b3244.

\section{Roth 2005}

Roth AD, Fonagy P. What Works for Whom: A Critical Review of Psychotherapy Research. 2nd Edition. New York: Guildford Press, 2005.

\section{Scascighini 2008}

Scascighini L, Toma V, Dober-Spielmann S, Sprott H. Multidisciplinary treatment for chronic pain: a systematic review of interventions and outcomes. Rheumatology 2008;47:670-8.

\section{Shepperd 2009}

Shepperd S, Lewin S, Straus S, Clarke M, Eccles MP, Fitzpatrick R, et al. Can we systematically review studies that evaluate complex interventions?. PLoS Medicine 2009;6:e1000086.

\section{Shojania 2007}

Shojania KG, Sampson M, Ansari MT, Jun J, Doucette S, Moher D. How quickly do systematic reviews go out of date? A survival analysis. Annals of Internal Medicine 2007;147:224-33.

\section{Somerville 2008}

Somerville S, Hay E, Lewis M, Barber J, van der Windt D, Hill J, et al. Content and outcome of usual primary care for back pain: a systematic review . British Journal of Clinical Practice 2008;58:790-7.

\section{Thorn 2007}

Thorn BE, Cross TH, Walker BB. Meta-analyses and systematic reviews of psychological treatments for chronic pain: relevance to an evidence-based practice. Health Psychology 2007;26:10-2.

\section{Thorn Burns 2011}

Thorn BE, Burns JW. Commentary: common and specific treatment mechanisms in psychosocial pain interventions: the need for a new research agenda. Pain 2011;152:705-6. 


\section{Turk 2008}

Turk DC, Dworkin RH, Revicki D, Harding G, Burke LB, Cella D, et al. Identifying important outcome domains for chronic pain clinical trials: an IMMPACT survey of people with pain. Pain 2008;137:276-85.

\section{Turk Okifuji 2002}

Turk DC, Okifuji A. Psychological factors in chronic pain: evolution and revolution. Journal of Consulting and Clinical Psychology 2002;70:678-90.

\section{Underwood 2011}

Underwood M, Mistry G, Lall R, Lamb S. Predicting response to a cognitive-behavioral approach to treating low back pain: secondary analysis of the BeST data set. Arthritis Care and Research 2011;63:1271-9.

\section{Veehof 2011}

Veehof MM, Oskam M-J, Schreurs KMG, Bohlmeijer ET. Acceptance-based interventions for the treatment of chronic pain: a systematic review and meta-analysis. Pain 2011;152:533-42.

\section{Verbunt 2010}

Verbunt JA, Smeets RJ, Wittink HM. Cause or effect? Deconditioning and chronic low back pain. Pain 2010;149:428-30.

\section{Vlaeyen de Jong 2001}

Vlaeyen JWS, de Jong J, Geilen M, Heuts PHTG, van Breukelen G. Graded exposure in vivo in the treatment of

\section{CHARACTERISTICS OF STUDIES}

Characteristics of included studies [ordered by study ID] pain-related fear: a replicated single-case experimental design in four patients with chronic low back pain. Behaviour Research and Therapy 2001;39:151-66.

\section{Waller 2009}

Waller G. Evidence-based treatment and therapist drift. Behaviour Research and Therapy 2009;47:119-27.

\section{Wideman 2009}

Wideman TH, Adams H, Sullivan MJL. A prospective sequential analysis of the fear-avoidance model of pain. Pain 2009;145:45-51.

\section{Wren 2011}

Wren AA, Wright MA, Carson JW, Keefe FJ. Yoga for persistent pain: new findings and directions for an ancient practice. Pain 2011;152:477-80.

\section{Yates 2005}

Yates SL, Morley S, Eccleston E, Williams A. A scale for rating the quality of psychological trials for pain. Pain 2005;117:314-25.

\section{References to other published versions of this review Eccleston 2009a}

Eccleston C, Williams ACdeC, Morley S. Psychological therapies for the management of chronic pain (excluding headache) in adults. Cochrane Database of Systematic Reviews 2009, Issue 2. [DOI: 10.1002/14651858.CD007407.pub2]

* Indicates the major publication for the study

Alaranta 1994

\begin{tabular}{|c|c|}
\hline Methods & RCT; 2 arms;assessed at pretreatment, 3 months follow-up, 1 year follow-up \\
\hline \multirow[t]{7}{*}{ Participants } & 3 month follow-up $n=286$ \\
\hline & Start of treatment $n=293$ \\
\hline & Sex: $160 F, 133$ M \\
\hline & Mean age $=40.5($ SD 4.5$)$ \\
\hline & Source $=$ patients referred for inpatient rehabilitation \\
\hline & Diagnosis = chronic low back pain \\
\hline & Mean years of pain $=$ not given (minimum 6 months) \\
\hline \multirow[t]{2}{*}{ Interventions } & "progressive intervention of intensive physical training and psychosocial activation AKSELI" \\
\hline & "control: less intensive physical training and passive physical therapies" \\
\hline \multirow[t]{2}{*}{ Outcomes } & Primary pain outcome: none \\
\hline & Primary disability outcome: none \\
\hline
\end{tabular}




\section{Primary mood outcome: BDI}

\section{Catastrophising outcome: none}

1. lumbar flexion-extension

2. lateral flexion

3. trunk rotation

4. hamstring tightness

5. number of sit-ups

6. number of arch-ups

7. static strength of back muscles

8. number of squats

9. Million index of pain and disability mean of 14 items rated 0 to 100

10. low back pain capacity 1 to 3

11. leisure activities physical intensity 0 to 10

12. number of visits to doctors (12-month follow-up)

13. number of physical therapy outpatient visits (12-month follow-up)

14. WHO occupational handicap 0 to 5

15. sick days

16. Beck Depression Inventory

17. Symptom Check List

18. Multidimensional Health Locus of Control

19. Social Adjustment Scale

20. Karolinska Scales of Personality

Notes

Excluded from 2009 review for marginal psychological content; included in 2012 update

No data

Yates quality scale: total quality $=16 / 35$, design quality $=13 / 26$, treatment quality $=3 / 9$

\section{Risk of bias}

\begin{tabular}{lll}
\hline Bias & Authors' judgement & Support for judgement \\
\hline $\begin{array}{l}\text { Random sequence genera- } \\
\text { tion (selection bias) }\end{array}$ & High risk & $\begin{array}{l}\text { "patients stratified according to age ... and sex and randomly divided into in- } \\
\text { tervention and control groups" }\end{array}$ \\
\hline $\begin{array}{l}\text { Allocation concealment } \\
\text { (selection bias) }\end{array}$ & High risk & $\begin{array}{l}\text { No information but post-randomisation exclusion of patients "not fit" for inter- } \\
\text { vention group }\end{array}$ \\
\hline $\begin{array}{l}\text { Incomplete outcome data } \\
\text { (attrition bias) } \\
\text { All outcomes }\end{array}$ & High risk & Attrition implied not reported; no reporting of differences \\
\hline
\end{tabular}


Alaranta 1994 (Continued)

Selective reporting (re- High risk Many outcomes not reported
porting bias)

Blinding of outcome assessment (detection bias) All outcomes
High risk

Self report and examination by physiatrist and physiotherapist at baseline and follow-up. No statement about blinding.

\section{Altmaier 1992}

\begin{tabular}{ll}
\hline Methods & RCT; 2 arms; assessed at pre-treatment, post-treatment, 6 months \\
\hline Participants & End of treatment $n=42$ \\
& Start of treatment $n=45$ \\
& Sex: $12 \mathrm{~F}, 33 \mathrm{M}$ \\
& Mean age $=39.9$ (SD 8.9) \\
& Source = pain and rehabilitation clinic \\
& Diagnosis = chronic low back pain \\
Mean years of pain = not given
\end{tabular}

\section{Outcomes}

\section{Primary pain outcome: MPQ PRI}

Primary disability outcome: WHYMPI pain interference

\section{Primary mood outcome: WHYMPI distress}

\section{Catastrophising outcome: none}

1. Primary aerobic impairment

2. Self efficacy

3. West Haven Yale Multidimensional Pain Inventory (WHYMPI) self control

4. West Haven Yale Multidimensional Pain Inventory (WHYMPI) pain interference

5. West Haven Yale Multidimensional Pain Inventory (WHYMPI) mood

6. Disability

7. Melzack Pain Questionnaire Pain Response Index (MPQ PRI)

Notes CBT versus TAU, post-treatment and follow-up: analyses 3.1, 3.2, 3,3, 4.1, 4.2, 4.3

Yates quality scale: total quality $=15 / 35$, design quality $=11 / 26$, treatment quality $=4 / 9$

\section{Risk of bias}


Altmaier 1992 (Continued)

$\begin{array}{lll}\begin{array}{l}\text { Random sequence genera- } \\ \text { tion (selection bias) }\end{array} & \text { High risk } & \begin{array}{l}\text { Abstract: "Forty-five low back pain patients were randomly assigned"; no de- } \\ \text { tails in Methods }\end{array}\end{array}$
tion (selection bias) tails in Methods

\begin{tabular}{lll}
\hline $\begin{array}{l}\text { Allocation concealment } \\
\text { (selection bias) }\end{array}$ & High risk & Not reported \\
\hline $\begin{array}{l}\text { Incomplete outcome data } \\
\text { (attrition bias) }\end{array}$ & High risk & Inadequately reported \\
All outcomes & &
\end{tabular}

\begin{tabular}{lll}
\hline $\begin{array}{l}\text { Selective reporting (re- } \\
\text { porting bias) }\end{array}$ & Low risk & Fully reported \\
\hline $\begin{array}{l}\text { Blinding of outcome as- } \\
\text { sessment (detection bias) } \\
\text { All outcomes }\end{array}$ & High risk & Not reported \\
\hline
\end{tabular}

\title{
Basler 1997
}

\begin{tabular}{ll}
\hline Methods & RCT; 2 arms; assessed at pre-treatment, post-treatment, 6 months \\
\hline Participants & End of treatment $n=76$ \\
& Start of treatment $n=94$ \\
& Sex: $57 \mathrm{~F}, 19 \mathrm{M}$ \\
& Mean age $=49.3$ (SD 9.7) \\
& Source = pain or rehabilitation clinic \\
& Diagnosis = chronic low back pain \\
Mean years of pain = 10.8 & "CBT added to medical treatment" \\
\hline Interventions & "Medical treatment" \\
\hline
\end{tabular}

Outcomes

\section{Primary pain outcome: NRS 0 to 10 pain}

Primary disability outcome: disability in physical function from Dusseldorf Disability Scale

\section{Primary mood outcome: none}

\section{Catastrophising outcome: PRSS catastrophising}

\author{
1. Pain Intensity Numerical Rating Scale (0 to 10) \\ 2. Control over pain Numerical Rating Scale (0 to 10) \\ 3. Days per week pain-free \\ 4. Days per week pain medication use \\ 5. Use of cognitive strategies (self report) \\ 6. Use of avoidance behaviour (self report) \\ 7. Pleasant activities (self report)
}


Basler 1997 (Continued)
8. Social support (self report)
9. Philosophical beliefs (self report)
10. Catastrophising (bespoke scale)
11. Active coping (bespoke scale)
12. Disability in social relationships from Dusseldorf Disability Scale
13. Disability in social roles from Dusseldorf Disability Scale
14. Disability in physical function from Dusseldorf Disability Scale
15. Disability in mental performance from Dusseldorf Disability Scale
16. Disability in physical performance from Dusseldorf Disability Scale

Notes

CBT versus TAU, post-treatment: analyses 3.1, 3.2

Yates quality scale: total quality $=18 / 35$, design quality $=12 / 26$, treatment quality $=6 / 9$

\section{Risk of bias}

\begin{tabular}{lll}
\hline Bias & Authors' judgement & Support for judgement \\
\hline $\begin{array}{l}\text { Random sequence genera- } \\
\text { tion (selection bias) }\end{array}$ & High risk & $\begin{array}{l}\text { "Through assignment of random numbers, patients were allocated to an ex- } \\
\text { perimental treatment or a control group." }\end{array}$ \\
\hline $\begin{array}{l}\text { Allocation concealment } \\
\text { (selection bias) }\end{array}$ & High risk & Not reported \\
\hline $\begin{array}{l}\text { Incomplete outcome data } \\
\text { (attrition bias) } \\
\text { All outcomes }\end{array}$ & Low risk & Attrition reported; 1 difference found between dropouts and completers \\
\hline $\begin{array}{l}\text { Selective reporting (re- } \\
\text { porting bias) }\end{array}$ & Low risk & Fully reported \\
\hline $\begin{array}{l}\text { Blinding of outcome as- } \\
\text { sessment (detection bias) } \\
\begin{array}{l}\text { All outcomes } \\
\hline\end{array}\end{array}$ & High risk & Not reported \\
\hline
\end{tabular}

Bliokas 2007

\begin{tabular}{ll}
\hline Methods & RCT; 3 arms; assessed at pretreatment and post-treatment \\
\hline Participants & End of treatment $n=94$ \\
& Start of treatment $n=143$ \\
& Sex: $79 \mathrm{~F}, 64 \mathrm{M}$ \\
& Mean age $=45.2$ (SD 9.2) \\
& Source = referrals to Pain Management Service after medical treatment completed \\
& Diagnosis = chronic non-cancer pain \\
Mean years of pain = median 4.0
\end{tabular}


Bliokas 2007 (Continued)

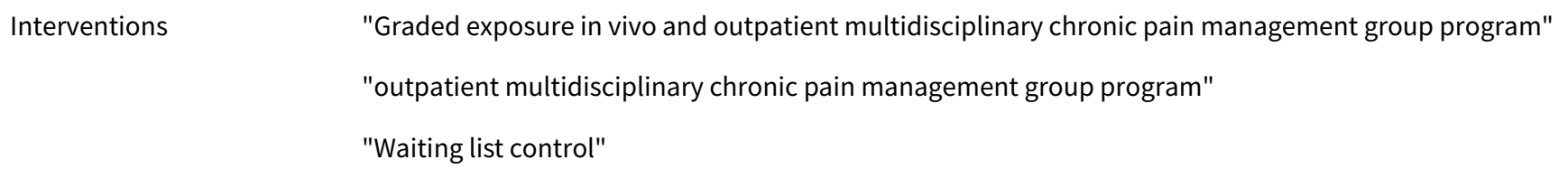

\section{Outcomes}

\section{Primary pain outcome: pain VAS}

\section{Primary disability outcome: Pain Disability Index}

\section{Primary mood outcome: DASS depression}

\section{Catastrophising outcome: none}

1. Pain VAS

2. Tampa Scale for Kinesiophobia: fear of movement/re/injury

3. Pain Self-Efficacy Questionnaire (PSEQ)

4. Pain Disability Index (PDI)

5. Depression, Anxiety \& Stress Scale (DASS): depression and anxiety scores only

6. Activity level: performance over 2 weeks of 10 usually avoided activities

7. 6-minute walk test

Notes

Chronic pain management programme with graded exposure versus waiting list control

December 2009 search

Data obtained from author: analyses 3.1, 3.2, 3.3

Yates quality scale: total quality $=23 / 35$, design quality $=15 / 26$, treatment quality $=8 / 9$

\section{Risk of bias}

\begin{tabular}{lll}
\hline Bias & Authors' judgement & Support for judgement \\
\hline $\begin{array}{l}\text { Random sequence genera- } \\
\text { tion (selection bias) }\end{array}$ & Low risk & Random numbers generation \\
\hline $\begin{array}{l}\text { Allocation concealment } \\
\text { (selection bias) }\end{array}$ & High risk & Not reported \\
\hline $\begin{array}{l}\text { Incomplete outcome data } \\
\text { (attrition bias) } \\
\text { All outcomes }\end{array}$ & Low risk & Attrition fully reported; no differences \\
\hline $\begin{array}{l}\text { Selective reporting (re- } \\
\text { porting bias) }\end{array}$ & Low risk & Fully reported \\
\hline $\begin{array}{l}\text { Blinding of outcome as- } \\
\text { sessment (detection bias) } \\
\text { All outcomes }\end{array}$ & High risk & Examination by physiotherapist and self report: no blinding reported \\
\hline
\end{tabular}


Buckelew 1998

\begin{tabular}{ll}
\hline Methods & RCT; 4 arms; assessed at pre-treatment, post-treatment, 3 months, 1 year, 2 years \\
\hline Participants & End of treatment $n=109$ \\
& Start of treatment $n=119$ \\
& Sex: $108 \mathrm{~F}, 11 \mathrm{M}$ \\
& Mean age $=44$ (SD 10) \\
& Source = mainly community \\
& Diagnosis = fibromyalgia \\
& Mean years of pain = 11.5 \\
"Biofeedback + relaxation + exercise" \\
"Biofeedback + relaxation" \\
"Exercise" \\
"Education attentional control"
\end{tabular}

\section{Outcomes}

Primary pain outcome: no data available

Primary disability outcome: no data available

Primary mood outcome: no data available

Catastrophising outcome: no data available

Arthritis Impact Measurement Scale: Physical Activity subscale (AIMS)

Symptom Checklist (SCL-90R) distress

Center for Epidemiologic Studies Depression Scale (CES-D)

Arthritis Self-Efficacy Scale

Sleep rating 0 to 12

Tender Point Index

Myalgic score

Physician's VAS rating of disease severity

Keefe \& Block Pain Behaviour: observation

\begin{tabular}{|c|c|}
\hline Notes & No data \\
\hline
\end{tabular}

\section{Risk of bias}

\begin{tabular}{lll}
\hline Bias & Authors' judgement & Support for judgement \\
\hline $\begin{array}{l}\text { Random sequence genera- } \\
\text { tion (selection bias) }\end{array}$ & High risk & "randomly assigned" \\
\hline $\begin{array}{l}\text { Allocation concealment } \\
\text { (selection bias) }\end{array}$ & High risk & Not reported \\
\hline
\end{tabular}


Buckelew 1998 (Continued)

\begin{tabular}{|c|c|c|}
\hline $\begin{array}{l}\text { Incomplete outcome data } \\
\text { (attrition bias) }\end{array}$ & Unclear risk & $\begin{array}{l}\text { Attrition partially reported and did not differ across groups; no test for differ- } \\
\text { ences }\end{array}$ \\
\hline
\end{tabular}

\begin{tabular}{lll}
\hline $\begin{array}{l}\text { Selective reporting (re- } \\
\text { porting bias) }\end{array}$ & Low risk & Fully reported \\
\hline $\begin{array}{l}\text { Blinding of outcome as- } \\
\text { sessment (detection bias) } \\
\text { All outcomes }\end{array}$ & Low risk & $\begin{array}{l}\text { Subjects examined by physician unaware of treatment conditions and with no } \\
\text { other contact with subjects }\end{array}$ \\
\hline
\end{tabular}

\section{De Souza 2008}

\begin{tabular}{ll}
\hline Methods & RCT; 2 arms; assessed at pre-treatment, post-treatment, 4 months, 12 months \\
\hline Participants & End of treatment $n=55$ \\
& Start of treatment $n=60$ \\
& Sex: $60 \mathrm{~F}, 0 \mathrm{M}$ \\
& Mean age $=49.6$ (SD 7.0) \\
& Source = not stated \\
& Diagnosis = fibromyalgia \\
& Mean years of pain = 12.4 \\
\hline Interventions & "Interactional School of Fibromyalgia" \\
"Control"
\end{tabular}

\section{Outcomes}

Primary pain outcome: MPI pain severity

Primary disability outcome: MPI interference with daily activity

Primary mood outcome: none

\section{Catastrophising outcome: none}
1. VAS pain (pain diary)
2. MPI pain severity
3. MPI pain interference daily activity
4. MPI control over pain
5. MPI mood
6. MPI family and social support
7. VAS suffering (pain diary)
8. VAS ability to do daily activity (pain diary)

Notes $\quad$ December 2009 search
No data


De Souza 2008 (Continued)

Yates quality scale: total quality $=13 / 35$, design quality $=10 / 26$, treatment quality $=3 / 9$

\section{Risk of bias}

\begin{tabular}{lll}
\hline Bias & Authors' judgement & Support for judgement \\
\hline $\begin{array}{l}\text { Random sequence genera- } \\
\text { tion (selection bias) }\end{array}$ & High risk & "randomly assigned" \\
\hline $\begin{array}{l}\text { Allocation concealment } \\
\text { (selection bias) }\end{array}$ & High risk & Not reported \\
\hline $\begin{array}{l}\text { Incomplete outcome data } \\
\text { (attrition bias) } \\
\text { All outcomes }\end{array}$ & High risk & Attrition partially reported; no test for differences \\
\hline $\begin{array}{l}\text { Selective reporting (re- } \\
\text { porting bias) }\end{array}$ & Low risk & Fully reported \\
\hline $\begin{array}{l}\text { Blinding of outcome as- } \\
\text { sessment (detection bias) } \\
\begin{array}{l}\text { All outcomes } \\
\hline\end{array}\end{array}$ & High risk & Not reported \\
\hline
\end{tabular}

Ehrenborg 2010

\begin{tabular}{|c|c|}
\hline Methods & RCT; 2 arms; assessed at post-treatment and 6-month follow-up \\
\hline \multirow[t]{7}{*}{ Participants } & End of treatment: $n=62$ \\
\hline & Start of treatment: $\mathrm{n}=65$ \\
\hline & Sex: 33 F, 29 M \\
\hline & Age: mean = $39.4($ SD 11.1) \\
\hline & Mean years of pain $=2.1(S D 2.5)$ \\
\hline & Source $=$ outpatient rehabilitation unit \\
\hline & Diagnosis = pain (neck and shoulder) after whiplash injury \\
\hline Interventions & CBT rehabilitation plus EMG biofeedback versus $\mathrm{CBT}$ rehabilitation \\
\hline \multirow[t]{6}{*}{ Outcomes } & Primary pain outcome: no data \\
\hline & Primary disability outcome: Canadian Occupational Performance Measure \\
\hline & Primary mood outcome: none \\
\hline & Catastrophising outcome: none \\
\hline & Canadian Occupational Performance Measure \\
\hline & Multi-dimensional Pain Inventory (Swedish) \\
\hline
\end{tabular}

Notes

CBT versus active, post-treatment and follow-up: analyses 1.2 and 2.2

2011 search 
Ehrenborg 2010 (Continued)

Yates quality scale: total quality $=21 / 35$, design quality $=17 / 26$, treatment quality $=4 / 9$

\section{Risk of bias}

Bias Authors' judgement Support for judgement

Random sequence genera- Unclear risk "Randomization was performed by casting a die after the participant's acception (selection bias) tance: odd numbers for treatment group ...."

\begin{tabular}{lll}
\hline $\begin{array}{l}\text { Allocation concealment } \\
\text { (selection bias) }\end{array}$ & High risk & Not reported \\
\hline $\begin{array}{l}\text { Incomplete outcome data } \\
\text { (attrition bias) }\end{array}$ & Low risk & Attrition fully reported \\
All outcomes & & \\
\hline
\end{tabular}

Selective reporting (re- Low risk $\quad$ Fully reported
porting bias)

\begin{tabular}{lll}
\hline Blinding of outcome as- & High risk & Therapists conducted assessments: statement that study not blinded \\
sessment (detection bias) & & \\
All outcomes &
\end{tabular}

All outcomes

\section{Ersek 2008}

\begin{tabular}{|c|c|}
\hline Methods & $\mathrm{RCT} ; 2$ arms; assessed at pretreatment, post-treatment, 6-month follow-up, 12-month follow-up \\
\hline \multirow[t]{7}{*}{ Participants } & End of treatment $n=218$ \\
\hline & Start of treatment $\mathrm{n}=256$ \\
\hline & Sex: $210 \mathrm{~F}, 46 \mathrm{M}$ \\
\hline & Mean age $=81.8($ SD 6.5) \\
\hline & Source $=$ residential retirement facilities \\
\hline & Diagnosis = pain more than 3 months; average last week $>2 / 10$ : mixed sites, largest legs and feet \\
\hline & Mean years of pain $=$ not given \\
\hline \multirow[t]{2}{*}{ Interventions } & "pain self-management training group (SMG) intervention" \\
\hline & "education only control condition" \\
\hline \multirow[t]{8}{*}{ Outcomes } & Primary pain outcome: BPI pain \\
\hline & Primary disability outcome: RMDQ \\
\hline & Primary mood outcome: Geriatric Depression Scale \\
\hline & Catastrophising outcome: CSQ catastrophising \\
\hline & 1. Roland \& Morris Disability Questionnaire \\
\hline & 2. Brief Pain Inventory: pain \\
\hline & 3. Brief Pain Inventory: interference with activity \\
\hline & 4. Geriatric Depression Scale \\
\hline
\end{tabular}


Ersek 2008 (Continued)
5. Arthritis Self-Efficacy Scale
6. CSQ catastrophising
7. Chronic Pain Coping Inventory: guarding
8. Chronic Pain Coping Inventory: resting
9. Chronic Pain Coping Inventory: asking for assistance
10. Chronic Pain Coping Inventory: relaxation
11. Chronic Pain Coping Inventory: task persistence
12. Chronic Pain Coping Inventory: exercise/stretch
13. Chronic Pain Coping Inventory: seeking support
14. Chronic Pain Coping Inventory: coping self statements
15. Chronic Pain Coping Inventory: pacing
16. Medication use: record

Notes

December 2009 search: 1.1, 1.2, 1.3, 1.4, 2.1, 2.2, 2.3, 2.4

Yates quality scale: total quality $=30 / 35$, design quality $=21 / 26$, treatment quality $=9 / 9$

\section{Risk of bias}

\begin{tabular}{lll}
\hline Bias & Authors' judgement & Support for judgement \\
\hline $\begin{array}{l}\text { Random sequence genera- } \\
\text { tion (selection bias) }\end{array}$ & Low risk & $\begin{array}{l}\text { Randomisation by (retirement) facility, by statistician using random number } \\
\text { generator }\end{array}$ \\
\hline $\begin{array}{l}\text { Allocation concealment } \\
\text { (selection bias) }\end{array}$ & Low risk & By independent statistician \\
\hline $\begin{array}{l}\text { Incomplete outcome data } \\
\begin{array}{l}\text { (attrition bias) } \\
\text { All outcomes }\end{array}\end{array}$ & Low risk & Fully reported attrition \\
\hline $\begin{array}{l}\text { Selective reporting (re- } \\
\text { porting bias) }\end{array}$ & Low risk & Fully reported \\
\hline $\begin{array}{l}\text { Blinding of outcome as- } \\
\text { sessment (detection bias) } \\
\begin{array}{l}\text { All outcomes } \\
\hline\end{array}\end{array}$ & High risk & Not reported \\
\hline
\end{tabular}

Evers 2002

\begin{tabular}{ll}
\hline Methods & RCT; 2 arms; assessed at pre-treatment, post-treatment, 6 months follow-up \\
\hline Participants & End of treatment $n=59$ \\
& Start of treatment $n=64$ \\
& Sex: $42 \mathrm{~F}, 17 \mathrm{M}$ \\
Mean age $=54.1$ (SD 11.4)
\end{tabular}


Evers 2002 (Continued)

$$
\begin{aligned}
& \text { Source = rheumatology clinic } \\
& \text { Diagnosis = rheumatoid arthritis } \\
& \text { Mean years of pain }=3.1
\end{aligned}
$$

\begin{tabular}{|c|c|}
\hline Interventions & $\begin{array}{l}\text { "Tailor made CBT" } \\
\text { "Treatment as usual" }\end{array}$ \\
\hline \multirow[t]{20}{*}{ Outcomes } & Primary pain outcome: IRGL Pain \\
\hline & Primary disability outcome: IRGL Functional Disability (Composite Z score) \\
\hline & Primary mood outcome: BDI depression \\
\hline & Catastrophising outcome: Illness Cognitions - Helplessness \\
\hline & Disease Activity \\
\hline & Invloed van Reuma op Gezondheid en Leefwijze (IRGL): Functional Disability \\
\hline & Invloed van Reuma op Gezondheid en Leefwijze (IRGL): Pain \\
\hline & Invloed van Reuma op Gezondheid en Leefwijze (IRGL): Anxiety \\
\hline & Invloed van Reuma op Gezondheid en Leefwijze (IRGL): Perceived support \\
\hline & Social network \\
\hline & Illness Cognitions: Helplessness \\
\hline & Illness Cognitions: Acceptance \\
\hline & Active Coping with Pain \\
\hline & Passive Coping with pain \\
\hline & Active Coping with Stress \\
\hline & Passive Coping with Stress \\
\hline & Fatigue \\
\hline & Beck Depression Inventory \\
\hline & Negative Mood (ZwartSpooren) \\
\hline & Medication compliance \\
\hline
\end{tabular}

Yates quality scale: total quality $=25 / 35$, design quality $=18 / 26$, treatment quality $=7 / 9$

\section{Risk of bias}

\begin{tabular}{lll}
\hline Bias & Authors' judgement & Support for judgement \\
\hline $\begin{array}{l}\text { Random sequence genera- } \\
\text { tion (selection bias) }\end{array}$ & Unclear risk & Random numbers \\
\hline $\begin{array}{l}\text { Allocation concealment } \\
\text { (selection bias) }\end{array}$ & Low risk & "previously determined" \\
\hline
\end{tabular}


Evers 2002 (Continued)
Incomplete outcome data
Low risk
Attrition fully reported
(attrition bias)

All outcomes

\begin{tabular}{lll}
\hline $\begin{array}{l}\text { Selective reporting (re- } \\
\text { porting bias) }\end{array}$ & Low risk & Fully reported
\end{tabular}

\begin{tabular}{lll}
\hline Blinding of outcome as- & High risk & Not reported \\
sessment (detection bias) & \\
All outcomes &
\end{tabular}

Falcao 2008

\begin{tabular}{|c|c|}
\hline Methods & $\mathrm{RCT} ; 2$ arms; assessed at pre-treatment, post-treatment, 3 months \\
\hline \multirow[t]{7}{*}{ Participants } & End of treatment $n=51$ \\
\hline & Start of treatment $n=60$ \\
\hline & Sex: $60 \mathrm{~F}, 0 \mathrm{M}$ \\
\hline & Mean age $=45.7($ SD 2.3) \\
\hline & Source $=$ Rheumatology outpatients \\
\hline & Diagnosis = fibromyalgia \\
\hline & Mean years of pain $=3.6$ \\
\hline \multirow[t]{2}{*}{ Interventions } & "Cognitive behavioral therapy" \\
\hline & "Routine medical visits" \\
\hline \multirow[t]{14}{*}{ Outcomes } & Primary pain outcome: VAS \\
\hline & Primary disability outcome: FIQ (no data for SF-36) \\
\hline & Primary mood outcome: BDI \\
\hline & Catastrophising outcome: none \\
\hline & 1. Visual analogue scale for pain \\
\hline & 2. Verbal improvement scale (5 categories) \\
\hline & 3. Fibromyalgia Impact Questionnaire (FIQ) \\
\hline & 4. SF-36 physical capacity (function) \\
\hline & 5. SF-36 physical aspects (role) \\
\hline & 6. SF-36 pain \\
\hline & 7. SF-36 general health \\
\hline & 8. SF-36 vitality \\
\hline & 9. SF-36 social aspects \\
\hline & 10. SF-36 emotional aspects \\
\hline
\end{tabular}


Falcao 2008 (Continued)

11. SF-36 mental health

12. Beck Depression Inventory (BDI)

13. Spielberger State-Trait Anxiety Inventory (STAI State)

14. Number of paracetamol tablets

Notes

December 2009 search: analyses 3.1, 3.2, 3.3

Yates quality scale: total quality $=16 / 35$, design quality $=14 / 26$, treatment quality $=2 / 9$

\section{Risk of bias}

\begin{tabular}{lll}
\hline Bias & Authors' judgement & Support for judgement \\
\hline $\begin{array}{l}\text { Random sequence genera- } \\
\text { tion (selection bias) }\end{array}$ & Unclear risk & "Patients were randomized by drawing lots" \\
\hline $\begin{array}{l}\text { Allocation concealment } \\
\text { (selection bias) }\end{array}$ & High risk & Not reported \\
\hline $\begin{array}{l}\text { Incomplete outcome data } \\
\begin{array}{l}\text { (attrition bias) } \\
\text { All outcomes }\end{array}\end{array}$ & Unclear risk & Attrition partially reported; statement that dropouts were not different \\
\hline $\begin{array}{l}\text { Selective reporting (re- } \\
\text { porting bias) }\end{array}$ & Low risk & Fully reported \\
\hline $\begin{array}{l}\text { Blinding of outcome as- } \\
\text { sessment (detection bias) } \\
\begin{array}{l}\text { All outcomes } \\
\hline\end{array}\end{array}$ & Low risk & Evaluation by clinician blind to treatment allocation \\
\hline
\end{tabular}

\section{Geraets 2005}

\begin{tabular}{ll}
\hline Methods & RCT; 2 arms; assessed at pre-treatment, post-treatment, 1 year \\
\hline Participants & End of treatment $n=158$ \\
& Start of treatment $n=176$ \\
& Sex: $109 \mathrm{~F}, 83 \mathrm{M}$ (at start of treatment) \\
& Mean age $=52.5$ (SD 12.4) \\
& Source = mixed community and volunteer \\
& Diagnosis = shoulder pain \\
& Mean years of pain = not given \\
\hline Interventions & "Graded exercise" \\
"Primary care TAU" \\
\hline Putcomes & Primary pain outcome: NRS \\
Primary mood outcome: none
\end{tabular}




\section{Catastrophising outcomes: PCCL catastrophising}

Shoulder disability questionnaire

Shoulder pain

Pain intensity NRS

Quality of life

Fear avoidance

Kinesiophobia ( 2 items)

Pain Coping and Cognition List: catastrophising

Pain Coping and Cognition List: coping

General Practitioner visits

Physician visits

Physiotherapy visits

Number of drug prescriptions

Number of days work absence

Total cost of health care (Euros)

Yates quality scale: total quality $=26 / 35$, design quality $=20 / 26$, treatment quality $=6 / 9$

\section{Risk of bias}

\begin{tabular}{lll} 
Bias & Authors' judgement & Support for judgement \\
\hline $\begin{array}{l}\text { Random sequence genera- } \\
\text { tion (selection bias) }\end{array}$ & Low risk & Block randomisation according to random number table \\
\hline $\begin{array}{l}\text { Allocation concealment } \\
\text { (selection bias) }\end{array}$ & Low risk & $\begin{array}{l}\text { Random number table generated by person not involved in study; opaque } \\
\text { sealed envelopes; "Blinding for patients .... of allocated treatment was not } \\
\text { possible" but treatment preferences elicited and shown to have no effect on } \\
\text { outcome }\end{array}$
\end{tabular}

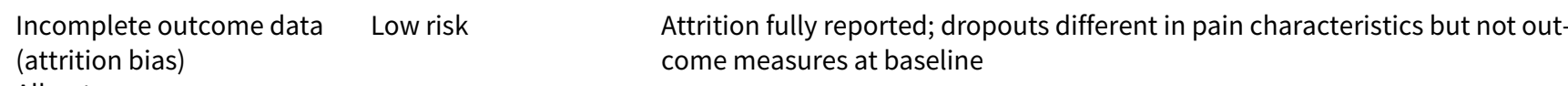

All outcomes

Attrition fully reported; dropouts different in pain characteristics but not out-

\begin{tabular}{lll}
\hline $\begin{array}{l}\text { Selective reporting (re- } \\
\text { porting bias) }\end{array}$ & Low risk & Fully reported \\
\hline $\begin{array}{l}\text { Blinding of outcome as- } \\
\text { sessment (detection bias) } \\
\text { All outcomes }\end{array}$ & Low risk & Researchers not involved in randomisation collect data \\
\hline
\end{tabular}


Glombiewski 2010b

\begin{tabular}{ll}
\hline Methods & RCT; 3 arms: CBT + biofeedback; CBT; waiting list control, post-treatment (WLC assigned to treatment \\
so no WLC at 6-month follow-up) & End of treatment: $\mathrm{n}=116$ \\
& Start of treatment: $\mathrm{n}=128$ \\
Participants & Sex: $77 \mathrm{~F}, 39 \mathrm{M}$ \\
& Mean age: 48.8 (SD 11.7) \\
& Source = medical referrals (86\%) or response to newspaper advert (14\%) \\
& Diagnosis = chronic back pain \\
Mean years of pain: 8.1 (SD 8.7) & "CBT with biofeedback" \\
"CBT" \\
"waiting list control"
\end{tabular}

Outcomes

Primary pain outcome: 0 to 10 NRS pain intensity

Primary disability outcome: PDI

Primary mood outcome: BDI

Catastrophising outcome: none

Pain intensity 0 to 10 NRS

Pain average of $4 x$ daily diary for 1 week

Pain Disability Index

Beck Depression Inventory

Coping Strategies Scale from FESV

Health-Related Life Satisfaction Scale

Global treatment change

Treatment satisfaction

(Adverse events noted from pain intensity and global treatment change)

Health care use: doctor visits for pain

Notes Combined (CBT + biofeedback and CBT) versus WLC: analyses 3.1, 3.2, 3.3

2011 update search

Yates quality scale: total quality $24 / 35$, design quality $17 / 26$, design quality $15 / 26$

\section{Risk of bias}

\section{Bias}

Authors' judgement Support for judgement

Random sequence genera- Low risk tion (selection bias) 
Glombiewski 2010b (Continued)

Allocation concealment Unclear risk "coordinated by the first author" before study
(selection bias)

\begin{tabular}{|c|c|c|}
\hline $\begin{array}{l}\text { Incomplete outcome data } \\
\text { (attrition bias) }\end{array}$ & Unclear risk & $\begin{array}{l}\text { Attrition fully reported; statement that dropout data will be reported else- } \\
\text { where }\end{array}$ \\
\hline
\end{tabular}

All outcomes

Selective reporting (re- Low risk $\quad$ Fully reported
porting bias)

\begin{tabular}{ll}
\hline Blinding of outcome as- & High risk \\
sessment (detection bias) & \\
All outcomes &
\end{tabular}

\section{Greco 2004}

\begin{tabular}{ll}
\hline Methods & RCT; 3 arms; assessed pre-treatment, post-treatment, 6/9 months \\
\hline Participants & End of treatment $n=80$ \\
& Start of treatment $n=92$ \\
& Sex: 87 F, 5 M (at start of treatment) \\
& Mean age $=47.3$ (SD 10.4) \\
& Source $=$ volunteers \\
& Diagnosis = SLE \\
Mean years of pain $=11$
\end{tabular}

Interventions

"CBT with biofeedback"

"Symptom monitoring and support"

"Treatment as usual"

Outcomes

Primary pain outcome: AIMS2 pain 0 to 10

Primary disability outcome: SF36 physical function (reversed)

Primary mood outcome: CES-D Depression

Catastrophising outcome: perceived stress

Arthritis Impact Measurement Scale (AIMS) 2: pain

Multidimensional Pain Inventory: interference

Center for Epidemiologic Studies Depression Scale (CES-D)

Arthritis Self-Efficacy

Perceived stress

Short Form 36 physical function

Fatigue severity

Global self assessment 
Greco 2004 (Continued)

Disease activity systemic lupus activity measure-revised (SLAM-R)

Systemic Lupus Erythematosus Disease Activity Index (SLEDAI)

Notes $\quad$ CBT versus active, post-treatment and follow-up: analyses 1.1, 1.2, 1.3, 2.1, 2.2, 2.3

CBT versus TAU, post-treatment and follow-up: analyses 3.1, 3.2, 3.3, 4.1, 4.2, 4.3

Yates quality scale: total quality $=25 / 35$, design quality $=20 / 26$, treatment quality $=5 / 9$

\section{Risk of bias}

\begin{tabular}{|c|c|c|}
\hline Bias & Authors' judgement & Support for judgement \\
\hline $\begin{array}{l}\text { Random sequence genera- } \\
\text { tion (selection bias) }\end{array}$ & Low risk & "assigned randomly, based on a software-generated randomization plan" \\
\hline $\begin{array}{l}\text { Allocation concealment } \\
\text { (selection bias) }\end{array}$ & High risk & Not reported, but equal credibility of treatments rated by participants \\
\hline $\begin{array}{l}\text { Incomplete outcome data } \\
\text { (attrition bias) } \\
\text { All outcomes }\end{array}$ & Unclear risk & Attrition fully reported; no test for differences \\
\hline $\begin{array}{l}\text { Selective reporting (re- } \\
\text { porting bias) }\end{array}$ & Low risk & Fully reported \\
\hline $\begin{array}{l}\text { Blinding of outcome as- } \\
\text { sessment (detection bias) } \\
\text { All outcomes }\end{array}$ & Low risk & Rheumatologist and researcher assessors masked to treatment assignment \\
\hline
\end{tabular}

\section{Haldorsen 1998}

\begin{tabular}{ll}
\hline Methods & RCT; 2 arms; assessed pre-treatment, 1 year \\
\hline Participants & End of treatment $n=387$ \\
& Start of treatment $n=469$ \\
& Sex: $298 \mathrm{~F}, 171 \mathrm{M}$ \\
& Mean age $=43$ (SD 10.6) \\
& Source = National Insurance system contact \\
& Diagnosis = mixed chronic pain \\
& Mean years of pain = not given \\
\hline Interventions & "Cognitive behaviour therapy" \\
"Treatment as usual" \\
\hline Primary pain outcome: VAS pain \\
Primary disability outcome: none \\
Primary mood outcome: HSCL distress \\
Catastrophising outcome: none
\end{tabular}


Haldorsen 1998 (Continued)

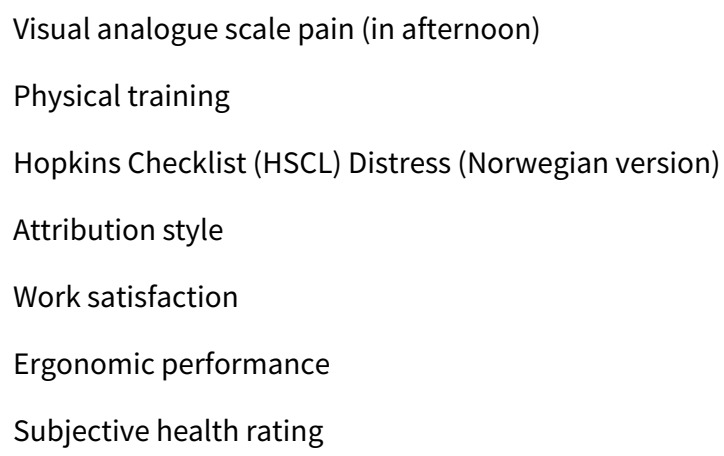

\section{Risk of bias}

\section{Bias}

\section{Authors' judgement Support for judgement}

Random sequence genera- Low risk Allocated at random by cards in sealed envelopes
tion (selection bias)

\begin{tabular}{l}
$\begin{array}{l}\text { Allocation concealment } \\
\text { (selection bias) }\end{array} \quad$ Low risk Allocation sequence by someone not involved in study \\
\hline
\end{tabular}

\begin{tabular}{ll}
\hline $\begin{array}{l}\text { Incomplete outcome data } \\
\text { (attrition bias) }\end{array}$ & High risk Attrition partially reported; no test for differences
\end{tabular}

All outcomes

Selective reporting (re- High risk Not fully reported
porting bias)

Blinding of outcome as-
sessment (detection bias) $\quad$ Unclear risk Assessment by physiotherapists who tried to remain blind to treatment
All outcomes

\section{Hammond 2001}

\begin{tabular}{ll}
\hline Methods & RCT; 2 arms; assessed at pre-treatment, post-treatment, 1 year \\
\hline Participants & End of treatment $n=121$ \\
& Start of treatment $n=127$ \\
& Sex: $97 \mathrm{~F}, 30 \mathrm{M}$ \\
& Mean age $=50.5$ (SD 10.6) \\
& Source = rheumatology clinic \\
& Diagnosis = rheumatoid arthritis (hand) \\
Mean years of pain = 1.6
\end{tabular}


"Standard arthritis education"

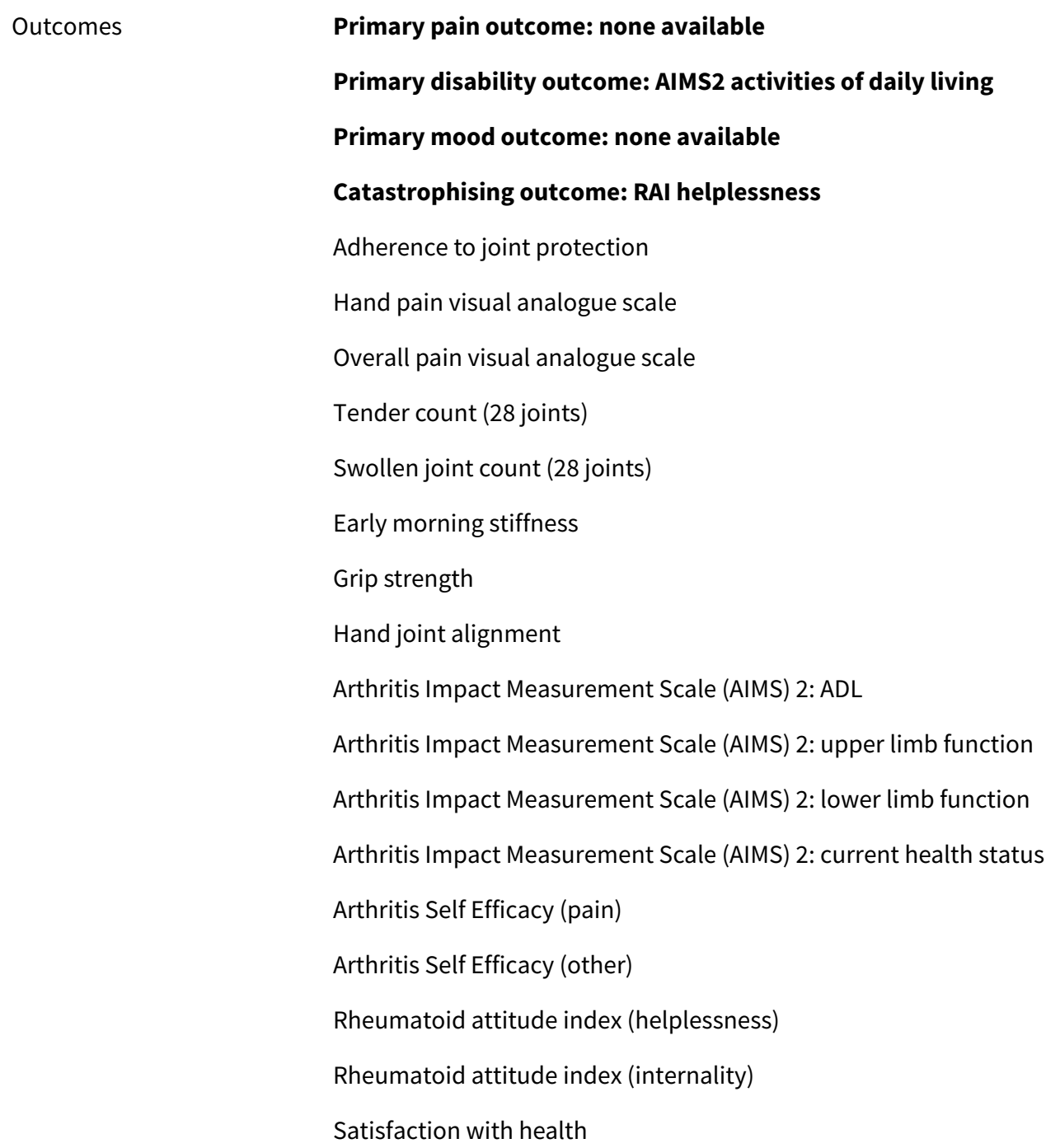

\section{Risk of bias}

\begin{tabular}{lll}
\hline Bias & Authors' judgement & Support for judgement \\
\hline $\begin{array}{l}\text { Random sequence genera- } \\
\text { tion (selection bias) }\end{array}$ & High risk & "allocated randomly" \\
\hline $\begin{array}{l}\text { Allocation concealment } \\
\text { (selection bias) }\end{array}$ & Low risk & Sealed envelopes prepared in advance \\
\hline $\begin{array}{l}\text { Incomplete outcome data } \\
\text { (attrition bias) } \\
\text { All outcomes }\end{array}$ & High risk & Attrition partially reported; no test for differences \\
\hline $\begin{array}{l}\text { Selective reporting (re- } \\
\text { porting bias) }\end{array}$ & Low risk & Fully reported \\
\hline \hline
\end{tabular}


Hammond 2001 (Continued)

$\begin{array}{lll}\text { Blinding of outcome as- } & \text { Low risk Independent assessor } \\ \text { sessment (detection bias) } & \end{array}$

All outcomes

\section{Jensen 1997}

\begin{tabular}{ll}
\hline Methods & RCT; 2 arms; assessed pre-treatment, post-treatment, 6 months, 18 months \\
\hline Participants & End of treatment $n=59$ \\
& Start of treatment $n=63$ \\
& Sex: $63 \mathrm{~F}, 0 \mathrm{M}$ (at start of treatment) \\
& Mean age $=43.4$ (SD 8.4) \\
& Source = pain or rehabilitation clinic \\
& Diagnosis = non-specific back or neck pain \\
Mean years of pain $=4.2$ \\
\hline Interventions & "Woman-specific CBT" \\
\hline
\end{tabular}

Outcomes

Primary pain outcome: VAS pain intensity

Primary disability outcome: Disability Rating Index

Primary mood outcome: BDI depression

Catastrophising outcome: RAI helplessness

Pain intensity visual analogue scale

Beck Depression Inventory (BDI)

Anxiety visual analogue scale

Disability Rating Index

Health perception numerical rating scale

Coping Strategies Questionnaire (CSQ)

Rheumatoid attitudes index (helplessness)

Notes CBT versus active, post-treatment and follow-up: analyses 1.1, 1.2, 1.3, 2.1, 2.2, 2.3

Yates quality scale: total quality $=16 / 35$, design quality $=13 / 26$, treatment quality $=3 / 9$

\section{Risk of bias}

\begin{tabular}{lll}
\hline Bias & Authors' judgement & Support for judgement \\
\hline $\begin{array}{l}\text { Random sequence genera- } \\
\text { tion (selection bias) }\end{array}$ & Unclear risk & Central randomisation using random numbers table \\
\hline
\end{tabular}




\section{Jensen 1997 (Continued)}

$\begin{aligned} & \text { Allocation concealment } \\ & \text { (selection bias) }\end{aligned}$
High risk Not reported

$\begin{array}{ll}\text { Incomplete outcome data High risk } & \text { Attrition partially reported; no test for differences } \\ \text { (attrition bias) }\end{array}$

All outcomes

\begin{tabular}{lll}
\hline $\begin{array}{l}\text { Selective reporting (re- } \\
\text { porting bias) }\end{array}$ & High risk & Partially reported \\
\hline $\begin{array}{l}\text { Blinding of outcome as- } \\
\text { sessment (detection bias) }\end{array}$ & Low risk & Assessors blind to treatment condition \\
\begin{tabular}{l} 
All outcomes \\
\hline
\end{tabular}
\end{tabular}

Jensen 2001

\begin{tabular}{ll}
\hline Methods & RCT; 4 arms; assessed at pre-treatment, post-treatment, 6 months, 18 months, 3 years \\
\hline Participants & End of treatment $n=186$ \\
& Start of treatment $n=214$ \\
& Sex: $117 \mathrm{~F}, 93 \mathrm{M}$ \\
& Mean age $=43.3$ (SD 10.4) \\
& Source = pain or rehabilitation clinic \\
& Diagnosis = mixed (mostly chronic low back pain) \\
& Mean years of pain = 2.7 \\
"CBT" & "Behavioural medicine rehabilitation" \\
"Behaviourally orientated physical therapy" (BT) \\
"Treatment as usual"
\end{tabular}

\begin{tabular}{ll}
\hline Outcomes & Primary pain outcome: SF36 pain (reversed) \\
Primary disability outcome: SF36 physical function (reversed) \\
Primary mood outcome: SF36 mental health (reversed) \\
Catastrophising outcomes: none
\end{tabular}

Short Form 36 Pain

Short Form 36 Physical Function

Short Form 36 Mental Health 


\section{Risk of bias}

\begin{tabular}{lll}
\hline Bias & Authors' judgement & Support for judgement \\
\hline $\begin{array}{l}\text { Random sequence genera- } \\
\text { tion (selection bias) }\end{array}$ & Unclear risk & Shuffled sealed envelopes \\
\hline $\begin{array}{l}\text { Allocation concealment } \\
\text { (selection bias) }\end{array}$ & Low risk & Sealed envelopes; procedure by researchers blind to participant screening \\
\hline $\begin{array}{l}\text { Incomplete outcome data } \\
\text { (attrition bias) } \\
\text { All outcomes }\end{array}$ & High risk & Partially reported; differential attrition; no test of differences \\
\hline $\begin{array}{l}\text { Selective reporting (re- } \\
\text { porting bias) }\end{array}$ & Low risk & Fully reported \\
\hline $\begin{array}{l}\text { Blinding of outcome as- } \\
\text { sessment (detection bias) } \\
\text { All outcomes }\end{array}$ & Unclear risk & Data gathered by research team \\
\hline
\end{tabular}

Kaapa 2006

\begin{tabular}{|c|c|}
\hline Methods & $\mathrm{RCT} ; 2$ arms; assessed at pre-treatment, post-treatment, 6 months, 1 year, 2 years \\
\hline \multirow[t]{7}{*}{ Participants } & End of treatment $n=120$ \\
\hline & Start of treatment $n=132$ \\
\hline & Sex: $120 \mathrm{~F}, 12 \mathrm{M}$ (start of treatment) \\
\hline & Mean age $=46.3($ SD 7.5$)$ \\
\hline & Source $=$ community \\
\hline & Diagnosis $=$ chronic low back pain \\
\hline & Mean years of pain $=1.3$ \\
\hline \multirow[t]{2}{*}{ Interventions } & "semi-intensive multidisciplinary rehabilitation" \\
\hline & "individual physiotherapy" \\
\hline \multirow[t]{8}{*}{ Outcomes } & Primary pain outcome: pain intensity 0 to 10 \\
\hline & Primary disability outcome: Oswestry Disability Index 0 to 100 \\
\hline & Primary mood outcome: (DEPS) depression 0 to 30 \\
\hline & Catastrophising outcome: none \\
\hline & Low back pain intensity 0 to 10 \\
\hline & Sciatic pain intensity 0 to 10 \\
\hline & Oswestry Disability Index 0 to 100 \\
\hline & Subjective work capacity 0 to 10 \\
\hline
\end{tabular}


Kaapa 2006 (Continued)

Recent sick leave due to back pain

Beliefs re working (2-year follow-up) 0 to 10

The Depression Scale (DEPS) 0 to 30

Health care consumption 12 months

Notes

CBT versus active, post-treatment and follow-up: analyses 1.1, 1.2, 1.3, 2.1, 2.2, 2.3

Yates quality scale: total quality $=23 / 35$, design quality $=20 / 26$, treatment quality $=3 / 9$

\section{Risk of bias}

\begin{tabular}{lll}
\hline Bias & Authors' judgement & Support for judgement \\
\hline $\begin{array}{l}\text { Random sequence genera- } \\
\text { tion (selection bias) }\end{array}$ & Low risk & Random numbers \\
\hline $\begin{array}{l}\text { Allocation concealment } \\
\text { (selection bias) }\end{array}$ & Low risk & Opaque sealed envelopes; numbers generated by independent statistician \\
\hline $\begin{array}{l}\text { Incomplete outcome data } \\
\text { (attrition bias) }\end{array}$ & Unclear risk & Fully reported; no test for differences \\
\hline $\begin{array}{l}\text { All outcomes } \\
\text { Selective reporting (re- }\end{array}$ & Low risk & Fully reported \\
\hline $\begin{array}{l}\text { Blinding of outcome as- } \\
\text { sessment (detection bias) } \\
\text { All outcomes }\end{array}$ & High risk & Not reported \\
\hline
\end{tabular}

Keefe 1990

\begin{tabular}{ll}
\hline Methods & RCT. 3 arms; assessed pre-treatment, post-treatment, 6 months \\
\hline Participants & End of treatment $\mathrm{n}=94$ \\
& Start of treatment $\mathrm{n}=99$ \\
& Sex: $71 \mathrm{~F}, 28 \mathrm{M}$ \\
& Mean age $=64.0$ (SD 11.5) \\
& Source = rheumatology clinic \\
& Diagnosis = osteoarthritis of the knee \\
& Mean years of pain = 12.0 \\
\hline Interventions & "coping skills training" \\
"arthritis education" & "standard care" \\
\hline Outcomes & Primary pain outcome: AIMS pain \\
\hline
\end{tabular}


Keefe 1990 (Continued)

\section{Primary mood outcome: AIMS psychological disability}

\section{Catastrophising outcome: none}

Arthritis Impact Measurement Scale (AIMS): pain

Arthritis Impact Measurement Scale (AIMS): psychological disability

Arthritis Impact Measurement Scale (AIMS): physical disability

Pain behaviour (Keefe \& Block) observation

Coping Strategy Questionnaire

Medication use

Notes

CBT versus active, post-treatment and follow-up: analyses 1.1, 1.2, 1.3, 2.1, 2.2, 2.3

CBT versus TAU, post-treatment and follow-up: analyses 3.1, 3.2, 3.3, 4.1, 4.2, 4.3

Yates quality scale: total quality $=26 / 35$, design quality $=18 / 26$, treatment quality $=8 / 9$

\section{Risk of bias}

\begin{tabular}{lll}
\hline Bias & Authors' judgement & Support for judgement \\
\hline $\begin{array}{l}\text { Random sequence genera- } \\
\text { tion (selection bias) }\end{array}$ & Unclear risk & "randomly assigned (using a random number table)" \\
\hline $\begin{array}{l}\text { Allocation concealment } \\
\text { (selection bias) }\end{array}$ & High risk & Not reported (but equal credibility of treatments rated by participants) \\
\hline $\begin{array}{l}\text { Incomplete outcome data } \\
\begin{array}{l}\text { (attrition bias) } \\
\text { All outcomes }\end{array}\end{array}$ & Low risk & Fully reported \\
\hline $\begin{array}{l}\text { Selective reporting (re- } \\
\text { porting bias) }\end{array}$ & Low risk & Fully reported \\
\hline $\begin{array}{l}\text { Blinding of outcome as- } \\
\text { sessment (detection bias) } \\
\begin{array}{l}\text { All outcomes } \\
\hline\end{array}\end{array}$ & High risk & Not reported \\
\hline
\end{tabular}

Keefe 1996

\begin{tabular}{ll}
\hline Methods & RCT; 3 arms; assessed at pre-treatment, post-treatment, 6 months, 1 year \\
\hline Participants & End of treatment $n=82$ \\
& Start of treatment $n=88$ \\
& Sex: $54 \mathrm{~F}, 34 \mathrm{M}$ \\
& Mean age $=62.6$ (SD 10.1) \\
& Source = volunteer \\
& Diagnosis = osteoarthritis of knee \\
& Mean years of pain $=10.7$
\end{tabular}


Keefe 1996 (Continued)

Interventions $\quad$ "spouse-assisted coping skills training"
"coping skills training"
"spouse-supported arthritis education"

\section{Outcomes}

\section{Primary pain outcome: AIMS pain}

Primary disability outcome: AIMS physical disability

Primary mood outcome: AIMS mental disability

\section{Catastrophising outcome: none}

Arthritis Impact Measurement Scale (AIMS): pain

Arthritis Impact Measurement Scale (AIMS): physical

Arthritis Impact Measurement Scale (AIMS): psychological

Coping Strategies Questionnaire: coping

Coping Strategies: pain control

Pain behaviour (Keefe \& Block) observation

\section{Notes}

CBT versus active, post-treatment: analyses 1.1, 1.2, 1.3

Yates quality scale: total quality $=25 / 35$, design quality $=17 / 26$, treatment quality $=8 / 9$

\section{Risk of bias}

\begin{tabular}{lll}
\hline Bias & Authors' judgement & Support for judgement \\
\hline $\begin{array}{l}\text { Random sequence genera- } \\
\text { tion (selection bias) }\end{array}$ & High risk & "randomly assigned" \\
\hline $\begin{array}{l}\text { Allocation concealment } \\
\text { (selection bias) }\end{array}$ & High risk & Not reported (but equal credibility of treatments rated by participants) \\
\hline $\begin{array}{l}\text { Incomplete outcome data } \\
\text { (attrition bias) } \\
\text { All outcomes }\end{array}$ & Unclear risk & Fully reported; no differential attrition but no test for differences \\
\hline $\begin{array}{l}\text { Selective reporting (re- } \\
\text { porting bias) }\end{array}$ & Low risk & Fully reported \\
\hline $\begin{array}{l}\text { Blinding of outcome as- } \\
\text { sessment (detection bias) } \\
\begin{array}{l}\text { All outcomes } \\
\hline\end{array}\end{array}$ & High risk & Not reported \\
\hline
\end{tabular}

Kole-Snijders 1999

\begin{tabular}{ll}
\hline Methods & RCT; 3 arms; assessed at pre-treatment, post-treatment, 6 months, 1 year \\
\hline Participants & End of treatment $n=133$ \\
Start of treatment $n=148$
\end{tabular}


Kole-Snijders 1999 (Continued)

Sex: $94 \mathrm{~F}, 54 \mathrm{M}$

Mean age $=30.8($ SD 9.1)

Source $=$ pain or rehabilitation clinic

Diagnosis = chronic low back pain

Mean years of pain $=9.8$

\begin{tabular}{l}
\hline Interventions $\quad$ "operant + cognitive coping skills" \\
"operant + group discussion" \\
"waiting list"
\end{tabular}

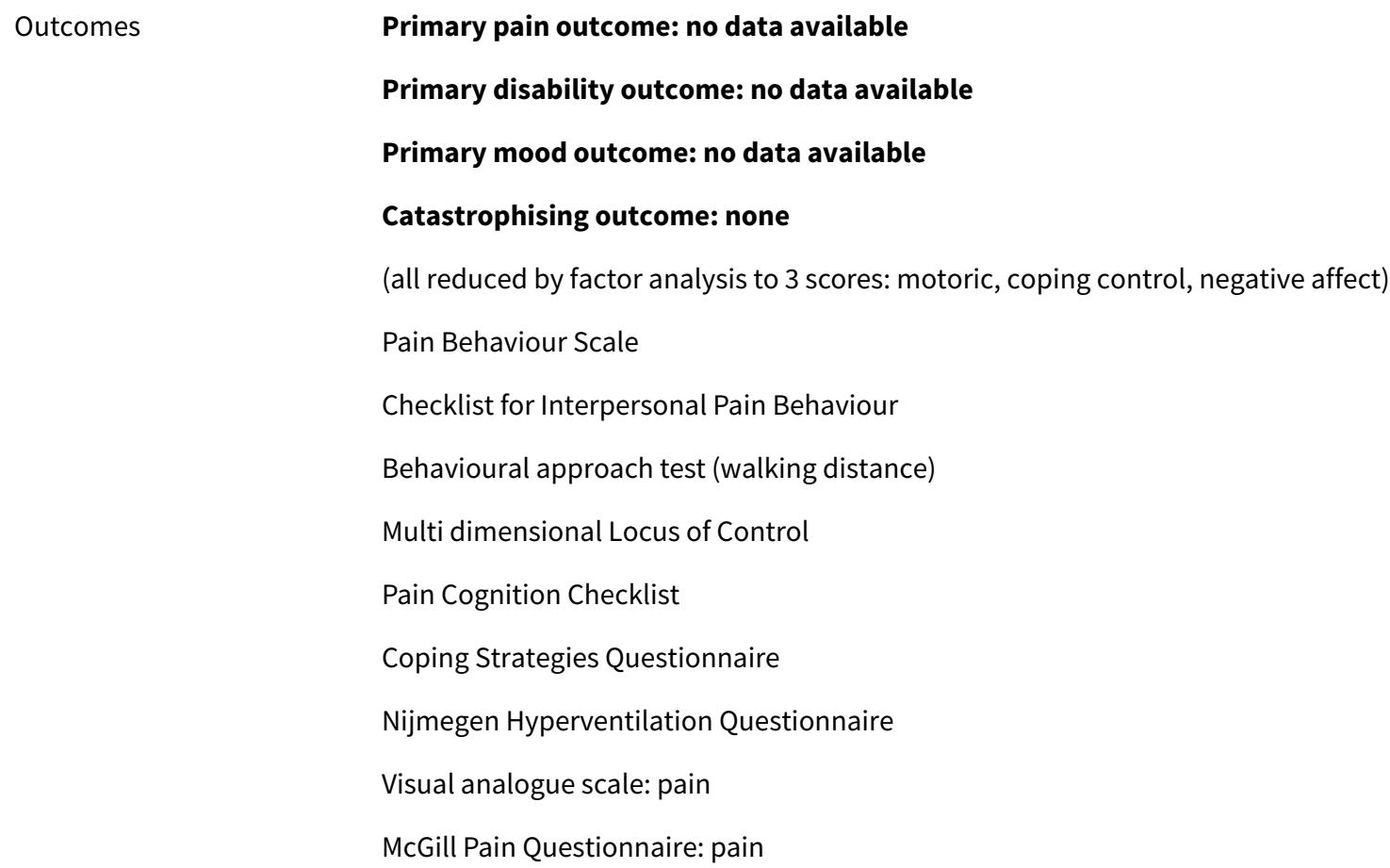

$\begin{array}{ll}\text { Notes } & \text { No data } \\ & \text { Yates quality scale: total quality }=28 / 35 \text {, design quality }=20 / 26, \text { treatment quality }=8 / 9\end{array}$

\section{Risk of bias}

\begin{tabular}{lll}
\hline Bias & Authors' judgement & Support for judgement \\
\hline $\begin{array}{l}\text { Random sequence genera- } \\
\text { tion (selection bias) }\end{array}$ & Unclear risk & $\begin{array}{l}\text { "independent researcher blindly drew [numbers assigned randomly to pa- } \\
\text { tients] and assigned to one of three conditions" }\end{array}$ \\
\hline $\begin{array}{l}\text { Allocation concealment } \\
\text { (selection bias) }\end{array}$ & Low risk & independent researcher \\
\hline $\begin{array}{l}\text { Incomplete outcome data } \\
\text { (attrition bias) } \\
\text { All outcomes }\end{array}$ & Low risk & Fully reported \\
\hline
\end{tabular}


Kole-Snijders 1999 (Continued)
Selective reporting (re-
Unclear risk
Reported as factor scores porting bias)

Blinding of outcome as-

Low risk

Assessor unaware of treatment condition

sessment (detection bias)

All outcomes

\section{Kraaimaat 1995}

\begin{tabular}{ll}
\hline Methods & RCT; 3 arms; assessed at pre-treatment, post-treatment, 6 months \\
\hline Participants & End of treatment $n=52$ \\
& Start of treatment $n=58$ \\
& Sex: 52 F, 25 M (from the 77 who agreed to participate) \\
& Mean age $=57.0$ (SD 12.7) \\
& Source = rheumatology clinics \\
& Diagnosis = rheumatoid arthritis \\
Mean years of pain = 15.6 & "cognitive behavioural therapy" \\
"occupational therapy" & "waiting list"
\end{tabular}

Outcomes

Primary pain outcome: IRGL pain

Primary disability outcome: IRGL function (Reversed)

Primary mood outcome: IRGL depression

Catastrophising outcome: none

Invloed van Reuma op Gezondheid en Leefwijze (IRGL): function

Invloed van Reuma op Gezondheid en Leefwijze (IRGL): self care

Invloed van Reuma op Gezondheid en Leefwijze (IRGL): pain

Invloed van Reuma op Gezondheid en Leefwijze (IRGL): anxiety

Invloed van Reuma op Gezondheid en Leefwijze (IRGL): depression

Invloed van Reuma op Gezondheid en Leefwijze (IRGL): potential support

Invloed van Reuma op Gezondheid en Leefwijze (IRGL): actual support

Invloed van Reuma op Gezondheid en Leefwijze (IRGL): mutual visits

Notes

CBT versus active, post-treatment and follow-up: analyses 1.1, 1.2, 1.3, 2.1, 2.2, 2.3

CBT versus TAU, post-treatment and follow-up: $\mathrm{N}<20$

Yates quality scale: total quality $=21 / 35$, design quality $=14 / 26$, treatment quality $=7 / 9$ 
Kraaimaat 1995 (Continued)

\section{Risk of bias}

\begin{tabular}{lll}
\hline Bias & Authors' judgement & Support for judgement \\
\hline $\begin{array}{l}\text { Random sequence genera- } \\
\text { tion (selection bias) }\end{array}$ & High risk & "randomly assigned" \\
\hline $\begin{array}{l}\text { Allocation concealment } \\
\text { (selection bias) }\end{array}$ & High risk & Not reported \\
\hline $\begin{array}{l}\text { Incomplete outcome data } \\
\text { (attrition bias) } \\
\text { All outcomes }\end{array}$ & Unclear risk & Fully reported; several differences between dropouts and completers \\
\hline $\begin{array}{l}\text { Selective reporting (re- } \\
\text { porting bias) }\end{array}$ & Low risk & Fully reported \\
\hline $\begin{array}{l}\text { Blinding of outcome as- } \\
\text { sessment (detection bias) } \\
\text { All outcomes }\end{array}$ & High risk & Not reported \\
\hline
\end{tabular}

\section{Leeuw 2008}

\begin{tabular}{ll}
\hline Methods & $\begin{array}{l}\text { RCT; } 2 \text { arms; assessed at } 2 \text { pre-treatment occasions, post-treatment, 6-month follow-up, 12-month fol- } \\
\text { low-up }\end{array}$ \\
\hline Participants & End of treatment $n=77$ \\
& Start of treatment $n=85$ \\
& Sex: $41 \mathrm{~F}, 44 \mathrm{M}$ \\
& Mean age $=45.3$ (SD 9.5) \\
& Source = rehabilitation clinics, occupational health, pain department \\
& Diagnosis = back pain (and at least moderate fear on TSK) \\
Mean years of pain = 9 & "Exposure in vivo" \\
"Operant graded activity"
\end{tabular}

Outcomes

\section{Primary pain outcome: MPQ pain intensity \\ Primary disability outcome: Quebec Back Pain Disability Scale (Dutch version) \\ Primary mood outcome: none}

Catastrophising outcome: PCS

1. Quebec Back Pain Disability Scale (Dutch version)

2. Patient Specific Complaints: VAS 0 to 100 of difficulty with 3 activities

3. Perceived harmfulness of activities (PHODA)

4. Pain Catastrophizing Scale: catastrophising 
Leeuw 2008 (Continued)
5. Daily activity: actimeter
6. Pain: mean of VAS 0 to 100 scales for current, worst and least pain

\begin{tabular}{ll}
\hline Notes & December 2009 search \\
& Exposure in vivo versus operant graded activity: analyses $5.1,5.2,5.4,6.1,6.2,6.4$ \\
& Yates quality scale: total quality $=32 / 35$, design quality $=24 / 26$, treatment quality $=8 / 9$ \\
\hline
\end{tabular}

\section{Risk of bias}

\begin{tabular}{|c|c|c|}
\hline Bias & Authors' judgement & Support for judgement \\
\hline $\begin{array}{l}\text { Random sequence genera- } \\
\text { tion (selection bias) }\end{array}$ & Low risk & "predetermined and computer-generated randomization schedule" \\
\hline $\begin{array}{l}\text { Allocation concealment } \\
\text { (selection bias) }\end{array}$ & Low risk & Sealed envelope; research assistant only could access randomization schedule \\
\hline $\begin{array}{l}\text { Incomplete outcome data } \\
\text { (attrition bias) } \\
\text { All outcomes }\end{array}$ & Low risk & Fully reported \\
\hline $\begin{array}{l}\text { Selective reporting (re- } \\
\text { porting bias) }\end{array}$ & Low risk & Fully reported \\
\hline $\begin{array}{l}\text { Blinding of outcome as- } \\
\text { sessment (detection bias) } \\
\text { All outcomes }\end{array}$ & Low risk & Electronic administration of assessments \\
\hline
\end{tabular}

\section{Lindell 2008}

\begin{tabular}{ll}
\hline Methods & RCT; 2 arms; assessed at pre-treatment, post-treatment, 18-month follow-up \\
\hline Participants & End of treatment $n=123$ \\
& Start of treatment $n=125$ \\
& Sex: $68 \mathrm{~F}, 57 \mathrm{M}$ \\
& Mean age = 42.6 (SD not given) \\
& Source = primary care \\
& Diagnosis = non-specific back or neck pain \\
& Mean years of pain = not given but had to be sick listed for more than 6 weeks up to 2 years; mean over \\
& 7 months sick listed \\
\hline Interventions & "Cognitive-behavioural rehabilitation" \\
& "Primary care" \\
\hline Outcomes & Primary pain outcome: none \\
Primary disability outcome: none \\
Primary mood outcome: none
\end{tabular}


Lindell 2008 (Continued)

\section{Catastrophising outcome: none}

1. Sick listed days

2. Healthcare visits

Notes
No data available
Yates quality scale: total quality $=18 / 35$, design quality $=16 / 26$, treatment quality $=2 / 6$

\section{Risk of bias}

\begin{tabular}{|c|c|c|}
\hline Bias & Authors' judgement & Support for judgement \\
\hline $\begin{array}{l}\text { Random sequence genera- } \\
\text { tion (selection bias) }\end{array}$ & Low risk & Computerised block randomisation procedure \\
\hline $\begin{array}{l}\text { Allocation concealment } \\
\text { (selection bias) }\end{array}$ & Low risk & Randomisation generated by independent statistician; in opaque envelopes \\
\hline $\begin{array}{l}\text { Incomplete outcome data } \\
\text { (attrition bias) } \\
\text { All outcomes }\end{array}$ & Unclear risk & Fully reported; no test for differences \\
\hline $\begin{array}{l}\text { Selective reporting (re- } \\
\text { porting bias) }\end{array}$ & Low risk & Fully reported \\
\hline $\begin{array}{l}\text { Blinding of outcome as- } \\
\text { sessment (detection bias) } \\
\text { All outcomes }\end{array}$ & High risk & Assessors not blind to treatment condition, except for sick listing outcome \\
\hline
\end{tabular}

Litt 2009

\begin{tabular}{ll}
\hline Methods & RCT; 2 arms; CBT + standard treatment; standard treatment; post-treatment \\
\hline Participants & End of treatment: $\mathrm{n}=54$ \\
& Start of treatment: $\mathrm{n}=54$ \\
& Sex: $46 \mathrm{~F} ; 8 \mathrm{M}$ \\
& Mean age: 41.0 (SD 11.0) \\
& Source = dental clinics and dentists (15\%); newspaper and web adverts (85\%) \\
& Diagnosis = temporomandibular disorder \\
& Mean years of pain: 5.6 (SD 5.4) \\
\hline CBT + standard treatment; standard treatment (splint, diet, NSAIDs) \\
\hline Primary pain outcome: MPI 0 to 6 \\
Primary disability outcome: interference MPI 0 to 6 \\
Primary mood outcome: CES-D \\
Catastrophising outcome: data not available
\end{tabular}


Litt 2009 (Continued)

Pain Intensity MPI 0 to 6

CES-D Depression

Interference with activity MPI 0 to 6

2 items modified from Catastrophising Sub-Scale CSQ

Several times daily sampling of pain, control, affect, coping, catastrophising

Notes

CBT versus TAU: analyses 3.1, 3.2, 3.3

2011 update search

Yates quality scale: total quality $14 / 35$, design quality $11 / 26$, treatment quality $3 / 9$

\section{Risk of bias}

\begin{tabular}{lll}
\hline Bias & Authors' judgement & Support for judgement \\
\hline $\begin{array}{l}\text { Random sequence genera- } \\
\text { tion (selection bias) }\end{array}$ & Low risk & Computerised urn randomisation \\
\hline $\begin{array}{l}\text { Allocation concealment } \\
\text { (selection bias) }\end{array}$ & High risk & Not reported \\
\hline $\begin{array}{l}\text { Incomplete outcome data } \\
\text { (attrition bias) } \\
\text { All outcomes }\end{array}$ & High risk & Attrition not reported \\
\hline $\begin{array}{l}\text { Selective reporting (re- } \\
\text { porting bias) }\end{array}$ & Low risk & Fully reported \\
\hline $\begin{array}{l}\text { Blinding of outcome as- } \\
\text { sessment (detection bias) } \\
\text { All outcomes }\end{array}$ & High risk & Not reported \\
\hline
\end{tabular}

\section{McCarberg 1999}

\begin{tabular}{ll}
\hline Methods & RCT; 2 arms; assessed pre-treatment, 6 months follow-up \\
\hline Participants & End of treatment $n=245$ \\
& Start of treatment $\mathrm{n}=353$ \\
& Sex: $264 \mathrm{~F}, 89 \mathrm{M}$ \\
& Mean age $=52.1$ (SD 9.6) \\
& Source = pain or rehabilitation clinic \\
& Diagnosis = mixed chronic pain, many chronic low back pain \\
& Mean years of pain = 9.6 \\
\hline Interventions & "Cognitive behaviour therapy" \\
\hline Outcomes & Prinimal home study" \\
\hline
\end{tabular}




\title{
Primary disability outcome: MPI pain interference
}

Primary mood outcome: MPI affective distress

\section{Catastrophising outcome: none}

11-point box scale: pain severity

Pain discomfort scale: pain distress

Multidimensional Pain Inventory: pain severity

Multidimensional Pain Inventory: affective distress

Multidimensional Pain Inventory: self control

Multidimensional Pain Inventory: interference

Multidimensional Pain Inventory: social support and spouse behaviour subscales

Notes

CBT versus active, follow-up: analyses 2.1, 2.2, 2.3

Yates quality scale: total quality $=11 / 35$, design quality $=9 / 26$, treatment quality $=2 / 9$

\section{Risk of bias}

\begin{tabular}{|c|c|c|}
\hline Bias & Authors' judgement & Support for judgement \\
\hline $\begin{array}{l}\text { Random sequence genera- } \\
\text { tion (selection bias) }\end{array}$ & Unclear risk & "Patients were randomized using a computer-generated random number list" \\
\hline $\begin{array}{l}\text { Allocation concealment } \\
\text { (selection bias) }\end{array}$ & High risk & Not reported \\
\hline $\begin{array}{l}\text { Incomplete outcome data } \\
\text { (attrition bias) } \\
\text { All outcomes }\end{array}$ & Unclear risk & No attrition during treatment, only at follow-up; no test for differences \\
\hline $\begin{array}{l}\text { Selective reporting (re- } \\
\text { porting bias) }\end{array}$ & Low risk & Fully reported \\
\hline $\begin{array}{l}\text { Blinding of outcome as- } \\
\text { sessment (detection bias) } \\
\text { All outcomes }\end{array}$ & High risk & Not reported \\
\hline
\end{tabular}

Mishra 2000

Methods $\quad$ RCT; 4 arms; assessed at pre-treatment, post-treatment

Participants

\author{
End of treatment $\mathrm{n}=94$ \\ Start of treatment $\mathrm{n}=94$ \\ Sex: $77 \mathrm{~F}, 7 \mathrm{M}$ \\ Mean age $=35.8($ SD 9.9) \\ Source $=$ pain or rehabilitation clinic and volunteer \\ Diagnosis = temporomandibular joint disorder
}


Mishra 2000 (Continued)

Mean years of pain $=7.0$

Interventions
"Biofeedback" (BT)
"Cognitive behavioural skills training" (CBT)
"no treatment control"

Primary pain outcome: CPI pain index
Primary disability outcome: none available
Primary mood outcome: none available
Catastrophising outcomes: none
Characteristic Pain Index (CPI) pain severity 0 to 100
Graded Chronic Pain Score
Profile of Mood States total

Notes

CBT versus TAU, post-treatment: analysis 3.1

BT versus TAU, post-treatment: analysis 7.1

Yates quality scale: total quality $=19 / 35$, design quality $=12 / 26$, treatment quality $=7 / 9$

\section{Risk of bias}

\begin{tabular}{lll}
\hline Bias & Authors' judgement & Support for judgement \\
\hline $\begin{array}{l}\text { Random sequence genera- } \\
\text { tion (selection bias) }\end{array}$ & High risk & $\begin{array}{l}\text { "patients were assigned to group in a semi-random fashion using the urn } \\
\text { method of random assignment" }\end{array}$ \\
\hline $\begin{array}{l}\text { Allocation concealment } \\
\text { (selection bias) }\end{array}$ & High risk & Not reported \\
\hline $\begin{array}{l}\text { Incomplete outcome data } \\
\begin{array}{l}\text { (attrition bias) } \\
\text { All outcomes }\end{array}\end{array}$ & High risk & Attrition not reported \\
\hline $\begin{array}{l}\text { Selective reporting (re- } \\
\text { porting bias) }\end{array}$ & High risk & Partially reported \\
\hline $\begin{array}{l}\text { Blinding of outcome as- } \\
\text { sessment (detection bias) } \\
\text { All outcomes }\end{array}$ & High risk & Not reported \\
\hline
\end{tabular}

Nicassio 1997

\begin{tabular}{ll}
\hline Methods & RCT; 2 arms; assessed at pre-treatment, post-treatment, 6 months \\
\hline Participants & End of treatment $n=71$ \\
& Start of treatment $n=96$ \\
& Sex: 63 F, 8 M (at follow-up) \\
\hline
\end{tabular}


Nicassio 1997 (Continued)

Mean age $=53.1($ SD no given $)$

Source $=$ pain or rehabilitation clinic, support groups

Diagnosis = fibromyalgia

Mean years of pain $=11.1$

\begin{tabular}{ll}
\hline Interventions & $\begin{array}{l}\text { "behavioural treatment" } \\
\text { "education" }\end{array}$ \\
\hline Outcomes & Primary pain outcome: not available \\
& Primary disability outcome: quality of well being \\
& Primary mood outcome: CES-D Depression \\
& Catastrophising outcome: RAI helplessness
\end{tabular}

Pain index: composite of Fibromyalgia Impact Questionnaire pain scale, MPQ PRI, number of body areas, and flare index

Pain Behavior Checklist self reported pain behaviour

Pain behaviour (Keefe \& Block) observation

Center for Epidemiologic Studies Depression Scale (CES-D)

Rheumatology Attitudes Index helplessness subscale

Pain Management Inventory active and passive coping

Quality of Well being Scale QWB: structured interview on functional impairment

Quality of Social Support Scale

Myalgia score, nurse rated on examination

Notes

BT versus active, post-treatment and follow-up: analyses 5.2, 5.3, 6.2, 6.3

Yates quality scale: total quality $=21 / 35$, design quality $=15 / 26$, treatment quality $=6 / 9$

\section{Risk of bias}

\begin{tabular}{lll}
\hline Bias & Authors' judgement & Support for judgement \\
\hline $\begin{array}{l}\text { Random sequence genera- } \\
\text { tion (selection bias) }\end{array}$ & Unclear risk & In blocks, "randomly assigned, using a random numbers table" \\
\hline
\end{tabular}

Allocation concealment $\quad$ High risk Not reported, though credibility ratings equal across treatments
(selection bias)

Incomplete outcome data Low risk Attrition fully reported; differential attrition across groups; no differences
(attrition bias)

(attrition bias)

All outcomes

Selective reporting (re- Low risk $\quad$ Fully reported
porting bias)

\begin{tabular}{lll}
\hline $\begin{array}{l}\text { Blinding of outcome as- } \\
\text { sessment (detection bias) }\end{array}$ & High risk $\quad$ Not reported \\
& \\
\hline
\end{tabular}


Nicassio 1997 (Continued)

All outcomes

Parker 1988

\begin{tabular}{ll}
\hline Methods & RCT; 3 arms; assessed at pre-treatment, 6 months, 1 year \\
\hline Participants & End of treatment $n=83$ \\
& Start of treatment $n=$ not given \\
& Sex: $3 \mathrm{~F}, 80 \mathrm{M}$ \\
& Mean age $=60.6$ (SD 7.7) \\
& Source = hospital \\
& Diagnosis = rheumatoid arthritis \\
Mean years of pain = 11.4 \\
\hline "cognitive behavioural pain management group" \\
"attention placebo group" \\
"control group" (TAU)
\end{tabular}

Outcomes

Primary pain outcome: no data available

Primary disability outcome: no data available

Primary mood outcome: no data available

Catastrophising outcome: none

Visual analogue scale pain

McGill Pain Questionnaire pain dimensions

Coping Strategies Questionnaire

Arthritis Impact Measurement Scale (AIMS)

Beck Depression Inventory

Symptom Checklist-90R psychological symptoms

Hassles Scale

Ways of Coping Questionnaire

Arthritis Helplessness Index

Disease status measures including walking speed

$\begin{array}{ll}\text { Notes } & \text { No data } \\ & \text { Yates quality scale: total quality }=17 / 35 \text {, design quality }=13 / 26 \text {, treatment quality }=4 / 9\end{array}$

\section{Risk of bias}

\section{Bias}

Authors' judgement Support for judgement 
Parker 1988 (Continued)

Random sequence genera- High risk "using a table of random numbers, subjects were assigned"
tion (selection bias)



\begin{tabular}{lll}
\hline $\begin{array}{l}\text { Allocation concealment } \\
\text { (selection bias) }\end{array}$ & High risk & Not reported \\
\hline $\begin{array}{l}\text { Incomplete outcome data } \\
\text { (attrition bias) }\end{array}$ & High risk & Attrition not reported
\end{tabular}

All outcomes

\begin{tabular}{lll}
\hline $\begin{array}{l}\text { Selective reporting (re- } \\
\text { porting bias) }\end{array}$ & High risk & Partially reported \\
\hline $\begin{array}{l}\text { Blinding of outcome as- } \\
\text { sessment (detection bias) } \\
\text { All outcomes }\end{array}$ & High risk & \\
\hline
\end{tabular}

\section{Puder 1988}

\begin{tabular}{ll}
\hline Methods & RCT; 2 arms; assessed at pre-treatment, post-treatment, 1 month \\
\hline Participants & End of treatment $n=69$ \\
& Start of treatment $n=71$ \\
& Sex: $49 \mathrm{~F}, 20 \mathrm{M}$ \\
& Mean age $=52.7$ (SD 14.4) \\
& Source = community \\
& Diagnosis = mixed chronic pain \\
Mean years of pain = 10.0 & "Cognitive behaviour therapy" \\
\hline Interventions & "waiting list"
\end{tabular}

\section{Outcomes}

\section{Primary pain outcome: pain diary}

\section{Primary disability outcome: pain interference}

\section{Primary mood outcome: none available}

\section{Catastrophising outcome: none}

Pain diary 0 to 5: highest and lowest ratings

Pain interference 0 to 5

Coping 0 to 5

Medication use

\section{Notes}

CBT versus TAU, post-treatment: analyses 3.1, 3.2

Yates quality scale: total quality $=13 / 35$, design quality $=10 / 26$, treatment quality $=3 / 9$ 
Puder 1988 (Continued)

\section{Risk of bias}

\begin{tabular}{|c|c|c|}
\hline Bias & Authors' judgement & Support for judgement \\
\hline $\begin{array}{l}\text { Random sequence genera- } \\
\text { tion (selection bias) }\end{array}$ & High risk & “randomly assigned" \\
\hline $\begin{array}{l}\text { Allocation concealment } \\
\text { (selection bias) }\end{array}$ & High risk & Not reported \\
\hline $\begin{array}{l}\text { Incomplete outcome data } \\
\text { (attrition bias) } \\
\text { All outcomes }\end{array}$ & Unclear risk & Attrition reported; no test for differences \\
\hline $\begin{array}{l}\text { Selective reporting (re- } \\
\text { porting bias) }\end{array}$ & High risk & Partially reported \\
\hline $\begin{array}{l}\text { Blinding of outcome as- } \\
\text { sessment (detection bias) } \\
\text { All outcomes }\end{array}$ & High risk & Not reported \\
\hline
\end{tabular}

\section{Schmidt 2011}

\section{Methods}

RCT; 3 arms; mindfulness-based stress reduction, active relaxation control, waiting list; post-treatment, 2-month follow-up

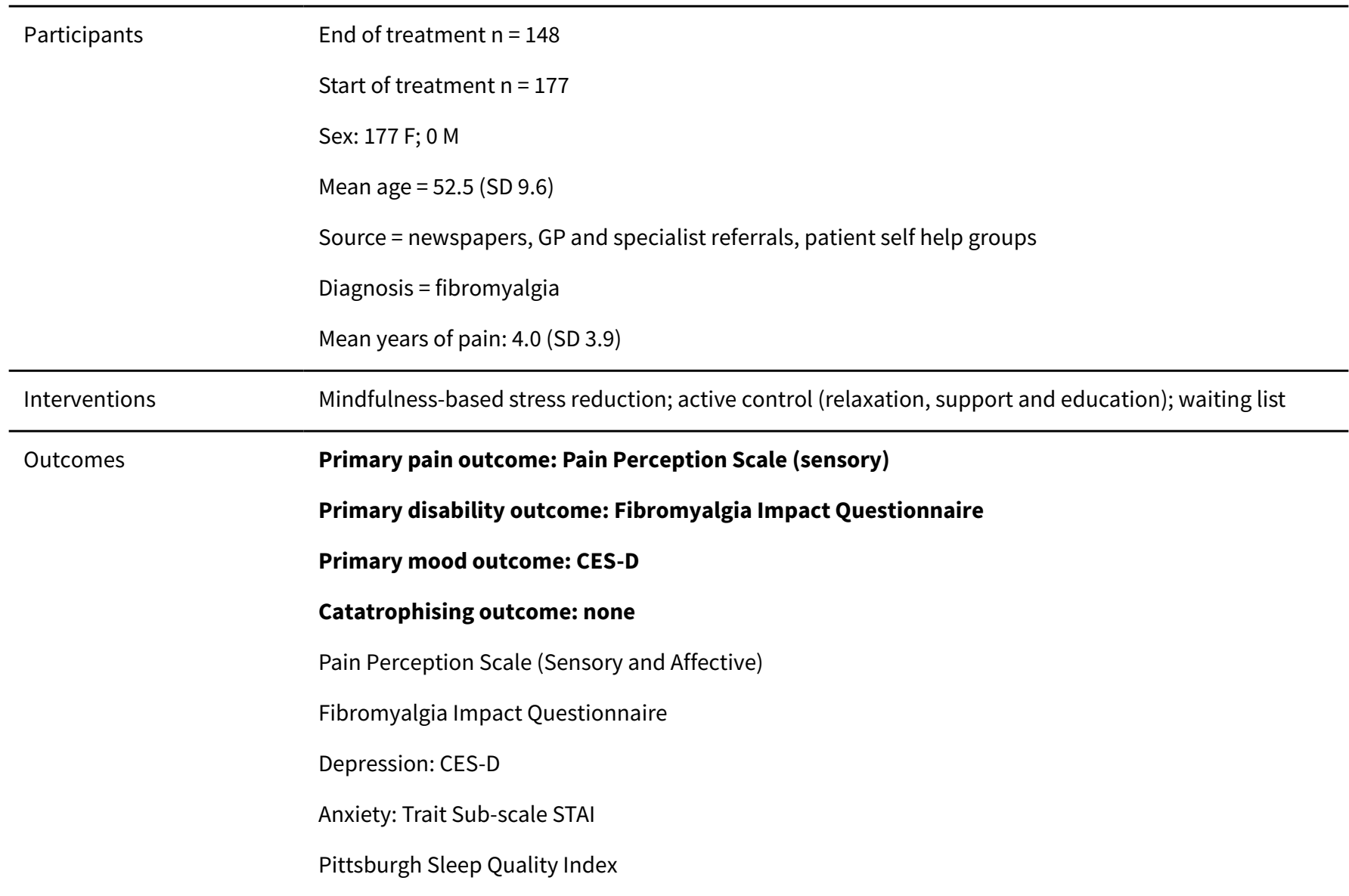


Schmidt 2011 (Continued)

Health-related Quality of Life

Freiburg Mindfulness Inventory

Physical symptoms: Giessen Complaint Questionnaire

Ongoing therapies, medical visits and medication

Medication diary

Goal-attainment scaling by interview

\begin{tabular}{ll}
\hline Notes & Active relaxation control versus waiting list; analyses $7.1,7.2,7.3$ \\
& 2011 update search \\
& Yates quality scale: total quality $=31 / 35$, design quality $=23 / 26$, treatment quality $=8 / 9$
\end{tabular}

\section{Risk of bias}

\section{Bias}

Random sequence genera- Low risk tion (selection bias)

Allocation concealment $\quad$ Low risk Patients and personnel blinded to treatment allocation
(selection bias)

Incomplete outcome data $\quad$ Unclear risk $\quad$ Attrition fully reported; no test for differences
(attrition bias)

"randomized in blocks by a computer algorithm"

\section{Authors' judgement Support for judgement}

All outcomes

\begin{tabular}{lll}
\hline $\begin{array}{l}\text { Selective reporting (re- } \\
\text { porting bias) }\end{array}$ & Low risk & Fully reported \\
\hline $\begin{array}{l}\text { Blinding of outcome as- } \\
\text { sessment (detection bias) } \\
\begin{array}{l}\text { All outcomes } \\
\hline\end{array}\end{array}$ & Low risk & Assessors blinded \\
\hline
\end{tabular}

Smeets 2006

\begin{tabular}{ll}
\hline Methods & RCT; 4 arms; assessed at pre-treatment, post-treatment, 1 year \\
\hline Participants & End of treatment $\mathrm{n}=212$ \\
& Start of treatment $\mathrm{n}=223$ \\
& Sex: $106 \mathrm{~F}, 117 \mathrm{M}$ \\
& Mean age $=41.6$ (SD 10.0) \\
& Source = pain or rehabilitation clinic \\
& Diagnosis = CLBP \\
& Mean years of pain = 4/6 \\
\hline Interventions & "Cognitive behavioural therapy + active physical treatment" \\
& "Cognitive behavioural therapy" \\
\hline
\end{tabular}


Smeets 2006 (Continued)

"active physical treatment"

"waiting list"

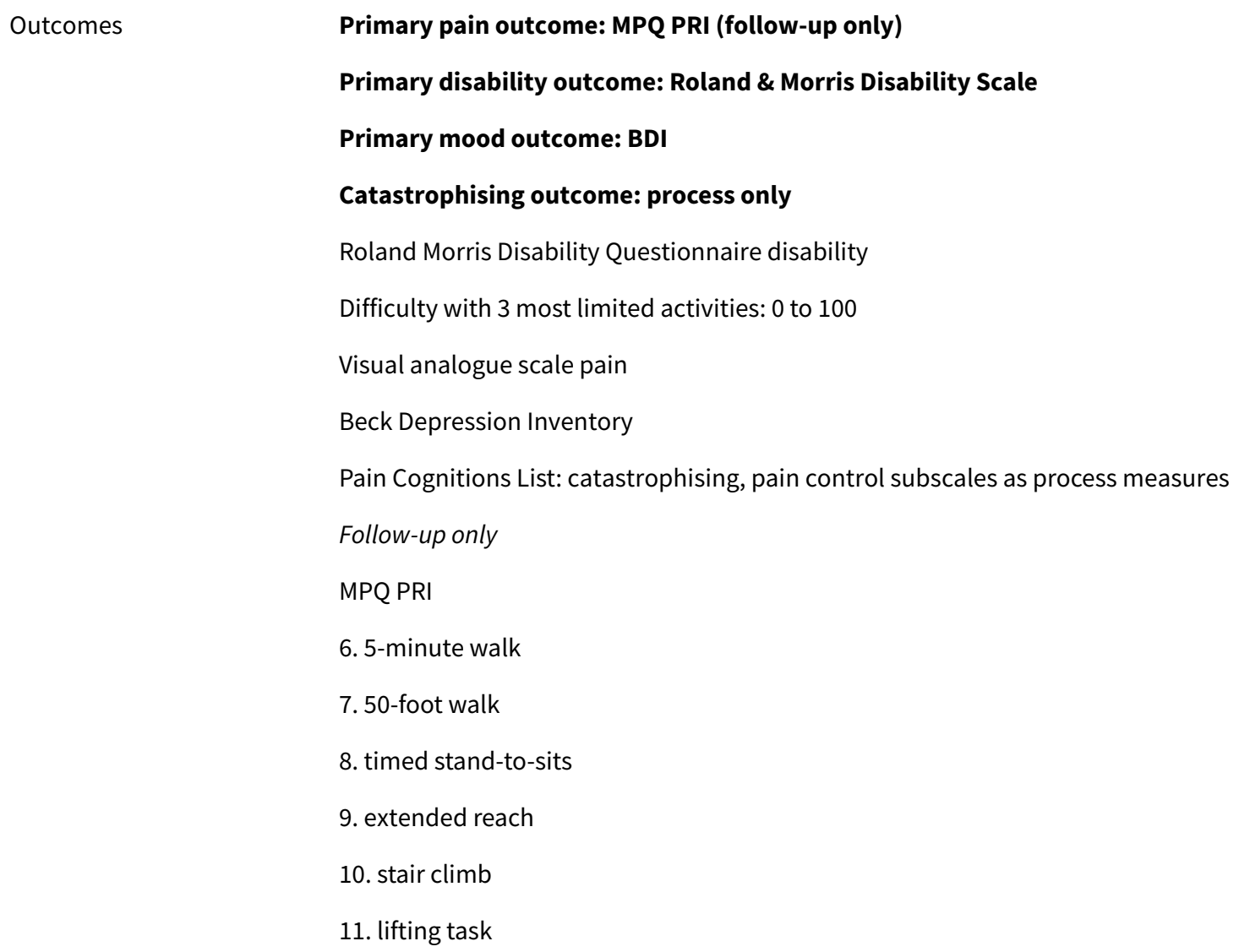

\section{Risk of bias}

\begin{tabular}{lll}
\hline Bias & Authors' judgement & Support for judgement \\
\hline $\begin{array}{l}\text { Random sequence genera- } \\
\text { tion (selection bias) }\end{array}$ & Low risk & Randomised in blocks by computer-generated algorithm \\
\hline $\begin{array}{l}\text { Allocation concealment } \\
\text { (selection bias) }\end{array}$ & Low risk & Generated by independent statistician; sealed envelopes \\
\hline $\begin{array}{l}\text { Incomplete outcome data } \\
\begin{array}{l}\text { (attrition bias) } \\
\text { All outcomes }\end{array}\end{array}$ & Unclear risk & Attrition fully reported; no test for differences \\
\hline $\begin{array}{l}\text { Selective reporting (re- } \\
\text { porting bias) }\end{array}$ & Low risk & Fully reported \\
\hline
\end{tabular}


Smeets 2006 (Continued)

Blinding of outcome as- Low risk Assessment by blinded research assistants sessment (detection bias)

All outcomes

\section{Strauss 1986}

\begin{tabular}{ll}
\hline Methods & RCT; 3 arms; assessed at pre-treatment, post-treatment, 6 months \\
\hline Participants & End of treatment $n=43$ \\
& Start of treatment $\mathrm{n}=57$ \\
& Sex: $46 \mathrm{~F}, 11 \mathrm{M}$ \\
& Mean age $=54.0$ (SD 13.0) \\
& Source = rheumatology clinic \\
& Diagnosis = rheumatoid arthritis \\
& Mean years of pain not given \\
\hline Interventions & "group psychotherapy" \\
"relaxation/assertion" & "no treatment" \\
\hline
\end{tabular}

Outcomes

Primary pain outcome: no data available

Primary disability outcome: no data available

Primary mood outcome: no data available

Catastrophising outcome: none

4 aggregate outcome measures:

Functional status, social adaptation, psychological adaptation, psychological symptoms

Measures contributing to these:

Arthritis Impact Measurement Scale (AIMS)

Short Form 36

Rathus Assertive Behavior Scale

Rosenberg Self-Esteem Scale

Hostility Inventory

Wright's Human Service Scale \& Handicap Problems Inventory

Notes data
Yates quality scale: total quality $=10 / 35$, design quality $=9 / 26$, treatment quality $=1 / 9$

\section{Risk of bias}


Strauss 1986 (Continued)

Random sequence genera- High risk "randomly assigned"
tion (selection bias)



$\begin{array}{lll}\begin{array}{l}\text { Allocation concealment } \\ \text { (selection bias) }\end{array} & \text { High risk reported }\end{array}$

\begin{tabular}{lll}
\hline $\begin{array}{l}\text { Incomplete outcome data } \\
\text { (attrition bias) }\end{array}$ & High risk & Attrition not reported \\
All outcomes & \\
\hline $\begin{array}{l}\text { Selective reporting (re- } \\
\text { porting bias) }\end{array}$ & High risk & Partially reported \\
\hline $\begin{array}{l}\text { Blinding of outcome as- } \\
\text { sessment (detection bias) } \\
\text { All outcomes }\end{array}$ & High risk & Not reported \\
\hline
\end{tabular}

\title{
Thieme 2003
}

\begin{tabular}{ll}
\hline Methods & RCT; 2 arms; assessed at pre-treatment, post-treatment, 6 months, 15 months \\
\hline Participants & End of treatment $n=61$ \\
& Start of treatment $n=83$ \\
& Sex: $61 \mathrm{~F}, 0 \mathrm{M}$ \\
& Mean age $=47.3$ (SD 8.3) \\
& Source = hospital for rheumatic disorders \\
& Diagnosis = fibromyalgia \\
Mean years of pain = 16.5 \\
\hline Interventions & "operant treatment" \\
\hline
\end{tabular}

\section{Outcomes}

\section{Primary pain outcome: MPI pain}

\section{Primary disability outcome: MPI interference}

Primary mood outcome: MPI affective distress

\author{
Catastrophising outcome: none \\ Diary pain intensity \\ Multidimensional Pain Inventory: pain \\ Multidimensional Pain Inventory: interference \\ Multidimensional Pain Inventory: life control \\ Multidimensional Pain Inventory: affective distress \\ Multidimensional Pain Inventory: social support \\ Multidimensional Pain Inventory: self efficacy
}


Thieme 2003 (Continued)

Multidimensional Pain Inventory: punishing responses, solicitous responses, distracting responses

Multidimensional Pain Inventory: total activities

Doctor visits (from medical records)

Hospital days (from medical records)

Sleep hours diary

Medication diary

Tubingen pain behaviour scale

Notes

BT versus TAU, post-treatment and follow-up: analyses 7.1, 7.2, 7.3, 8.1, 8.2, 8.3

Yates quality scale: total quality $=15 / 35$, design quality $=11 / 26$, treatment quality $=4 / 9$

\section{Risk of bias}

\begin{tabular}{lll}
\hline Bias & Authors' judgement & Support for judgement \\
\hline $\begin{array}{l}\text { Random sequence genera- } \\
\text { tion (selection bias) }\end{array}$ & High risk & "randomly assigned" \\
\hline $\begin{array}{l}\text { Allocation concealment } \\
\text { (selection bias) }\end{array}$ & High risk & Not reported \\
\hline $\begin{array}{l}\text { Incomplete outcome data } \\
\begin{array}{l}\text { (attrition bias) } \\
\text { All outcomes }\end{array}\end{array}$ & Unclear risk & Attrition reported; no test for differences \\
\hline $\begin{array}{l}\text { Selective reporting (re- } \\
\text { porting bias) }\end{array}$ & Low risk & Fully reported \\
\hline $\begin{array}{l}\text { Blinding of outcome as- } \\
\text { sessment (detection bias) } \\
\begin{array}{l}\text { All outcomes } \\
\hline\end{array}\end{array}$ & High risk & Not reported \\
\hline
\end{tabular}

Thorsell 2011

\begin{tabular}{ll}
\hline Methods & $\begin{array}{l}\text { RCT; } 2 \text { arms; self help acceptance and commitment therapy, self help applied relaxation; post-treat- } \\
\text { ment: } 6 \text {-month and 12-month follow-up }\end{array}$ \\
\hline Participants & End of treatment: $\mathrm{n}=64$ \\
& Start of treatment: $\mathrm{n}=98$ \\
& Sex: $63 \mathrm{~F} ; 35 \mathrm{M}$ \\
& Source $=$ pain clinic \\
& Diagnosis = mixed chronic pain \\
Mean age: 46.0 (SD 12.3) & Mean years of pain: not given (98\% more than 1 year) \\
\hline Interventions & Self help acceptance and commitment therapy; self help applied relaxation \\
\hline
\end{tabular}


Thorsell 2011 (Continued)

Outcomes

Primary pain outcome: pain intensity 0 to 10

Primary disability outcome: OMPQ 5 items

Primary mood outcome: Depression HADS

Catastrophising outcome: none

Pain intensity 0 to 10

Function: 5 items 0 to 10 from Orebro Musculoskeletal Pain Questionnaire (reverse direction)

Depression HADS

Anxiety HADS

Satisfaction With Life Scale

Chronic Pain Acceptance Questionnaire

Notes

ACT versus active control: analyses 1.1, 1.2, 1.3, 2.1, 2.2, 2.3

2011 update search

Yates quality scale: total quality $18 / 35$, design quality $13 / 26$, treatment quality $5 / 9$

\section{Risk of bias}

\begin{tabular}{|c|c|c|}
\hline Bias & Authors' judgement & Support for judgement \\
\hline $\begin{array}{l}\text { Random sequence genera- } \\
\text { tion (selection bias) }\end{array}$ & Unclear risk & "randomized by drawing pieces of paper with type of intervention" \\
\hline $\begin{array}{l}\text { Allocation concealment } \\
\text { (selection bias) }\end{array}$ & High risk & Not reported, but treatment credibility equal \\
\hline $\begin{array}{l}\text { Incomplete outcome data } \\
\text { (attrition bias) } \\
\text { All outcomes }\end{array}$ & Unclear risk & Attrition fully reported; no test for differences \\
\hline $\begin{array}{l}\text { Selective reporting (re- } \\
\text { porting bias) }\end{array}$ & Low risk & Fully reported \\
\hline $\begin{array}{l}\text { Blinding of outcome as- } \\
\text { sessment (detection bias) } \\
\text { All outcomes }\end{array}$ & High risk & Not reported \\
\hline
\end{tabular}

Turner 1988

\begin{tabular}{ll}
\hline Methods & RCT; 3 arms; assessed at pre-treatment, post-treatment, 6 months, 1 year \\
\hline Participants & End of treatment $n=53$ \\
& Start of treatment $n=81$ \\
& Sex: $30 \mathrm{~F}, 51 \mathrm{M}$ \\
& Mean age $=46.0$ (SD not given) \\
& Source = pain or rehabilitation clinic \\
\hline
\end{tabular}


Turner 1988 (Continued)

Diagnosis $=$ CLBP

Mean years of pain $=6.2$

\begin{tabular}{l}
\hline "CBT" \\
"operant behavior therapy" \\
"waiting list" \\
\hline
\end{tabular}

Outcomes Primary pain outcome: MPQ PRI

Primary disability outcome: SIP patient-rated

Primary mood outcome: none available

\section{Catastrophising outcome: CEQ}

Multidimensional Pain Questionnaire: Pain Response Index

Sickness Impact Profile: patient-rated

Sickness Impact Profile: spouse-rated

Pain behaviour (Keefe \& Block) observation

Pain Behavior Checklist patient-rated

Pain Behavior Checklist spouse-rated

Cognitive Errors Questionnaire

Notes
BT versus TAU, post-treatment (waiting list not followed up): analyses $3.1,3.2$
Yates quality scale: total quality $=23 / 35$, design quality $=15 / 26$, treatment quality $=8 / 9$

\section{Risk of bias}

\begin{tabular}{|c|c|c|}
\hline Bias & Authors' judgement & Support for judgement \\
\hline $\begin{array}{l}\text { Random sequence genera- } \\
\text { tion (selection bias) }\end{array}$ & High risk & "randomly assigned" \\
\hline $\begin{array}{l}\text { Allocation concealment } \\
\text { (selection bias) }\end{array}$ & High risk & Not reported \\
\hline $\begin{array}{l}\text { Incomplete outcome data } \\
\text { (attrition bias) } \\
\text { All outcomes }\end{array}$ & Unclear risk & Attrition fully reported; no test for differences \\
\hline $\begin{array}{l}\text { Selective reporting (re- } \\
\text { porting bias) }\end{array}$ & Low risk & Partially reported but full account of excluded measures \\
\hline $\begin{array}{l}\text { Blinding of outcome as- } \\
\text { sessment (detection bias) } \\
\text { All outcomes }\end{array}$ & High risk & Not reported \\
\hline
\end{tabular}


Turner 2006

\begin{tabular}{|c|c|}
\hline Methods & RCT.; 2 arms; assessed at pre-treatment, post-treatment, 6 months, 1 year \\
\hline \multirow[t]{7}{*}{ Participants } & End of treatment $n=142$ \\
\hline & Start of treatment $\mathrm{n}=158$ \\
\hline & Sex: 128 F, $30 \mathrm{M}$ \\
\hline & Mean age $=37.4($ SD 11.3) \\
\hline & Source = pain or rehabilitation clinic \\
\hline & Diagnosis = temporomandibular joint pain \\
\hline & Mean years of pain $=$ not given \\
\hline \multirow[t]{2}{*}{ Interventions } & "brief CBT: Pain Management Training" \\
\hline & "education/attention control: Self care control" \\
\hline \multirow[t]{13}{*}{ Outcomes } & Primary pain outcome: Graded Chronic Pain Scale: Pain Intensity \\
\hline & Primary disability outcome: none available \\
\hline & Primary mood outcome: BDI depression \\
\hline & Catastrophising outcome: PCS \\
\hline & Graded Chronic Pain Scale: Activity Interference \\
\hline & Graded Chronic Pain Scale: Pain Intensity \\
\hline & Beck Depression Inventory (BDI) \\
\hline & Mandibular Function Impairment Questionnaire (MFIQ) \\
\hline & Survey of Pain Attitudes (SOPA) \\
\hline & TMD self efficacy scale \\
\hline & CSQ catastrophising subscale \\
\hline & Pain Catastrophizing Scale rumination subscale \\
\hline & Chronic Pain Coping Inventory ( $\mathrm{CPCI})$ task persistence, coping self statements, relaxation, rest \\
\hline
\end{tabular}

Notes

CBT versus active, post-treatment and follow-up: analyses 1.1, 1.3, 2.1, 2.3

Yates quality scale: total quality $=27 / 35$, design quality $=22 / 26$, treatment quality $=5 / 9$

\section{Risk of bias}

\begin{tabular}{lll}
\hline Bias & Authors' judgement & Support for judgement \\
\hline $\begin{array}{l}\text { Random sequence genera- } \\
\text { tion (selection bias) }\end{array}$ & Low risk & Computer-generated by biostatistician \\
\hline $\begin{array}{l}\text { Allocation concealment } \\
\text { (selection bias) }\end{array}$ & Low risk & $\begin{array}{l}\text { Sealed envelopes; independent personnel; treatment credibility unequal so } \\
\text { used as covariate }\end{array}$ \\
\hline $\begin{array}{l}\text { Incomplete outcome data } \\
\text { (attrition bias) } \\
\text { All outcomes }\end{array}$ & Unclear risk & Attrition fully reported; no test for differences \\
\hline \hline
\end{tabular}


Turner 2006 (Continued)

\begin{tabular}{lll}
$\begin{array}{l}\text { Selective reporting (re- } \\
\text { porting bias) }\end{array}$ & Low risk & Fully reported \\
\hline $\begin{array}{l}\text { Blinding of outcome as- } \\
\text { sessment (detection bias) } \\
\text { All outcomes }\end{array}$ & High risk & Not reported \\
\hline
\end{tabular}

Van Koulil 2010

\begin{tabular}{ll}
\hline Methods & RCT; 2 arms; CBT: WLC; post-treatment: 6-month follow-up \\
\hline Participants & End of treatment: $n=152$ \\
& Start of treatment: $\mathrm{n}=158$ \\
& Sex: $148 \mathrm{~F}, 10 \mathrm{M}$ \\
& Mean age: 40.8 (SD 10.5) \\
& Mean years of pain: not given (<5 years since diagnosis) \\
& Source = rheumatology clinics \\
Diagnosis = fibromyalgia
\end{tabular}

Primary pain outcome: Pain IRGL
Primary disability outcome: Mobility IRGL
Primary mood outcome: Negative mood IR
Catastrophising outcome: none
Pain: 6 items of IRGL
Disability: 7 mobility items of IRGL (reversed)
Impact: Fibromyalgia Impact Questionnaire
Negative mood: 6 items of IRGL
Anxiety: 10 items of IRGL

Notes

CBT versus WLC: analyses 3.1, 3.2, 3.3, 4.1, 4.2, 4.3

2011 update search

Yates quality scale: total quality $24 / 35$, design quality $15 / 26$, treatment quality $9 / 9$

\section{Risk of bias}

\begin{tabular}{lll}
\hline Bias & Authors' judgement & Support for judgement \\
\hline $\begin{array}{l}\text { Random sequence genera- } \\
\text { tion (selection bias) }\end{array}$ & High risk & "randomized in clusters" \\
\hline
\end{tabular}


Van Koulil 2010 (Continued)

\begin{tabular}{l}
$\begin{array}{l}\text { Allocation concealment } \\
\text { (selection bias) }\end{array}$ High risk Not reported \\
\hline
\end{tabular}

Incomplete outcome data Unclear risk

Attrition reported; 2 differences between dropouts and completers

(attrition bias)

All outcomes

\begin{tabular}{lll}
\hline $\begin{array}{l}\text { Selective reporting (re- } \\
\text { porting bias) }\end{array}$ & Low risk & Fully reported \\
\end{tabular}

Blinding of outcome as- High risk Not reported

sessment (detection bias)

All outcomes

\section{Vlaeyen 1996}

\begin{tabular}{ll}
\hline Methods & RCT; 3 arms; assessed at pre-treatment, post-treatment, 6 months, 1 year \\
\hline Participants & End of treatment $n=122$ \\
& Start of treatment $n=131$ \\
& Sex: $110 \mathrm{~F}, 15 \mathrm{M}$ \\
& Mean age $=44.0$ (SD 9.4) \\
& Source = pain or rehabilitation clinic \\
& Diagnosis = fibromyalgia \\
Mean years of pain = 10.2 \\
\hline "cognitive + group discussion" \\
"education + group discussion" \\
"waiting list"
\end{tabular}

Outcomes

Primary pain outcome: pain intensity score

Primary disability outcome: none available

Primary mood outcome: BDI depression

Catastrophising outcome: none

Composite scores from factor analysis:

Pain intensity, pain coping, pain control, relaxation, catastrophising, pain behaviour, activi-

ty

Measures contributing to factors:

Multidimensional Pain Questionnaire: Pain Response Index

Coping Strategies Questionnaire (CSQ)

Beck Depression Inventory (BDI) (none available)

Fear Survey Schedule 
Vlaeyen 1996 (Continued)

Arthritis knowledge

Maudsley Obsessive Compulsive Inventory

Pain behaviour scale

Multidimensional Pain Locus of Control Scale (MPCL)

Walking distance, walking time, cycling time

Notes $\quad$ CBT versus active, post-treatment: analyses 1.1, 1.3

Yates quality scale: total quality $=20 / 35$, design quality $=16 / 26$, treatment quality $=4 / 9$

\section{Risk of bias}

\begin{tabular}{lll}
\hline Bias & Authors' judgement & Support for judgement \\
\hline $\begin{array}{l}\text { Random sequence genera- } \\
\text { tion (selection bias) }\end{array}$ & High risk & "randomly assigned" \\
\hline $\begin{array}{l}\text { Allocation concealment } \\
\text { (selection bias) }\end{array}$ & High risk & Not reported \\
\hline $\begin{array}{l}\text { Incomplete outcome data } \\
\text { (attrition bias) } \\
\text { All outcomes }\end{array}$ & Low risk & Attrition reported \\
\hline $\begin{array}{l}\text { Selective reporting (re- } \\
\text { porting bias) }\end{array}$ & Low risk & Fully reported \\
\hline $\begin{array}{l}\text { Blinding of outcome as- } \\
\text { sessment (detection bias) } \\
\begin{array}{l}\text { All outcomes } \\
\hline\end{array}\end{array}$ & High risk & Not reported \\
\hline
\end{tabular}

\section{Wetherell 2011}

\begin{tabular}{|c|c|}
\hline Methods & RCT; 2 arms; acceptance and commitment therapy, CBT; post-treatment and 6 month follow-up \\
\hline \multirow[t]{7}{*}{ Participants } & End of treatment: $n=99$ \\
\hline & Start of treatment: $\mathrm{n}=114$ \\
\hline & Sex: 58 F; 56 M \\
\hline & Mean age: 54.9 (SD 12.5) \\
\hline & Mean years of pain: 15 (SD 35.5) \\
\hline & $\begin{array}{l}\text { Source = primary care }(40 \%) \text {; adverts and newspaper article }(40 \%) \text {; pain support groups }(10 \%) \text {; various } \\
(10 \%)\end{array}$ \\
\hline & Diagnosis = mixed chronic pain \\
\hline Interventions & $A C T$ versus $C B T$ \\
\hline \multirow[t]{2}{*}{ Outcomes } & Primary pain outcome: BPI pain severity \\
\hline & Primary disability outcome: BPI interference \\
\hline
\end{tabular}




\title{
Primary mood outcome: BDI
}

\section{Catastrophising outcome: none}

Pain severity: BPI Sub-scale

Disability: BPI Interference Sub-scale (primary outcome)

Disability: MPI General Activity Sub-scale

Depression: BDI-II

Anxiety: PASS

Quality of life: SF-12 physical and mental subscores

Treatment Satisfaction Questionnaire

2011 update search.

Yates quality scale: total quality $=32 / 35$, design quality $=24 / 26$, treatment quality $=8 / 9$

\section{Risk of bias}

\begin{tabular}{lll}
\hline Bias & Authors' judgement & Support for judgement \\
\hline $\begin{array}{l}\text { Random sequence genera- } \\
\text { tion (selection bias) }\end{array}$ & Low risk & Group randomisation generated by computer \\
\hline $\begin{array}{l}\text { Allocation concealment } \\
\text { (selection bias) }\end{array}$ & Low risk & $\begin{array}{l}\text { Staff member who accessed randomisation code had no contact with partici- } \\
\text { pants }\end{array}$ \\
\hline $\begin{array}{l}\text { Incomplete outcome data } \\
\text { (attrition bias) } \\
\text { All outcomes }\end{array}$ & Unclear risk & Attrition fully reported; several differences between dropouts and completers \\
\hline $\begin{array}{l}\text { Selective reporting (re- } \\
\text { porting bias) }\end{array}$ & Low risk & Fully reported \\
\hline $\begin{array}{l}\text { Blinding of outcome as- } \\
\text { sessment (detection bias) } \\
\begin{array}{l}\text { All outcomes } \\
\hline\end{array}\end{array}$ & Low risk & Assessment staff blind to treatment condition \\
\hline
\end{tabular}

Williams 1996

Methods $\quad$ RCT; 3 arms; assessed at pre-treatment, post-treatment, 6 months, 1 year

Participants

\author{
End of treatment $\mathrm{n}=99$ \\ Start of treatment $\mathrm{n}=121$ \\ Sex: 68 F, 53 M \\ Mean age $=50.0($ SD 11.5) \\ Source $=$ pain clinic \\ Diagnosis $=$ mixed chronic pain, low back commonest
}


Williams 1996 (Continued)

Mean years of pain $=7.8$

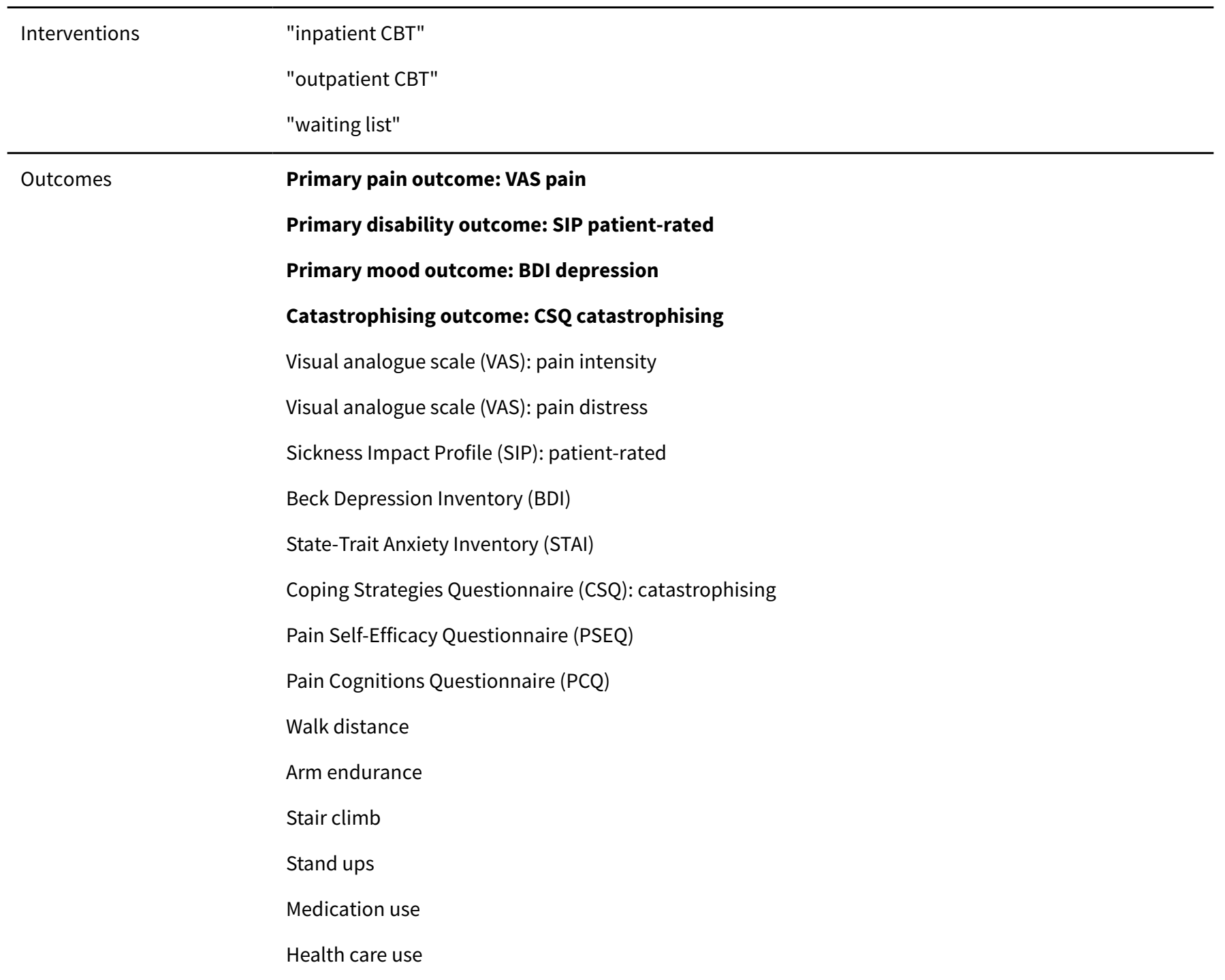

Notes CBT versus TAU, post-treatment (waiting list not followed up): analyses 3.1, 3.2, 3.3

Yates quality scale: total quality $=22 / 35$, design quality $=15 / 26$, treatment quality $=7 / 9$

\section{Risk of bias}

\begin{tabular}{lll}
\hline Bias & Authors' judgement & Support for judgement \\
\hline $\begin{array}{l}\text { Random sequence genera- } \\
\text { tion (selection bias) }\end{array}$ & Unclear risk & "Randomly assigned by throw of a die" \\
\hline $\begin{array}{l}\text { Allocation concealment } \\
\text { (selection bias) }\end{array}$ & High risk & Not reported \\
\hline $\begin{array}{l}\text { Incomplete outcome data } \\
\text { (attrition bias) } \\
\text { All outcomes }\end{array}$ & Low risk & Attrition reported \\
\hline
\end{tabular}


Williams 1996 (Continued)

Selective reporting (re- High risk Partially reported
porting bias)

Blinding of outcome as-

\title{
Zautra 2008
}

\begin{tabular}{ll}
\hline Methods & RCT; 3 arms; Assessed at pre-treatment, post-treatment, 6 months follow-up \\
\hline Participants & Start of treatment N = 142 \\
& End of treatment N $=137$ \\
& $46 \mathrm{M}, 97 \mathrm{~F}$ \\
& Mean age 62.1 men, 50.6 women \\
& Diagnosis = rheumatoid arthritis \\
& Mean years of rheumatoid arthritis 15.4 years men, 11.6 years women \\
\hline Interventions & "cognitive behavioral therapy for pain" \\
"mindfulness meditation and emotion regulation therapy" & "education-only group"
\end{tabular}

Outcomes

Primary pain outcome: pain diary 0 to 100

Primary disability outcome: none

Primary mood outcome: PANAS negative affect

Catastrophising outcome: CSQ catastrophising subscale rescored

Pain once-daily diary 0 to 100

Positive and Negative Affect Schedule (PANAS): provides positive affect and negative affect scores

Depressive symptoms: sum of 6 items

Pain coping efficacy ( 2 items, 1 to 5 )

CSQ catastrophising subscale

Pain control 1 to 10

Disease Activity Score from examination of 28 joints by rheumatologist

Interleukin IL-6

Notes

\author{
December 2009 search \\ Data obtained from author
}

Used CBT for pain and education control group: 1.1, 1.3, 1.4, 2.1, 2.3, 2.4

Yates quality scale: total quality $=27 / 35$, design quality $=19 / 26$, treatment quality $=8 / 9$ 
Zautra 2008 (Continued)

Risk of bias

\begin{tabular}{lll}
\hline Bias & Authors' judgement & Support for judgement \\
\hline $\begin{array}{l}\text { Random sequence genera- } \\
\text { tion (selection bias) }\end{array}$ & Low risk & Random numbers table \\
\hline $\begin{array}{l}\text { Allocation concealment } \\
\text { (selection bias) }\end{array}$ & High risk & Not reported; treatment credibility measured but at end of treatment \\
\hline $\begin{array}{l}\text { Incomplete outcome data } \\
\text { (attrition bias) } \\
\text { All outcomes }\end{array}$ & Unclear risk & Attrition fully reported; no test for differences \\
\hline $\begin{array}{l}\text { Selective reporting (re- } \\
\text { porting bias) }\end{array}$ & Low risk & Fully reported \\
\hline $\begin{array}{l}\text { Blinding of outcome as- } \\
\text { sessment (detection bias) } \\
\begin{array}{l}\text { All outcomes } \\
\hline\end{array}\end{array}$ & Low risk & Assessment by staff not involved in treatment \\
\hline
\end{tabular}

AIMS: Arthritis Impact Measurement Scale; BDI: Beck Depression Inventory; BT: behaviour therapy; CBT: cognitive behavioural therapy; CEQ: Cognitive Errors Questionnaire; CES-D: Center for Epidemiologic Studies Depression Scale; CLBP: chronic low back pain; CSQ: Coping Strategies Questionnaire; DASS: Depression, Anxiety \& Stress Scale; EMG: electromyograph; FESV: Pain-Related Distress Questionnaire; FIQ: Fibromyalgia Impact Questionnaire; GA: graded activity; HADS: Hospital Anxiety and Depression Scale; HSCL: Hopkins Checklist; IRGL: Invloed van Reuma op Gezondheid en Leefwijze; MPQ PRI: Melzack Pain Questionnaire Pain Response Index; NRS: numerical rating scale; OMPQ: Orebro Musculoskeletal Pain Questionnaire; PANAS: Positive and Negative Affect Schedule; PCCL: Pain Coping and Cognition List; PCS: Pain Catastrophizing Scale; PDI: Pain Disability Index; PRSS: Pain-Related Self-Statements; PT: physical treatment; RAI: Rheumatoid Arthritis Index; RCT: randomised controlled trial; SD: standard deviation; SIP: Sickness Impact Profile; SLE: systemic lupus erythematosus; SOPA: Survey of Pain Attitudes; TAU: treatment as usual; TSK: Tampa Scale for Kinesiophobia; VAS: visual analogue scale; WHO: World Health Organization; WHYMPI: West Haven Yale Multidimensional Pain Inventory; WLC: waiting list control.

Characteristics of excluded studies [ordered by study ID]

\begin{tabular}{ll}
\hline Study & Reason for exclusion \\
\hline Abbott 2010 & Insufficient psychotherapeutic content \\
\hline Abrahamsen 2008 & Hypnosis study \\
\hline Appelbaum 1988 & Inadequate n: the number of patients in any treatment arm was less than 10 \\
\hline Asenlof 2005 & Not chronic pain \\
\hline Astin 2003 & Insufficient psychotherapeutic content \\
\hline Babu 2007 & $\mathrm{~N}<20$ \\
\hline Becker 2000 & $\begin{array}{l}\text { Insufficient psychotherapeutic content (participants could opt out of psychology and 71\% } \\
\text { did) }\end{array}$ \\
\hline Bendix 1997 & Insufficient psychotherapeutic content \\
\hline Bradley 1987 & $\mathrm{~N}<20$ \\
\hline
\end{tabular}




\begin{tabular}{|c|c|}
\hline Study & Reason for exclusion \\
\hline Broderick 2004 & Insufficient psychotherapeutic content \\
\hline Brox 2003 & Insufficient psychotherapeutic content \\
\hline Buhrman 2004 & Internet trial \\
\hline Carson 2005 & Insufficient psychotherapeutic content \\
\hline Carson 2010 & Insufficient psychotherapeutic content \\
\hline Castel 2009 & $\mathrm{n}<10$ \\
\hline Christiansen 2010 & Not all had chronic pain \\
\hline Cook 1998 & $\mathrm{~N}<20$ \\
\hline Corrado 2003 & No primary psychological treatment for pain or non-psychological comparator \\
\hline Currie 2000 & No primary psychological treatment for pain or non-psychological comparator \\
\hline Dahl 2004 & $\mathrm{~N}<10$ \\
\hline Dalton 2004 & Not chronic pain \\
\hline de Sousa 2009 & Insufficient psychotherapeutic content \\
\hline Dufour 2010 & Insufficient psychotherapeutic content \\
\hline Dworkin 1994 & Intervention pre-dental procedure: no outcome of psychology intervention available \\
\hline Dworkin 2002a & Insufficient psychotherapeutic content \\
\hline Dworkin 2002b & Insufficient psychotherapeutic content \\
\hline Edinger 2005 & No primary psychological treatment for pain or non-psychological comparator \\
\hline Ersek 2003 & $\mathrm{~N}<20$ \\
\hline Esmer 2010 & Insufficient psychotherapeutic content \\
\hline Evans 2003 & Not chronic pain \\
\hline Fairbank 2005 & Cross-over trial and data on outcome collected after cross-over \\
\hline Ferrari 2006 & Not clearly randomised \\
\hline Flor 1993 & $\mathrm{~N}<20$ \\
\hline Fors 2000 & Insufficient psychotherapeutic content \\
\hline Freeman 2002 & Insufficient psychotherapeutic content \\
\hline Garcia-Campayo 2009 & Trial plan not trial \\
\hline George 2008 & Insufficient psychotherapeutic content \\
\hline
\end{tabular}




\begin{tabular}{|c|c|}
\hline Study & Reason for exclusion \\
\hline Glombiewski 2010a & Not a treatment trial \\
\hline Haugstad 2006 & Insufficient psychotherapeutic content \\
\hline Jensen 2009 & Hypnosis study \\
\hline Johansson 1998 & $\mathrm{~N}<20$ \\
\hline Kapitza 2010 & Insufficient psychotherapeutic content \\
\hline Keefe 2004 & $\mathrm{~N}<20$ \\
\hline Keller 2004 & Insufficient psychotherapeutic content \\
\hline Kerns 1986 & $\mathrm{~N}<10$ \\
\hline Kroenke 2009 & Insufficient psychotherapeutic content \\
\hline Lamb 2010 & Insufficient psychotherapeutic content \\
\hline Lambeek 2009 & Insufficient psychotherapeutic content \\
\hline Li 2006 & Insufficient psychotherapeutic content \\
\hline Liedl 2011 & $\mathrm{~N}<20$ \\
\hline Linton 1984 & $\mathrm{~N}<10$ \\
\hline Linton 1985 & $\mathrm{~N}<10$ \\
\hline Linton 2001 & Not chronic pain \\
\hline Linton 2005 & Not chronic pain \\
\hline Linton 2008 & $\mathrm{~N}<20$ \\
\hline Lorig 2008 & Internet trial \\
\hline Machado 2007 & Insufficient psychotherapeutic content (counselling) \\
\hline Marhold 2001 & $\mathrm{~N}<20$ \\
\hline Menzel 2006 & $\mathrm{~N}<10$ \\
\hline Moffett 2005 & Insufficient psychotherapeutic content \\
\hline Moore 1985 & $\mathrm{~N}<20$ \\
\hline Moore 2000 & Not chronic pain \\
\hline Morone 2008 & Insufficient psychotherapeutic content \\
\hline Morone 2009 & Insufficient psychotherapeutic content \\
\hline Newton-John 1995 & $\mathrm{~N}<20$ \\
\hline
\end{tabular}




\begin{tabular}{|c|c|}
\hline Study & Reason for exclusion \\
\hline Nicholas 1991 & $\mathrm{~N}<10$ \\
\hline Nicholas 1992 & $\mathrm{~N}<10$ \\
\hline O'Leary 1988 & $\mathrm{~N}<20$ \\
\hline Parker 2003 & Intervention for depression not pain \\
\hline Peters 1990 & $\mathrm{~N}<10$ \\
\hline Radojevic 1992 & $\mathrm{~N}<20$ \\
\hline Redondo 2004 & $\mathrm{~N}<20$ \\
\hline Rendant 2011 & Insufficient psychotherapeutic content \\
\hline Sahin 2011 & Insufficient psychotherapeutic content \\
\hline Schulze 2008 & Not random allocation \\
\hline Schweikert 2006 & Insufficient psychotherapeutic content \\
\hline Sharpe 2001 & Not chronic pain \\
\hline Smeets 2009 & Study of predictors not outcomes of intervention \\
\hline Soderlund 2001 & Insufficient psychotherapeutic content \\
\hline Spence 1989 & $\mathrm{~N}<20$ \\
\hline Spence 1995 & $\mathrm{~N}<20$ \\
\hline Strong 1998 & Insufficient psychotherapeutic content \\
\hline Turner 1982 & $\mathrm{~N}<10$ \\
\hline Turner 1990 & $\mathrm{~N}<20$ \\
\hline Turner 1993 & $\mathrm{~N}<20$ \\
\hline Turner 2011 & Insufficient psychotherapeutic content \\
\hline Turner-Stokes 2003 & Equivalence trial \\
\hline Van den Hout 2003 & Not chronic pain \\
\hline Van Lankveld 2004 & No primary psychological treatment for pain or non-psychological comparator \\
\hline Vlaeyen 1995 & $\mathrm{~N}<20$ \\
\hline Wicksell 2008 & $\mathrm{~N}<20$ \\
\hline Wong 2011 & Insufficient psychotherapeutic content \\
\hline Woods 2008 & $\mathrm{~N}<20$ \\
\hline
\end{tabular}


Characteristics of studies awaiting assessment [ordered by study ID]

Bergdahl 1995

\begin{tabular}{ll}
\hline Methods & RCT; 2 arms; CT and "attention control" equivalent to treatment as usual \\
\hline Participants & End of treatment: $n=30$ \\
& Start of treatment: $n=30$ \\
& Sex: $24 \mathrm{~F} ; 6 \mathrm{M}$ \\
& Mean age: 46 (range 38 to 57$)$ \\
& Mean years of pain: not given \\
& Source: not given \\
& Diagnosis: resistant burning mouth syndrome \\
\hline Interventions & Cognitive therapy; regular monitoring \\
\hline Outcomes & Pain on 1 to 7 scale \\
\hline Notes & Not identified by electronic searches but from references of another review \\
\hline
\end{tabular}

DATA AND ANALYSES

Comparison 1. Cognitive behavioural vs active control post-treatment

\begin{tabular}{lllll}
\hline $\begin{array}{l}\text { Outcome or sub- } \\
\text { group title }\end{array}$ & $\begin{array}{l}\text { No. of } \\
\text { studies }\end{array}$ & $\begin{array}{l}\text { No. of } \\
\text { partici- } \\
\text { pants }\end{array}$ & Statistical method & Effect size \\
\hline 1 Pain & 13 & 1258 & Std. Mean Difference (IV, Random, 95\% CI) & $-0.10[-0.24,0.04]$ \\
\hline 2 Disability & 12 & 1130 & Std. Mean Difference (IV, Random, 95\% Cl) & $-0.19[-0.33,-0.05]$ \\
\hline 3 Mood & 13 & 1256 & Std. Mean Difference (IV, Random, 95\% CI) & $-0.05[-0.19,0.09]$ \\
\hline 4 Catastrophising & 6 & 735 & Std. Mean Difference (IV, Random, 95\% Cl) & $-0.18[-0.36,0.00]$ \\
\hline
\end{tabular}

Analysis 1.1. Comparison 1 Cognitive behavioural vs active control post-treatment, Outcome 1 Pain.

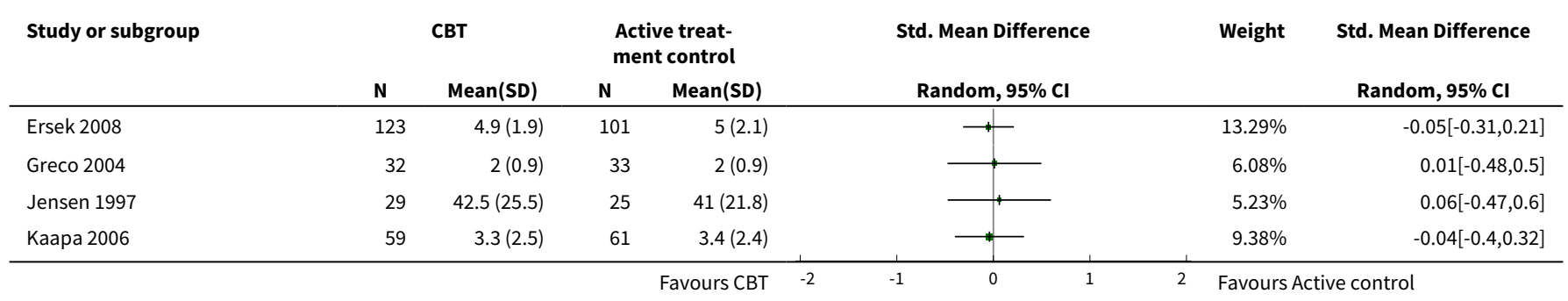




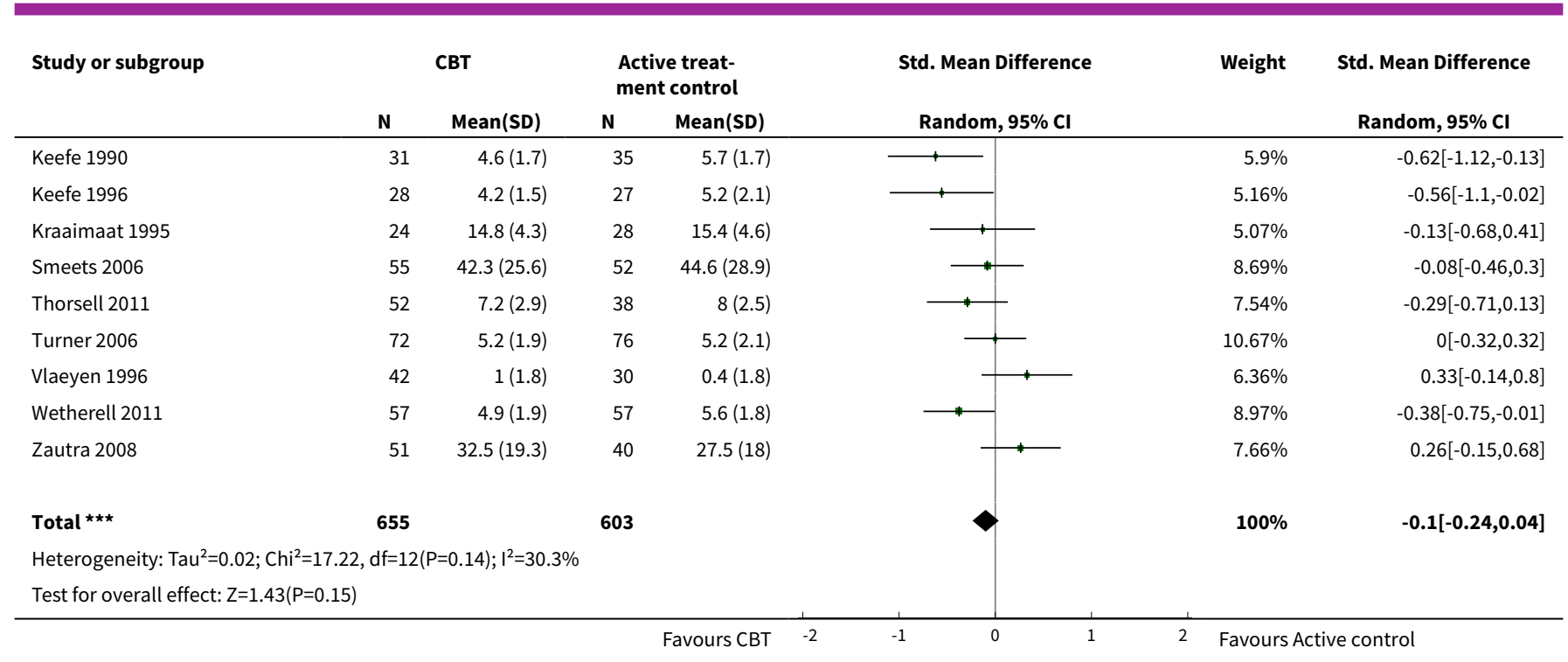

Analysis 1.2. Comparison 1 Cognitive behavioural vs active control post-treatment, Outcome 2 Disability.

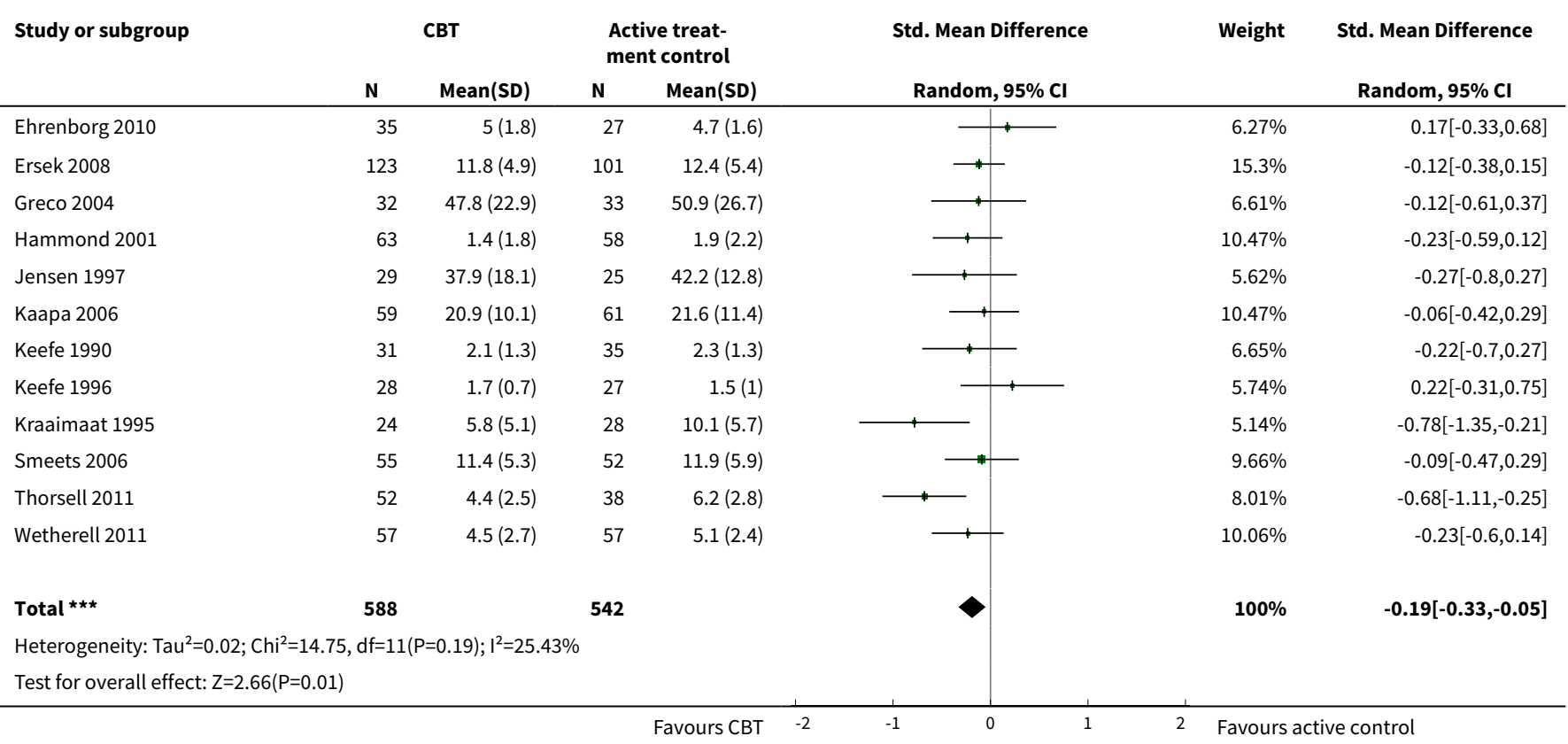

Analysis 1.3. Comparison 1 Cognitive behavioural vs active control post-treatment, Outcome 3 Mood.

\begin{tabular}{|c|c|c|c|c|c|c|c|}
\hline \multirow[t]{2}{*}{ Study or subgroup } & \multicolumn{2}{|c|}{ CBT } & \multicolumn{2}{|c|}{$\begin{array}{l}\text { Active treat- } \\
\text { ment control }\end{array}$} & \multirow{2}{*}{$\begin{array}{l}\text { Std. Mean Difference } \\
\text { Random, } 95 \% \mathrm{Cl}\end{array}$} & \multirow[t]{2}{*}{ Weight } & \multirow{2}{*}{$\begin{array}{l}\text { Std. Mean Difference } \\
\text { Random, } 95 \% \mathrm{Cl}\end{array}$} \\
\hline & $\mathbf{N}$ & Mean(SD) & $\mathbf{N}$ & Mean(SD) & & & \\
\hline Ersek 2008 & 123 & $11.1(2.9)$ & 101 & $10.9(3.3)$ & $\longrightarrow$ & $12.76 \%$ & $0.06[-0.2,0.33]$ \\
\hline Greco 2004 & 32 & $14.9(10.1)$ & 33 & $16.5(11.5)$ & $\longrightarrow$ & $6.19 \%$ & $-0.15[-0.64,0.34]$ \\
\hline Jensen 1997 & 29 & $9(6.7)$ & 25 & $9.9(6.8)$ & 1 & $5.37 \%$ & $-0.13[-0.67,0.4]$ \\
\hline
\end{tabular}




\begin{tabular}{|c|c|c|c|c|c|c|c|}
\hline \multirow[t]{2}{*}{ Study or subgroup } & \multicolumn{2}{|c|}{ CBT } & \multicolumn{2}{|c|}{$\begin{array}{l}\text { Active treat- } \\
\text { ment control }\end{array}$} & \multirow{2}{*}{$\begin{array}{l}\text { Std. Mean Difference } \\
\text { Random, } 95 \% \mathrm{Cl} \\
\end{array}$} & \multirow[t]{2}{*}{ Weight } & \multirow{2}{*}{$\begin{array}{l}\text { Std. Mean Difference } \\
\text { Random, } 95 \% \mathrm{Cl} \\
\end{array}$} \\
\hline & $\mathbf{N}$ & Mean(SD) & $\mathbf{N}$ & Mean(SD) & & & \\
\hline Kaapa 2006 & 59 & $5.5(5.5)$ & 61 & $5.7(5.2)$ & $\because$ & $9.3 \%$ & $-0.04[-0.4,0.32]$ \\
\hline Keefe 1990 & 31 & $2.6(1.7)$ & 35 & $2.1(0.9)$ & . & $6.17 \%$ & $0.37[-0.11,0.86]$ \\
\hline Keefe 1996 & 28 & $1.7(1)$ & 27 & $2.5(1.6)$ & 一 & $5.29 \%$ & $-0.59[-1.13,-0.05]$ \\
\hline Kraaimaat 1995 & 24 & $3.1(3.5)$ & 28 & $2.2(2.9)$ & 1 & $5.18 \%$ & $0.28[-0.27,0.83]$ \\
\hline Smeets 2006 & 54 & $9.1(6.5)$ & 52 & $7.7(6.6)$ & + & $8.6 \%$ & $0.21[-0.17,0.59]$ \\
\hline Thorsell 2011 & 52 & $6.6(5)$ & 38 & $8.2(5)$ & - & $7.58 \%$ & $-0.32[-0.74,0.1]$ \\
\hline Turner 2006 & 72 & $8.8(9.3)$ & 76 & $11(10.6)$ & . & $10.43 \%$ & $-0.22[-0.54,0.1]$ \\
\hline Vlaeyen 1996 & 42 & $13.4(5.8)$ & 30 & $11.9(5.8)$ & $\rightarrow$ & $6.5 \%$ & $0.26[-0.21,0.73]$ \\
\hline Wetherell 2011 & 57 & $13.2(11.1)$ & 57 & $17.8(12.2)$ & 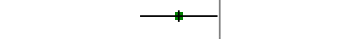 & $8.91 \%$ & $-0.39[-0.76,-0.02]$ \\
\hline Zautra 2008 & 50 & $1.3(0.3)$ & 40 & $1.3(0.3)$ & - & $7.71 \%$ & $0[-0.42,0.42]$ \\
\hline Total $\star \star \star$ & 653 & & 603 & & & $100 \%$ & $-0.05[-0.19,0.09]$ \\
\hline \multicolumn{8}{|c|}{ Heterogeneity: $\operatorname{Tau}^{2}=0.02 ; \mathrm{Chi}^{2}=18.47, \mathrm{df}=12(\mathrm{P}=0.1) ; \mathrm{I}^{2}=35.03 \%$} \\
\hline \multicolumn{8}{|c|}{ Test for overall effect: $Z=0.72(P=0.47)$} \\
\hline
\end{tabular}

\section{Analysis 1.4. Comparison 1 Cognitive behavioural vs active control post-treatment, Outcome 4 Catastrophising.}

\begin{tabular}{|c|c|c|c|c|c|c|c|}
\hline \multirow[t]{2}{*}{ Study or subgroup } & \multicolumn{2}{|c|}{ Treatment } & \multicolumn{2}{|c|}{ Control } & \multirow{2}{*}{$\begin{array}{c}\text { Std. Mean Difference } \\
\text { Random, } 95 \% \mathrm{Cl}\end{array}$} & \multirow[t]{2}{*}{ Weight } & \multirow{2}{*}{$\begin{array}{c}\text { Std. Mean Difference } \\
\text { Random, } 95 \% \mathrm{Cl}\end{array}$} \\
\hline & $\mathbf{N}$ & Mean(SD) & $\mathbf{N}$ & $\operatorname{Mean}(S D)$ & & & \\
\hline Ersek 2008 & 133 & $1(1.1)$ & 123 & $1.2(1.2)$ & 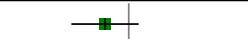 & $27.5 \%$ & $-0.17[-0.42,0.07]$ \\
\hline Greco 2004 & 32 & $5.3(3.1)$ & 33 & $6.1(3.5)$ & \begin{tabular}{l|l}
1 & \\
\end{tabular} & $11.11 \%$ & $-0.24[-0.73,0.25]$ \\
\hline Hammond 2001 & 65 & $16.4(5.8)$ & 62 & $16.1(5.4)$ & + & $18.29 \%$ & $0.05[-0.29,0.4]$ \\
\hline Jensen 1997 & 29 & $13.4(5.7)$ & 25 & $12.8(7.5)$ & & $9.57 \%$ & $0.09[-0.45,0.62]$ \\
\hline Turner 2006 & 72 & $6(4.2)$ & 70 & $8.2(3.9)$ & - & $19.23 \%$ & $-0.54[-0.87,-0.2]$ \\
\hline Zautra 2008 & 51 & $2(0.7)$ & 40 & $2.1(0.8)$ & $\longrightarrow$ & $14.3 \%$ & $-0.13[-0.55,0.28]$ \\
\hline Total $* \star \star$ & 382 & & 353 & & & $100 \%$ & $-0.18[-0.36,0]$ \\
\hline \multicolumn{8}{|c|}{ Heterogeneity: $\mathrm{Tau}^{2}=0.02 ; \mathrm{Chi}^{2}=7.23, \mathrm{df}=5(\mathrm{P}=0.2) ; \mathrm{I}^{2}=30.84 \%$} \\
\hline \multicolumn{3}{|c|}{ Test for overall effect: $Z=1.92(P=0.05)$} & & & & & \\
\hline
\end{tabular}

\section{Comparison 2. Cognitive behavioural vs active control follow-up}

\begin{tabular}{lllll}
\hline $\begin{array}{l}\text { Outcome or sub- } \\
\text { group title }\end{array}$ & $\begin{array}{l}\text { No. of } \\
\text { studies }\end{array}$ & $\begin{array}{l}\text { No. of } \\
\text { partici- } \\
\text { pants }\end{array}$ & Statistical method & Effect size \\
\hline 1 Pain & 11 & 1261 & Std. Mean Difference (IV, Random, 95\% CI) & $-0.08[-0.23,0.06]$ \\
\hline 2 Disability & 12 & 1295 & Std. Mean Difference (IV, Random, 95\% Cl) & $-0.15[-0.28,-0.02]$ \\
\hline 3 Mood & 11 & 1261 & Std. Mean Difference (IV, Random, 95\% CI) & $-0.07[-0.18,0.05]$ \\
\hline 4 Catastrophising & 2 & 282 & Std. Mean Difference (IV, Random, 95\% CI) & $0.06[-0.18,0.29]$ \\
\hline
\end{tabular}


Analysis 2.1. Comparison 2 Cognitive behavioural vs active control follow-up, Outcome 1 Pain.

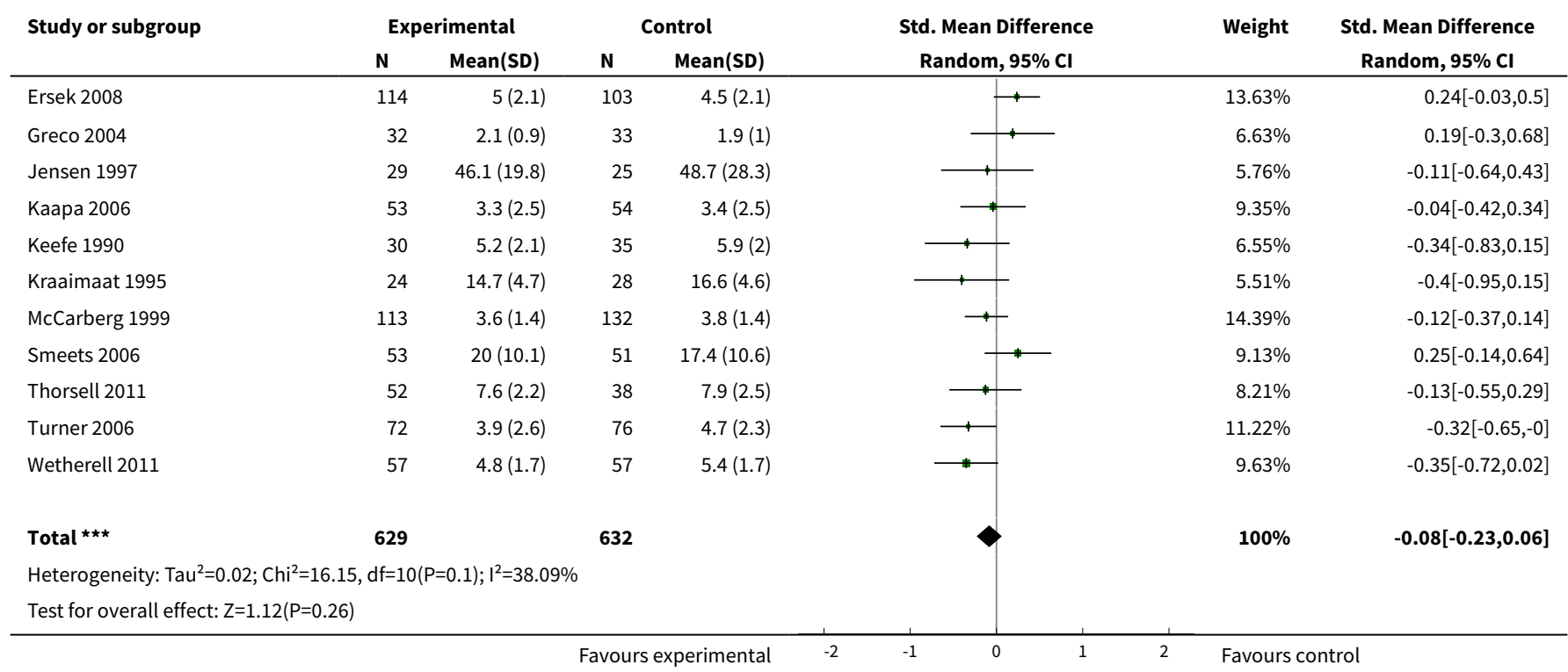

Analysis 2.2. Comparison 2 Cognitive behavioural vs active control follow-up, Outcome 2 Disability.

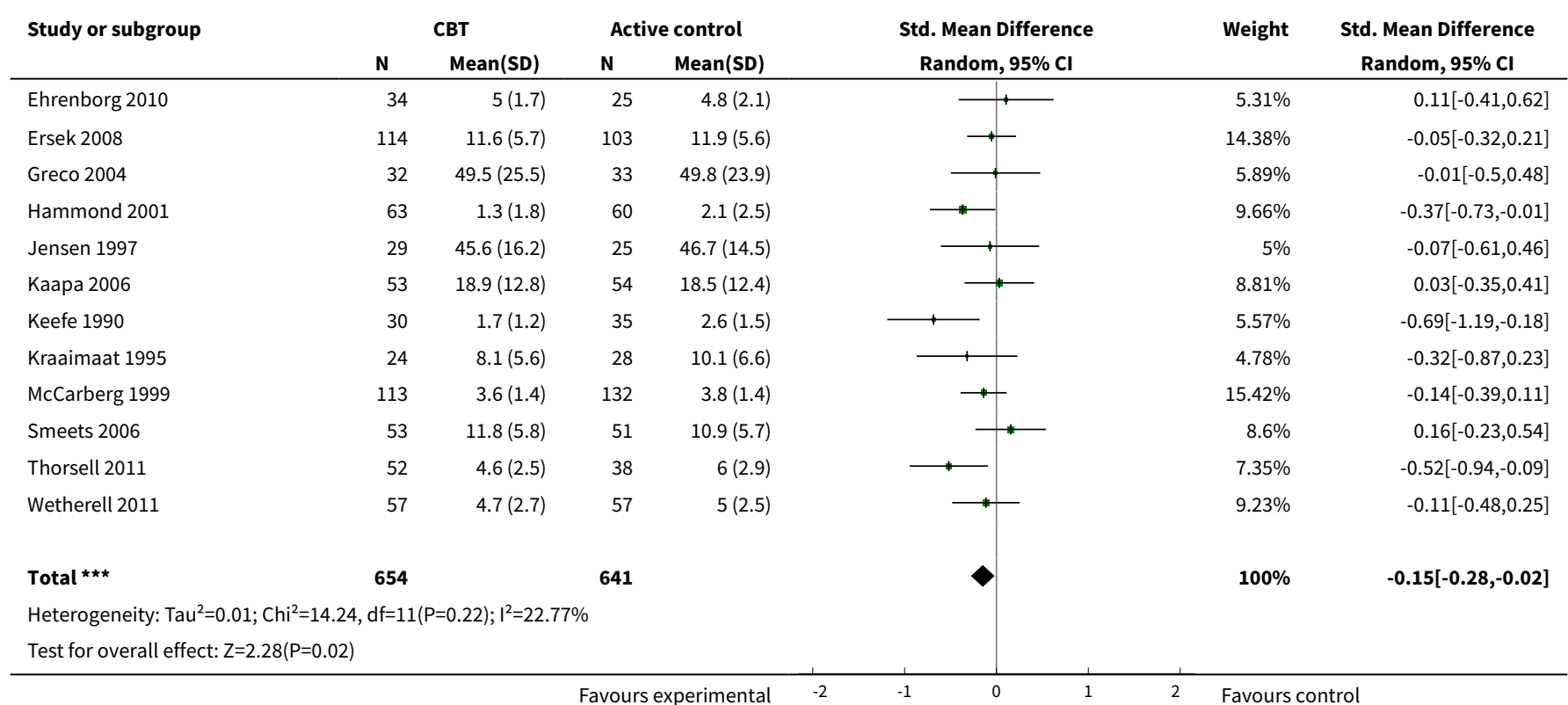

Analysis 2.3. Comparison 2 Cognitive behavioural vs active control follow-up, Outcome 3 Mood.

\begin{tabular}{|c|c|c|c|c|c|c|c|}
\hline \multirow[t]{2}{*}{ Study or subgroup } & \multicolumn{2}{|c|}{ СВT } & \multicolumn{2}{|c|}{ Active control } & \multirow{2}{*}{$\begin{array}{c}\text { Std. Mean Difference } \\
\text { Random, } 95 \% \mathrm{Cl}\end{array}$} & \multirow[t]{2}{*}{ Weight } & \multirow{2}{*}{$\begin{array}{c}\text { Std. Mean Difference } \\
\text { Random, } 95 \% \mathrm{Cl}\end{array}$} \\
\hline & $\mathbf{N}$ & $\operatorname{Mean}(S D)$ & $\mathbf{N}$ & $\operatorname{Mean}(S D)$ & & & \\
\hline Ersek 2008 & 114 & $11.2(3.1)$ & 103 & $10.8(2.7)$ & 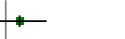 & $17.25 \%$ & $0.14[-0.13,0.4]$ \\
\hline
\end{tabular}




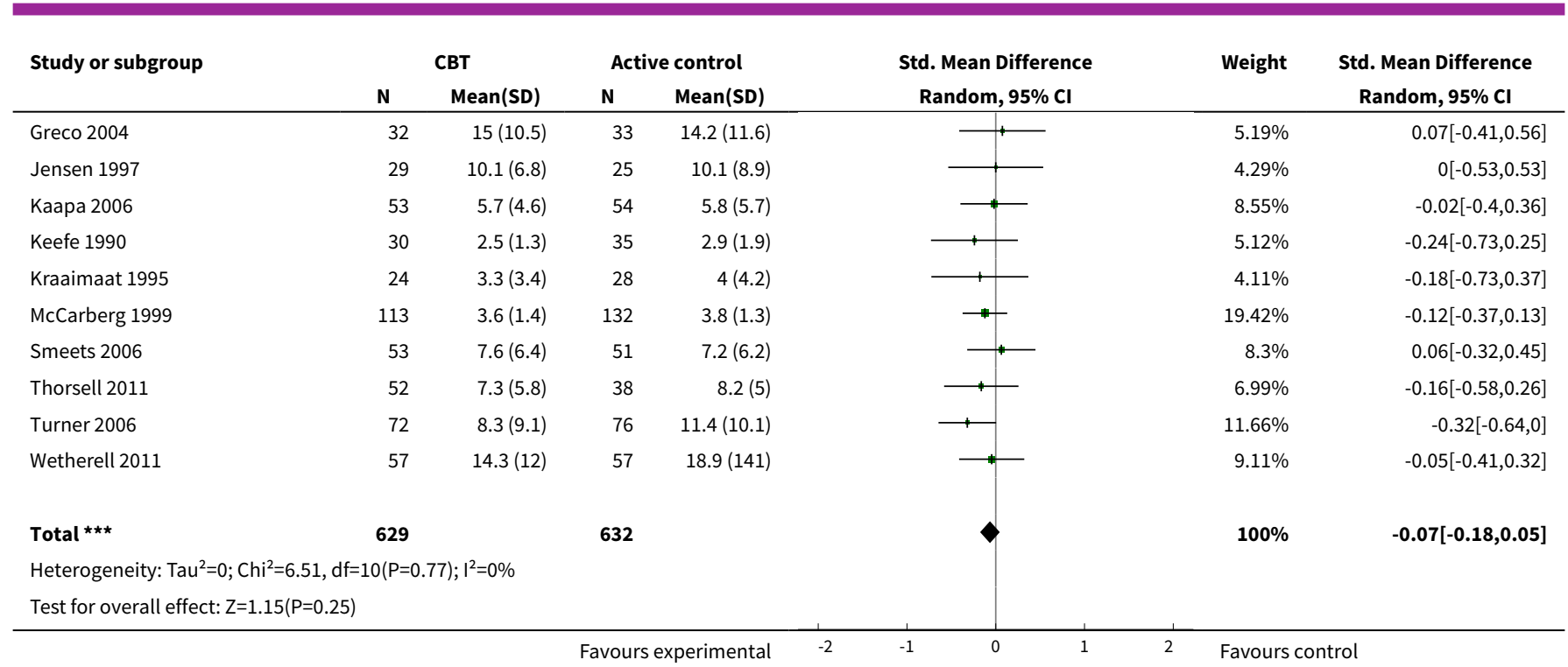

Analysis 2.4. Comparison 2 Cognitive behavioural vs active control follow-up, Outcome 4 Catastrophising.

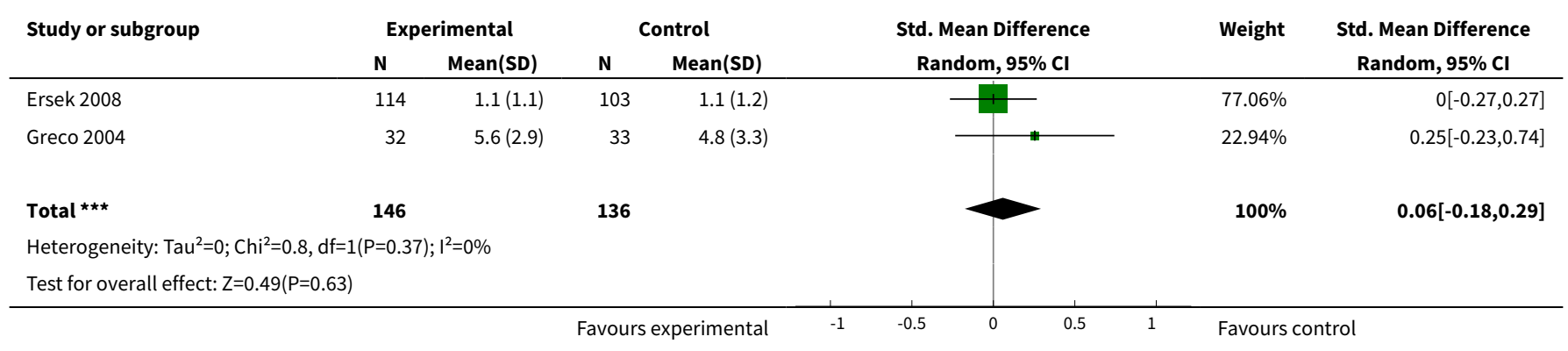

\section{Comparison 3. Cognitive behavioural vs treatment as usual}

\begin{tabular}{lllll}
\hline $\begin{array}{l}\text { Outcome or sub- } \\
\text { group title }\end{array}$ & $\begin{array}{l}\text { No. of } \\
\text { studies }\end{array}$ & $\begin{array}{l}\text { No. of } \\
\text { partici- } \\
\text { pants }\end{array}$ & Statistical method & Effect size \\
\hline 1 Pain & 16 & 1148 & Std. Mean Difference (IV, Random, 95\% CI) & $-0.21[-0.37,-0.05]$ \\
\hline 2 Disability & 15 & 1105 & Std. Mean Difference (IV, Random, 95\% Cl) & $-0.26[-0.47,-0.04]$ \\
\hline 3 Mood & 12 & 899 & Std. Mean Difference (IV, Random, 95\% CI) & $-0.38[-0.57,-0.18]$ \\
\hline 4 Catastrophising & 5 & 308 & Std. Mean Difference (IV, Random, 95\% Cl) & $-0.53[-0.76,-0.31]$ \\
\hline
\end{tabular}


Analysis 3.1. Comparison 3 Cognitive behavioural vs treatment as usual, Outcome 1 Pain.

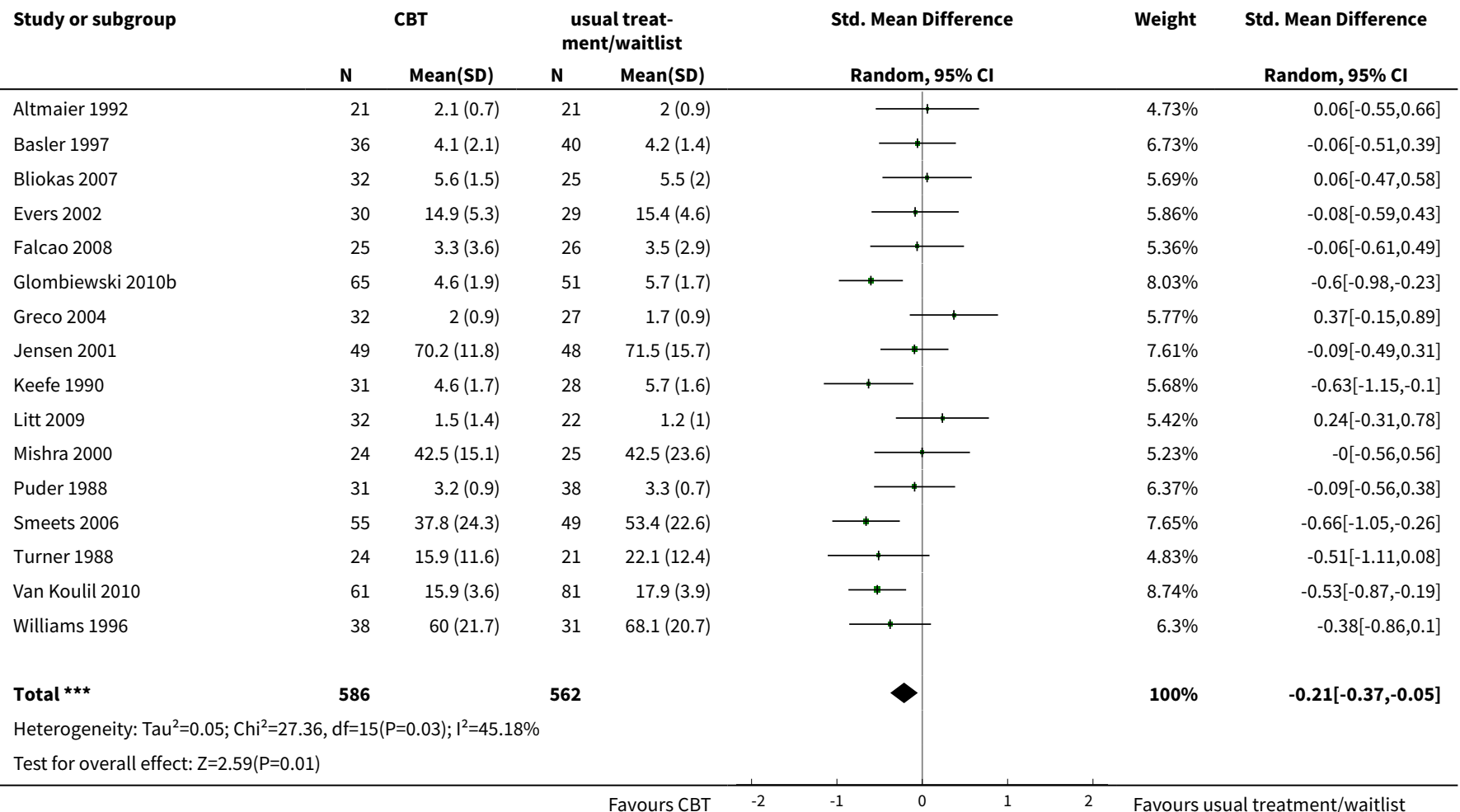

Analysis 3.2. Comparison 3 Cognitive behavioural vs treatment as usual, Outcome 2 Disability.

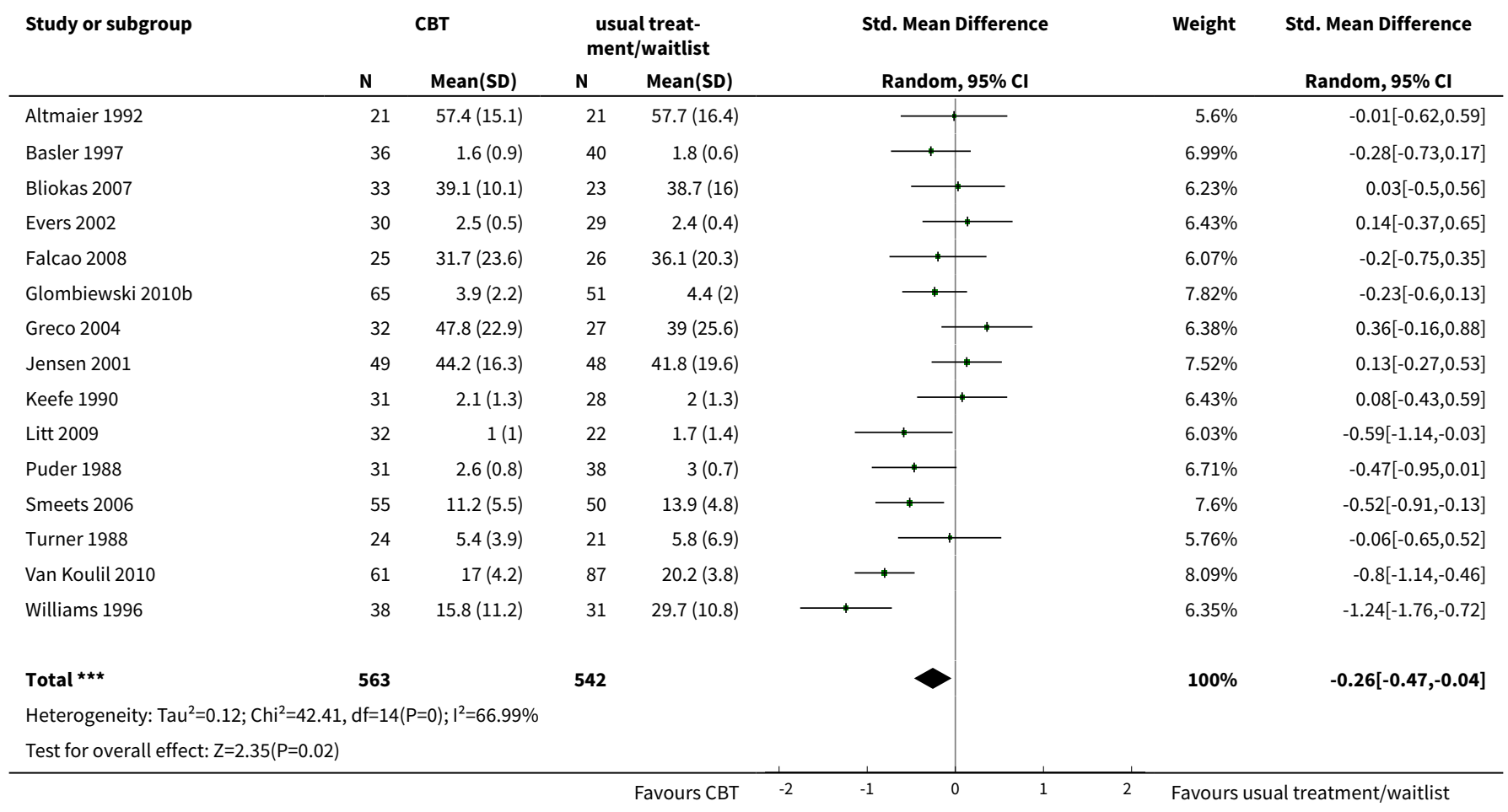


Analysis 3.3. Comparison 3 Cognitive behavioural vs treatment as usual, Outcome 3 Mood.

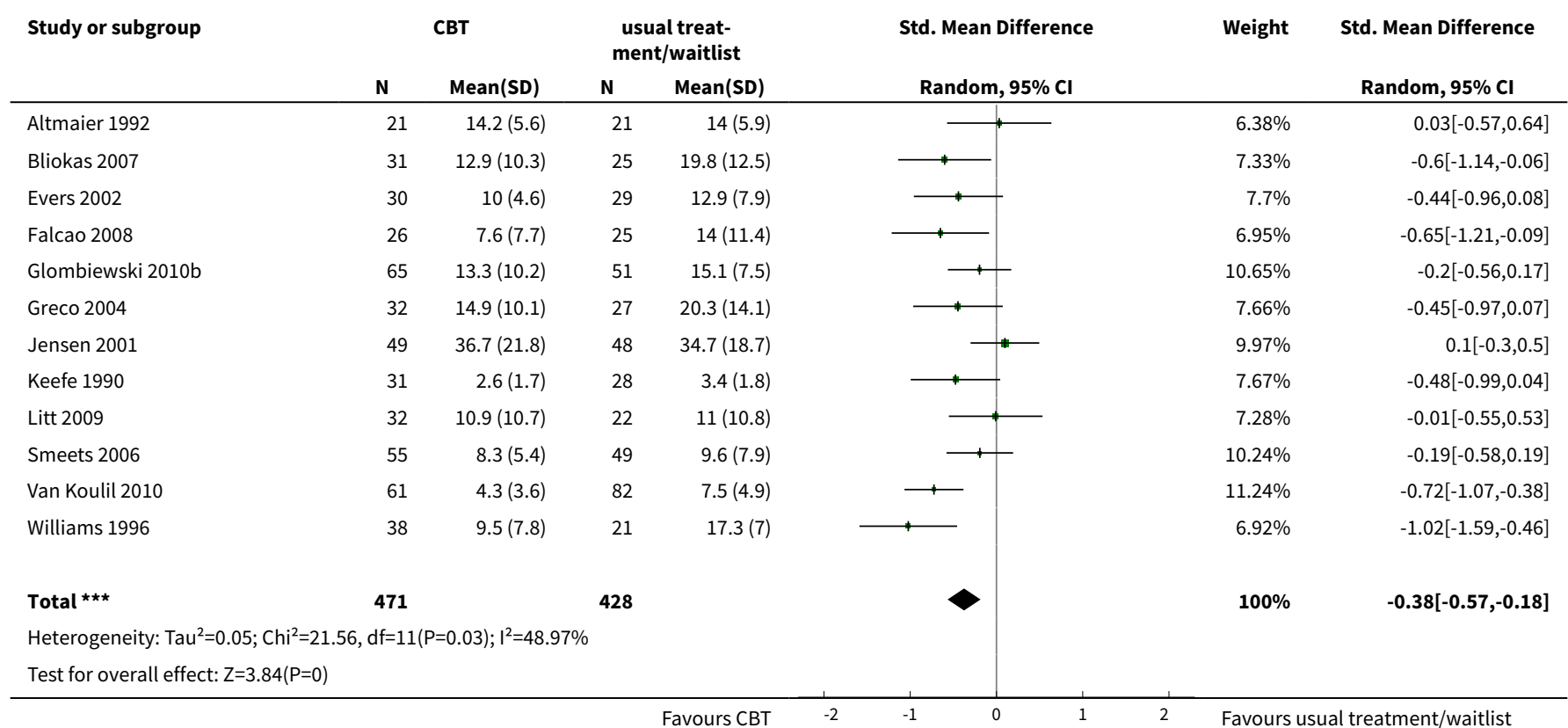

Analysis 3.4. Comparison 3 Cognitive behavioural vs treatment as usual, Outcome 4 Catastrophising.

\begin{tabular}{|c|c|c|c|c|c|c|c|}
\hline \multirow{3}{*}{$\begin{array}{l}\text { Study or subgroup } \\
\text { Basler } 1997\end{array}$} & \multicolumn{2}{|c|}{ Treatment } & \multicolumn{2}{|c|}{ Control } & \multirow{2}{*}{$\begin{array}{c}\text { Std. Mean Difference } \\
\text { Random, } 95 \% \mathrm{Cl}\end{array}$} & \multirow[t]{2}{*}{ Weight } & \multirow{2}{*}{$\begin{array}{c}\text { Std. Mean Difference } \\
\text { Random, } 95 \% \mathrm{Cl}\end{array}$} \\
\hline & $\mathbf{N}$ & Mean(SD) & $\mathbf{N}$ & Mean(SD) & & & \\
\hline & 36 & $2(0.7)$ & 40 & $2.4(0.8)$ & $\because-$ & $24.93 \%$ & $-0.52[-0.98,-0.07]$ \\
\hline Evers 2002 & 30 & $11.3(3.8)$ & 29 & $13(3.8)$ & $\because$ & $19.59 \%$ & $-0.44[-0.96,0.08]$ \\
\hline Greco 2004 & 32 & $5.3(3.1)$ & 27 & $6.7(4)$ & $\longrightarrow$ & $19.57 \%$ & $-0.39[-0.91,0.13]$ \\
\hline Turner 1988 & 24 & $18.2(14.1)$ & 21 & $23.3(21.8)$ & $\longrightarrow$ & $15.11 \%$ & $-0.28[-0.87,0.31]$ \\
\hline Williams 1996 & 38 & $9.7(8.1)$ & 31 & $17.4(7.8)$ & 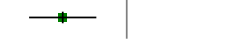 & $20.79 \%$ & $-0.96[-1.46,-0.45]$ \\
\hline Total *** & 160 & & 148 & & & $100 \%$ & $-0.53[-0.76,-0.31]$ \\
\hline \multicolumn{8}{|c|}{ Heterogeneity: $\operatorname{Tau}^{2}=0 ; \mathrm{Chi}^{2}=3.86, \mathrm{df}=4(\mathrm{P}=0.42) ; \mathrm{I}^{2}=0 \%$} \\
\hline \multicolumn{3}{|c|}{ Test for overall effect: $Z=4.58(P<0.0001)$} & & & & & \\
\hline
\end{tabular}

\section{Comparison 4. Cognitive behavioural vs treatment as usual follow-up}

\begin{tabular}{lllll}
\hline $\begin{array}{l}\text { Outcome or sub- } \\
\text { group title }\end{array}$ & $\begin{array}{l}\text { No. of } \\
\text { studies }\end{array}$ & $\begin{array}{l}\text { No. of } \\
\text { partici- } \\
\text { pants }\end{array}$ & Statistical method & Effect size \\
\hline 1 Pain & 7 & 635 & Std. Mean Difference (IV, Random, 95\% Cl) & $-0.09[-0.25,0.08]$ \\
\hline 2 Disability & 6 & 450 & Std. Mean Difference (IV, Random, 95\% Cl) & $-0.13[-0.51,0.25]$ \\
\hline 3 Mood & 7 & 637 & Std. Mean Difference (IV, Random, 95\% Cl) & $-0.26[-0.51,-0.00]$ \\
\hline
\end{tabular}




\begin{tabular}{lllll}
\hline $\begin{array}{l}\text { Outcome or sub- } \\
\text { group title }\end{array}$ & $\begin{array}{l}\text { No. of } \\
\text { studies }\end{array}$ & $\begin{array}{l}\text { No. of } \\
\text { partici- } \\
\text { pants }\end{array}$ & Statistical method & Effect size \\
\hline 4 Catastrophising & 1 & & Std. Mean Difference (IV, Random, 95\% Cl) & Totals not selected \\
\hline
\end{tabular}

Analysis 4.1. Comparison 4 Cognitive behavioural vs treatment as usual follow-up, Outcome 1 Pain.

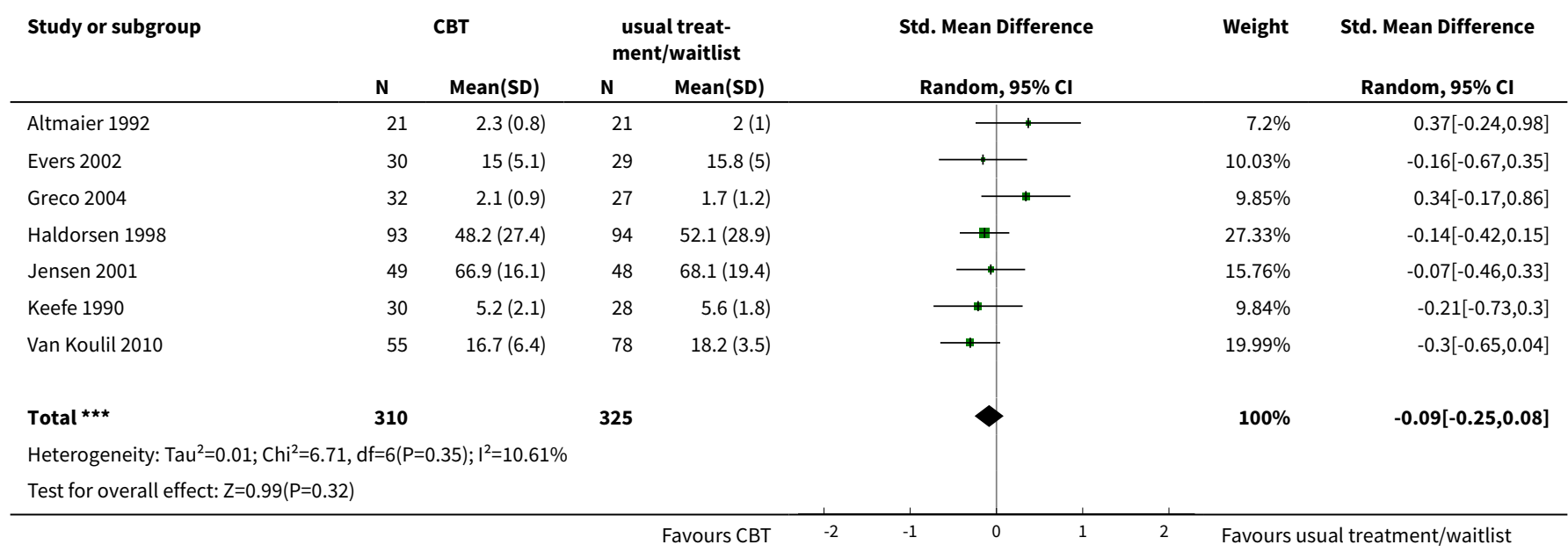

Analysis 4.2. Comparison 4 Cognitive behavioural vs treatment as usual follow-up, Outcome 2 Disability.

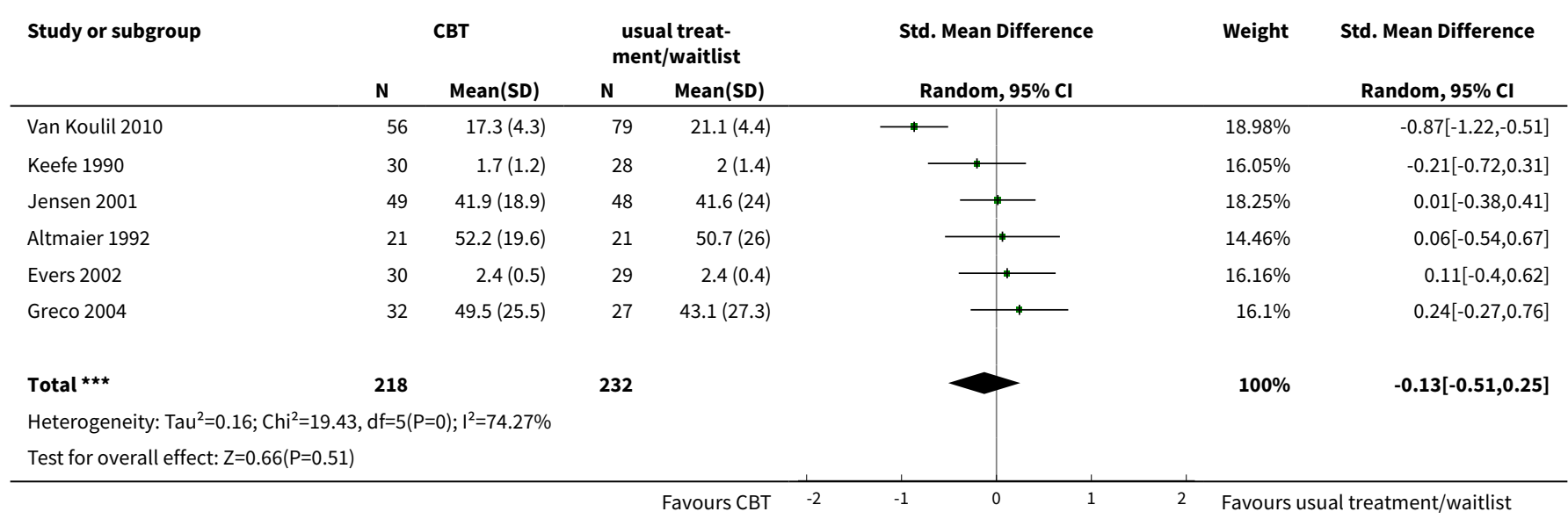

Analysis 4.3. Comparison 4 Cognitive behavioural vs treatment as usual follow-up, Outcome 3 Mood.

\begin{tabular}{|c|c|c|c|c|c|c|c|c|}
\hline \multirow[t]{2}{*}{ Study or subgroup } & \multicolumn{2}{|c|}{ CBT } & \multicolumn{2}{|c|}{$\begin{array}{l}\text { usual treat- } \\
\text { ment/waitlist }\end{array}$} & & \multirow{2}{*}{$\begin{array}{l}\text { Std. Mean Difference } \\
\text { Random, } 95 \% \mathrm{Cl}\end{array}$} & \multirow[t]{2}{*}{ Weight } & \multirow{2}{*}{$\begin{array}{l}\text { Std. Mean Difference } \\
\text { Random, } 95 \% \mathrm{Cl}\end{array}$} \\
\hline & $\mathbf{N}$ & $\operatorname{Mean}(S D)$ & $\mathbf{N}$ & Mean(SD) & & & & \\
\hline Altmaier 1992 & 21 & $16.2(4.2)$ & 21 & $15(6.2)$ & & \begin{tabular}{l|l}
1 \\
\end{tabular} & $10.42 \%$ & $0.23[-0.38,0.84]$ \\
\hline
\end{tabular}




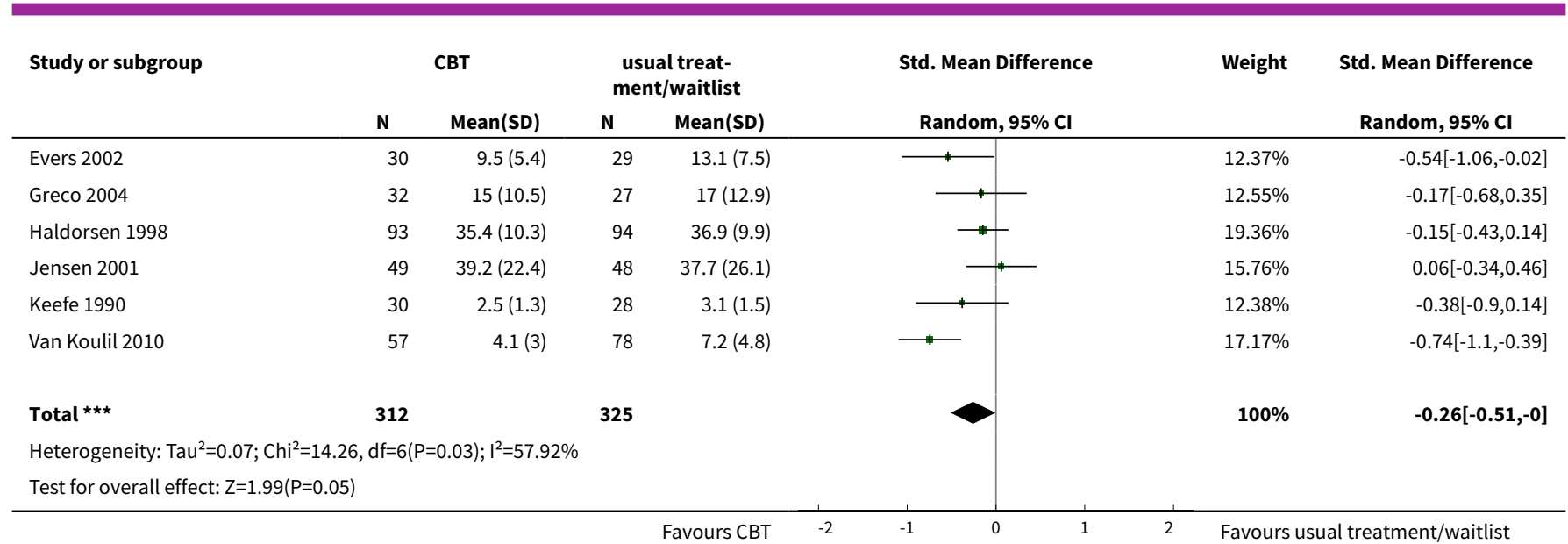

Analysis 4.4. Comparison 4 Cognitive behavioural vs treatment as usual follow-up, Outcome 4 Catastrophising.

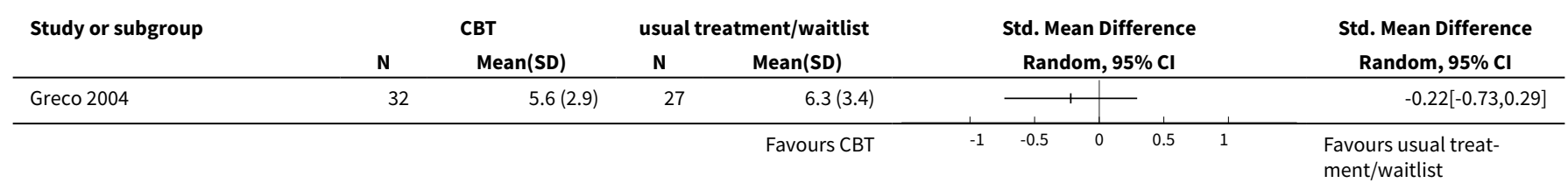

\section{Comparison 5. Behavioural vs active control post-treatment}

\begin{tabular}{lllll}
\hline $\begin{array}{l}\text { Outcome or sub- } \\
\text { group title }\end{array}$ & $\begin{array}{l}\text { No. of } \\
\text { studies }\end{array}$ & $\begin{array}{l}\text { No. of } \\
\text { partici- } \\
\text { pants }\end{array}$ & Statistical method & Effect size \\
\hline 1 Pain & 1 & & Std. Mean Difference (IV, Random, 95\% Cl) & Totals not selected \\
\hline 2 Disability & 2 & 148 & Std. Mean Difference (IV, Random, 95\% Cl) & $-0.26[-0.58,0.07]$ \\
\hline 3 Mood & 1 & & Std. Mean Difference (IV, Random, 95\% Cl) & Totals not selected \\
\hline 4 Catastrophising & 2 & 146 & Std. Mean Difference (IV, Random, 95\% Cl) & $-0.28[-0.60,0.05]$ \\
\hline
\end{tabular}

Analysis 5.1. Comparison 5 Behavioural vs active control post-treatment, Outcome 1 Pain.

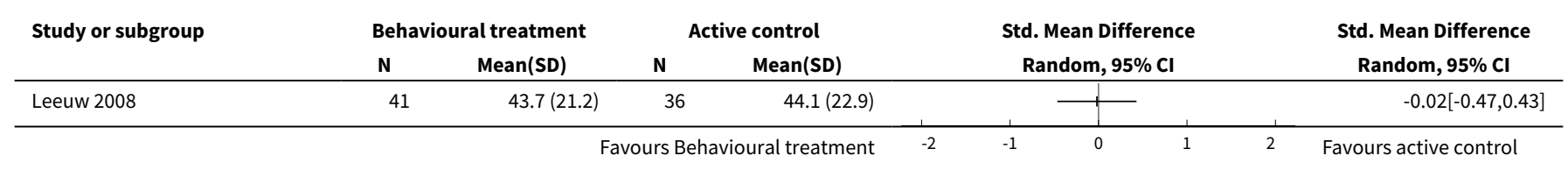


Analysis 5.2. Comparison 5 Behavioural vs active control post-treatment, Outcome 2 Disability.

\begin{tabular}{|c|c|c|c|c|c|c|c|}
\hline \multirow[t]{2}{*}{ Study or subgroup } & \multicolumn{2}{|c|}{$\begin{array}{l}\text { Behaviour- } \\
\text { al treatment }\end{array}$} & \multicolumn{2}{|c|}{ Active control } & \multirow{2}{*}{$\begin{array}{l}\text { Std. Mean Difference } \\
\text { Random, 95\% CI }\end{array}$} & \multirow[t]{2}{*}{ Weight } & \multirow{2}{*}{$\begin{array}{c}\text { Std. Mean Difference } \\
\text { Random, } 95 \% \mathrm{Cl} \\
\end{array}$} \\
\hline & $\mathbf{N}$ & Mean(SD) & $\mathbf{N}$ & Mean(SD) & & & \\
\hline Leeuw 2008 & 41 & $35.9(20.5)$ & 36 & $41.7(22.6)$ & $1-$ & $51.9 \%$ & $-0.27[-0.72,0.18]$ \\
\hline Nicassio 1997 & 36 & $0.4(0.1)$ & 35 & $0.4(0.1)$ & \begin{tabular}{l|l}
1 \\
+1
\end{tabular} & $48.1 \%$ & $-0.25[-0.71,0.22]$ \\
\hline Total *** & 77 & & 71 & & & $100 \%$ & $-0.26[-0.58,0.07]$ \\
\hline \multicolumn{8}{|c|}{ Heterogeneity: Tau $^{2}=0 ; \mathrm{Chi}^{2}=0, \mathrm{df}=1(\mathrm{P}=0.95) ; \mathrm{I}^{2}=0 \%$} \\
\hline \multicolumn{8}{|c|}{ Test for overall effect: $Z=1.56(P=0.12)$} \\
\hline
\end{tabular}

Analysis 5.3. Comparison 5 Behavioural vs active control post-treatment, Outcome 3 Mood.

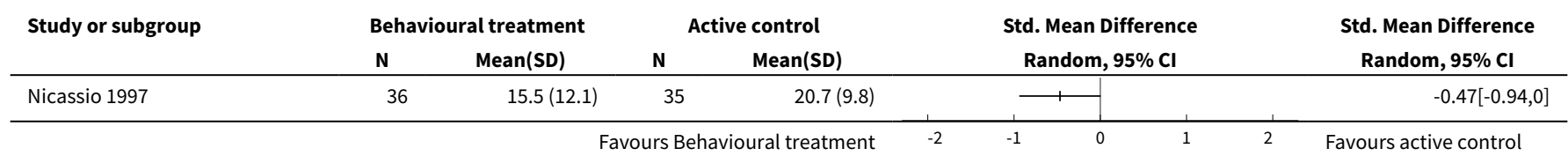

Analysis 5.4. Comparison 5 Behavioural vs active control post-treatment, Outcome 4 Catastrophising.

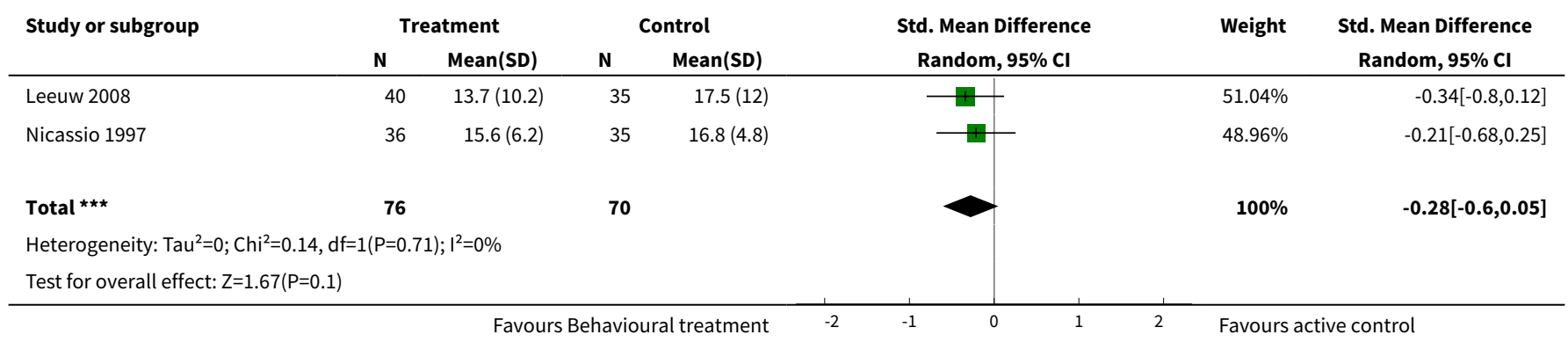

Comparison 6. Behavioural vs active control follow-up

\begin{tabular}{lllll}
\hline $\begin{array}{l}\text { Outcome or sub- } \\
\text { group title }\end{array}$ & $\begin{array}{l}\text { No. of } \\
\text { studies }\end{array}$ & $\begin{array}{l}\text { No. of } \\
\text { partici- } \\
\text { pants }\end{array}$ & Statistical method & Effect size \\
\hline 1 Pain & 1 & & Std. Mean Difference (IV, Random, 95\% Cl) & Totals not selected \\
\hline 2 Disability & 2 & 144 & Std. Mean Difference (IV, Random, 95\% Cl) & $-0.17[-0.50,0.16]$ \\
\hline 3 Mood & 1 & & Std. Mean Difference (IV, Random, 95\% Cl) & Totals not selected \\
\hline 4 Catastrophising & 1 & & Std. Mean Difference (IV, Random, 95\% Cl) & Totals not selected \\
\hline
\end{tabular}


Analysis 6.1. Comparison 6 Behavioural vs active control follow-up, Outcome 1 Pain.

\begin{tabular}{|c|c|c|c|c|c|c|}
\hline \multirow[t]{2}{*}{ Study or subgroup } & \multicolumn{2}{|c|}{ Behavioural treatment } & \multicolumn{2}{|c|}{ Active control } & \multirow{2}{*}{$\begin{array}{c}\text { Std. Mean Difference } \\
\text { Random, } 95 \% \mathrm{Cl}\end{array}$} & \multirow{2}{*}{$\begin{array}{c}\text { Std. Mean Difference } \\
\text { Random, } 95 \% \mathrm{Cl}\end{array}$} \\
\hline & $\mathbf{N}$ & Mean(SD) & $\mathbf{N}$ & $\operatorname{Mean}(S D)$ & & \\
\hline Leeuw 2008 & 38 & $41.2(22.3)$ & 35 & $40.5(22.3)$ & 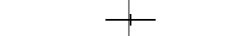 & $0.03[-0.43,0.49]$ \\
\hline
\end{tabular}

Analysis 6.2. Comparison 6 Behavioural vs active control follow-up, Outcome 2 Disability.

\begin{tabular}{|c|c|c|c|c|c|c|c|}
\hline \multirow[t]{2}{*}{ Study or subgroup } & \multicolumn{2}{|c|}{$\begin{array}{l}\text { Behaviour- } \\
\text { al treatment }\end{array}$} & \multicolumn{2}{|c|}{ Active control } & \multirow{2}{*}{$\begin{array}{l}\text { Std. Mean Difference } \\
\text { Random, } 95 \% \mathrm{Cl}\end{array}$} & \multirow[t]{2}{*}{ Weight } & \multirow{2}{*}{$\begin{array}{l}\text { Std. Mean Difference } \\
\text { Random, } 95 \% \mathrm{Cl}\end{array}$} \\
\hline & $\mathbf{N}$ & $\operatorname{Mean}(S D)$ & $\mathbf{N}$ & $\operatorname{Mean}(S D)$ & & & \\
\hline Leeuw 2008 & 38 & 39 (20.9) & 35 & $41.9(19.3)$ & \begin{tabular}{l|l}
+1 \\
+1
\end{tabular} & $50.72 \%$ & $-0.14[-0.6,0.32]$ \\
\hline Nicassio 1997 & 36 & $0.4(0.1)$ & 35 & $0.4(0.1)$ & $\longrightarrow$ & $49.28 \%$ & $-0.2[-0.66,0.27]$ \\
\hline 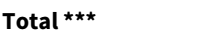 & 74 & & 70 & & & $100 \%$ & $-0.17[-0.5,0.16]$ \\
\hline Test for overall effect & & & & & & & \\
\hline
\end{tabular}

Analysis 6.3. Comparison 6 Behavioural vs active control follow-up, Outcome 3 Mood.

\begin{tabular}{|c|c|c|c|c|c|c|}
\hline \multirow[t]{2}{*}{ Study or subgroup } & \multicolumn{2}{|c|}{ Behavioural treatment } & \multicolumn{2}{|c|}{ Active control } & \multirow{2}{*}{$\begin{array}{c}\text { Std. Mean Difference } \\
\text { Random, } 95 \% \mathrm{Cl} \\
\end{array}$} & \multirow{2}{*}{$\begin{array}{c}\text { Std. Mean Difference } \\
\text { Random, } 95 \% \mathrm{Cl}\end{array}$} \\
\hline & $\mathbf{N}$ & Mean(SD) & $\mathbf{N}$ & Mean(SD) & & \\
\hline Nicassio 1997 & 36 & $13.7(10.1)$ & 35 & $17.7(11.3)$ & 1 & $-0.37[-0.84,0.1]$ \\
\hline
\end{tabular}

Analysis 6.4. Comparison 6 Behavioural vs active control follow-up, Outcome 4 Catastrophising.

\begin{tabular}{|c|c|c|c|c|c|c|c|c|}
\hline \multirow[t]{2}{*}{ Study or subgroup } & \multicolumn{2}{|c|}{ Behavioural treatment } & \multicolumn{2}{|c|}{ Active control } & \multirow{2}{*}{\multicolumn{3}{|c|}{$\begin{array}{c}\text { Std. Mean Difference } \\
\text { Random, } 95 \% \mathrm{CI}\end{array}$}} & \multirow{2}{*}{$\begin{array}{c}\text { Std. Mean Difference } \\
\text { Random, } 95 \% \mathrm{CI}\end{array}$} \\
\hline & $\mathbf{N}$ & Mean(SD) & $\mathbf{N}$ & Mean(SD) & & & & \\
\hline Leeuw 2008 & 38 & $14.7(10.8)$ & 35 & $15.3(9.4)$ & & & & $-0.06[-0.52,0.4]$ \\
\hline
\end{tabular}

Comparison 7. Behavioural vs treatment as usual post-treatment

\begin{tabular}{lllll}
\hline $\begin{array}{l}\text { Outcome or sub- } \\
\text { group title }\end{array}$ & $\begin{array}{l}\text { No. of } \\
\text { studies }\end{array}$ & $\begin{array}{l}\text { No. of } \\
\text { partici- } \\
\text { pants }\end{array}$ & Statistical method & Effect size \\
\hline 1 Pain & 5 & 484 & Std. Mean Difference (IV, Random, 95\% CI) & $-0.27[-0.79,0.24]$ \\
\hline 2 Disability & 5 & 504 & Std. Mean Difference (IV, Random, 95\% Cl) & $-0.41[-0.98,0.16]$ \\
\hline 3 Mood & 3 & 278 & Std. Mean Difference (IV, Random, 95\% CI) & $-0.53[-1.42,0.35]$ \\
\hline
\end{tabular}




\begin{tabular}{lllll}
\hline $\begin{array}{l}\text { Outcome or sub- } \\
\text { group title }\end{array}$ & $\begin{array}{l}\text { No. of } \\
\text { studies }\end{array}$ & $\begin{array}{l}\text { No. of } \\
\text { partici- } \\
\text { pants }\end{array}$ & Statistical method & Effect size \\
\hline 4 Catastrophising & 3 & 269 & Std. Mean Difference (IV, Random, 95\% Cl) & $-0.72[-1.43,-0.01]$ \\
\hline
\end{tabular}

Analysis 7.1. Comparison 7 Behavioural vs treatment as usual post-treatment, Outcome 1 Pain.

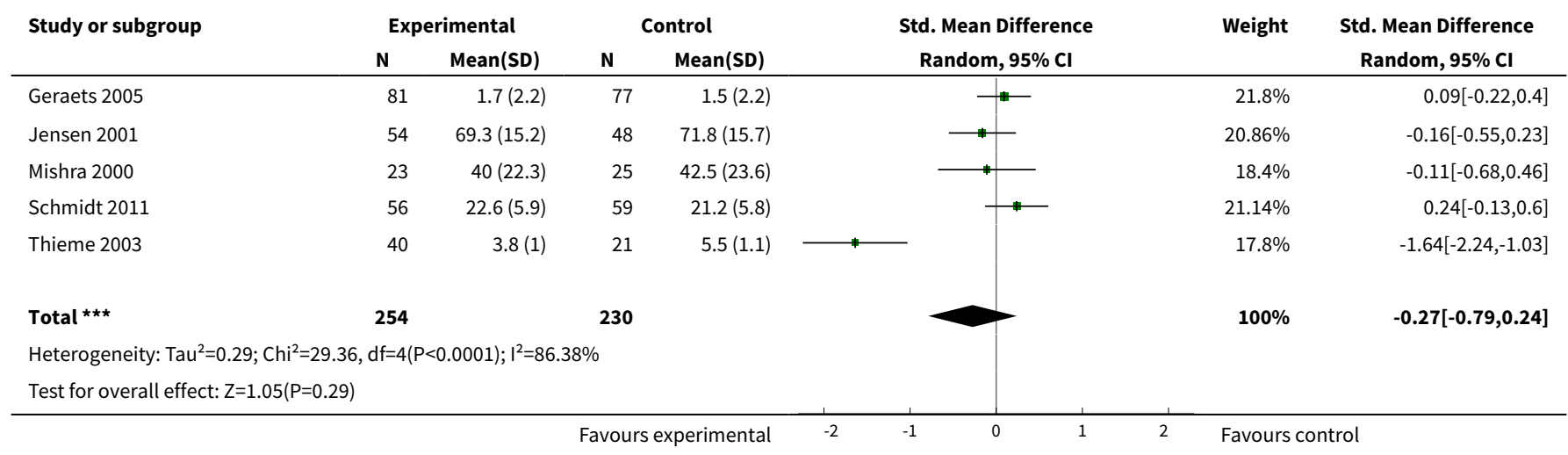

Analysis 7.2. Comparison 7 Behavioural vs treatment as usual post-treatment, Outcome 2 Disability.

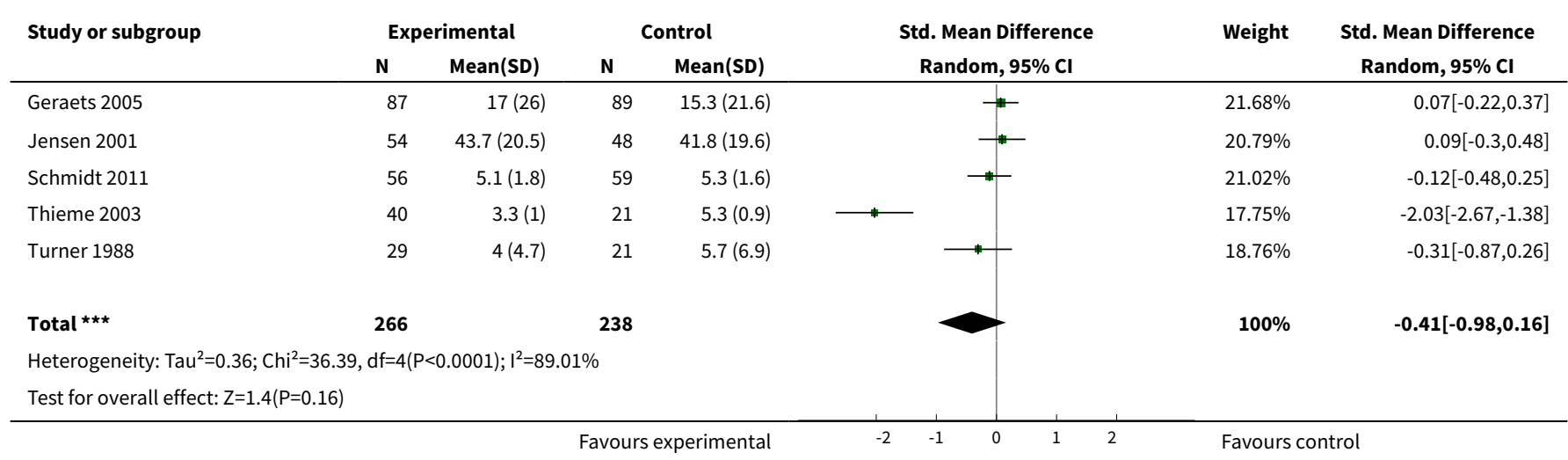

Analysis 7.3. Comparison 7 Behavioural vs treatment as usual post-treatment, Outcome 3 Mood.

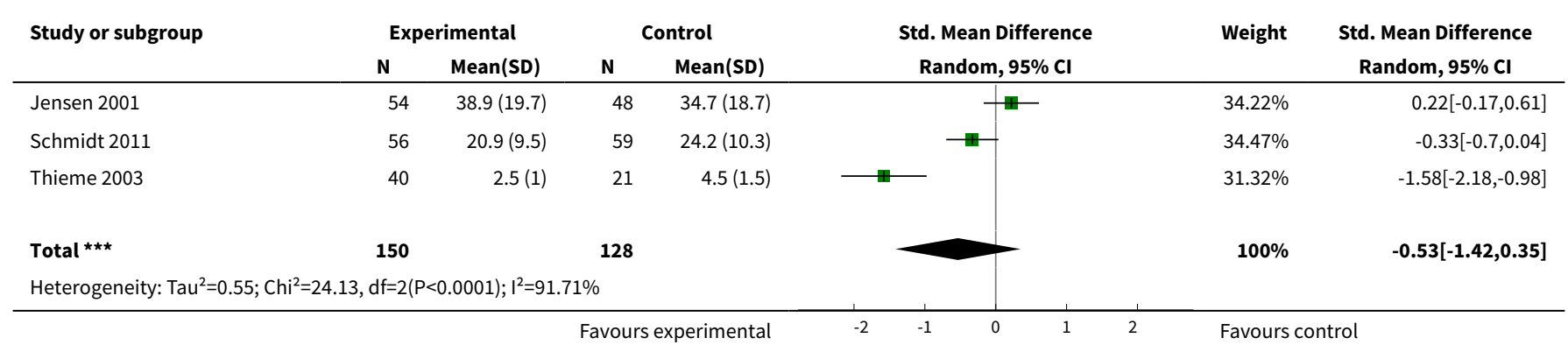




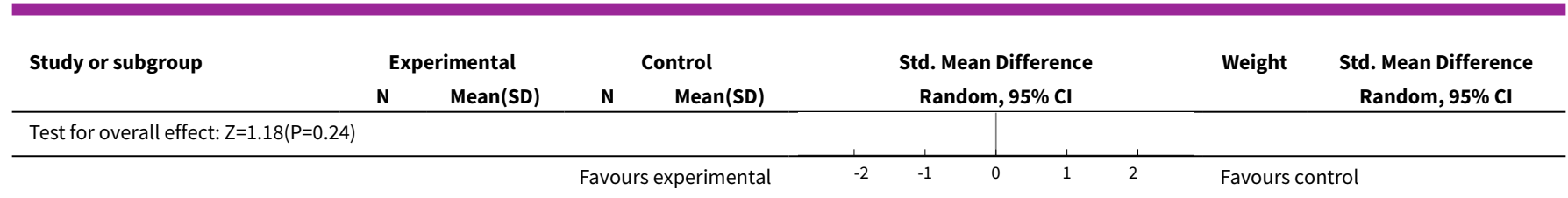

Analysis 7.4. Comparison 7 Behavioural vs treatment as usual post-treatment, Outcome 4 Catastrophising.

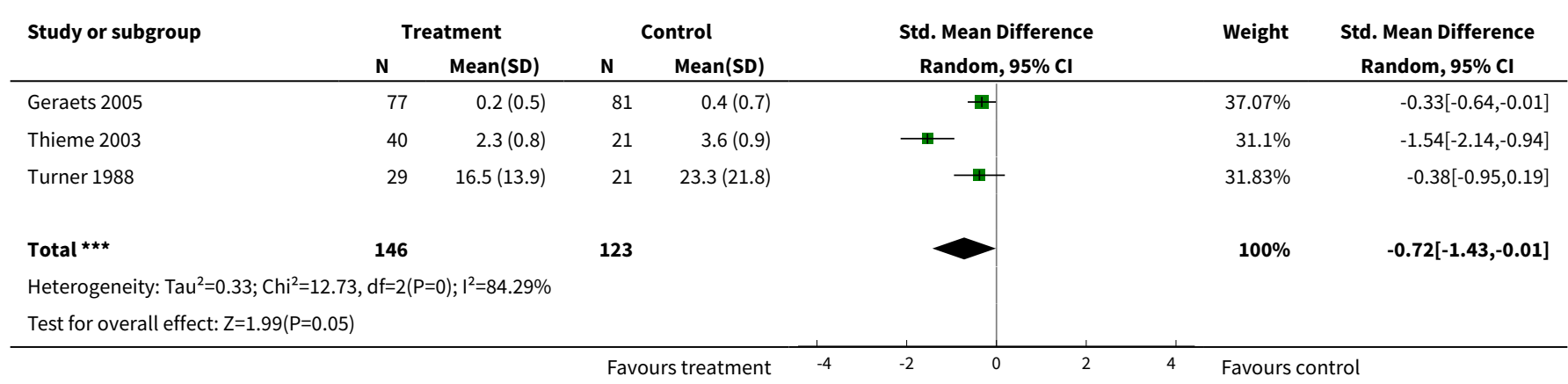

\section{Comparison 8. Behavioural vs treatment as usual follow-up}

\begin{tabular}{lllll}
\hline $\begin{array}{l}\text { Outcome or sub- } \\
\text { group title }\end{array}$ & $\begin{array}{l}\text { No. of } \\
\text { studies }\end{array}$ & $\begin{array}{l}\text { No. of } \\
\text { partici- } \\
\text { pants }\end{array}$ & Statistical method & Effect size \\
\hline 1 Pain & 2 & 182 & Std. Mean Difference (IV, Random, 95\% CI) & $-0.03[-0.32,0.26]$ \\
\hline 2 Disability & 3 & 336 & Std. Mean Difference (IV, Random, 95\% Cl) & $-0.54[-1.51,0.44]$ \\
\hline 3 Mood & 2 & 160 & Std. Mean Difference (IV, Random, 95\% CI) & $-0.65[-2.07,0.77]$ \\
\hline
\end{tabular}

Analysis 8.1. Comparison 8 Behavioural vs treatment as usual follow-up, Outcome 1 Pain.

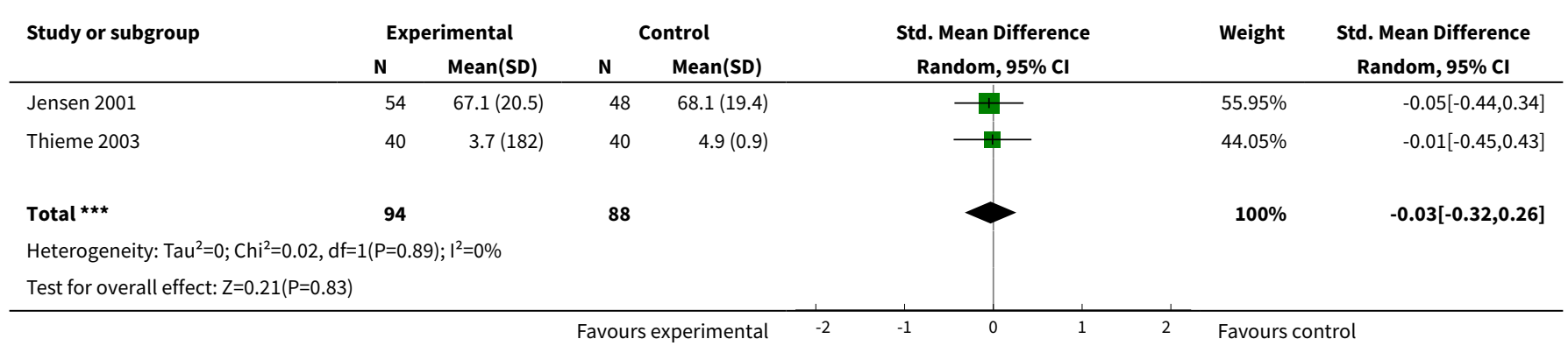


Analysis 8.2. Comparison 8 Behavioural vs treatment as usual follow-up, Outcome 2 Disability.

\begin{tabular}{|c|c|c|c|c|c|c|c|}
\hline \multirow[t]{2}{*}{ Study or subgroup } & \multicolumn{2}{|c|}{ Experimental } & \multicolumn{2}{|c|}{ Control } & \multirow{2}{*}{$\begin{array}{c}\text { Std. Mean Difference } \\
\text { Random, } 95 \% \mathrm{Cl}\end{array}$} & \multirow[t]{2}{*}{ Weight } & \multirow{2}{*}{$\begin{array}{c}\text { Std. Mean Difference } \\
\text { Random, } 95 \% \mathrm{Cl}\end{array}$} \\
\hline & $\mathbf{N}$ & Mean(SD) & $\mathbf{N}$ & Mean(SD) & & & \\
\hline Geraets 2005 & 89 & $20.4(31.4)$ & 87 & $22.5(26.2)$ & $-\pi$ & $34.75 \%$ & $-0.07[-0.37,0.22]$ \\
\hline Jensen 2001 & 54 & $46.9(21.8)$ & 48 & $41.6(24)$ & - & $33.95 \%$ & $0.23[-0.16,0.62]$ \\
\hline Thieme 2003 & 29 & $3(1.2)$ & 29 & $4.8(0.7)$ & & $31.29 \%$ & $-1.89[-2.51,-1.26]$ \\
\hline 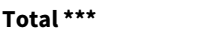 & 172 & & 164 & & & $100 \%$ & $-0.54[-1.51,0.44]$ \\
\hline \multicolumn{8}{|c|}{ Heterogeneity: $\operatorname{Tau}^{2}=0.69 ; \mathrm{Chi}^{2}=33.37, \mathrm{df}=2(\mathrm{P}<0.0001) ; \mathrm{I}^{2}=94.01 \%$} \\
\hline Test for overall effect & & & & & & & \\
\hline
\end{tabular}

Favours experimental

Favours control

Analysis 8.3. Comparison 8 Behavioural vs treatment as usual follow-up, Outcome 3 Mood.

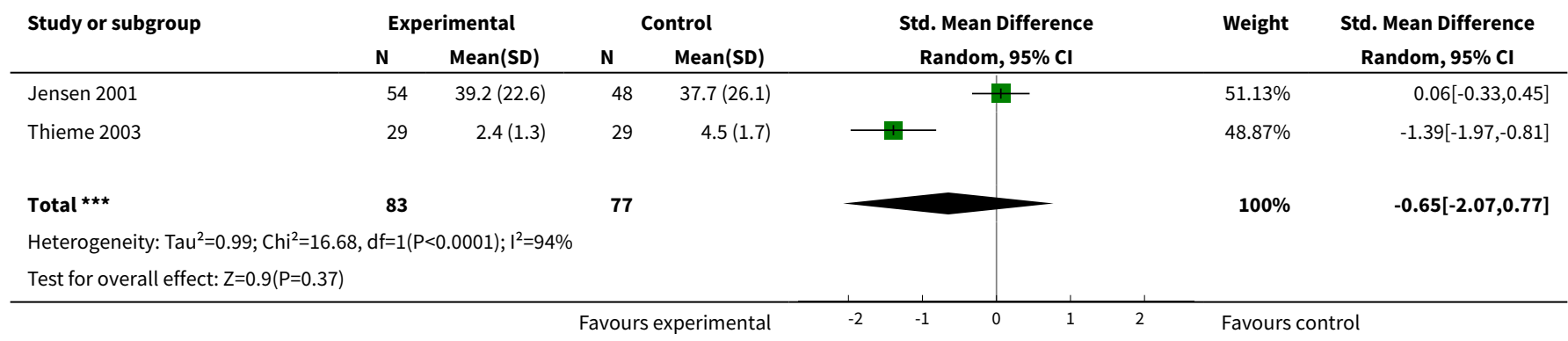

\section{APPENDICES}

\section{Appendix 1. MEDLINE search strategy (via OVID)}

1. PAIN explode all trees (MeSH)

2. (chronic* near pain $\left.{ }^{\star}\right)$

3. (\#1 and (chronic ${ }^{\star}$ near pain $\left.\left.{ }^{\star}\right)\right)$

4. (chronic ${ }^{\star}$ near discomfort)

5. (chronic $^{\star}$ near ache*)

6. (chronic ${ }^{\star}$ near fibromyalgia:ab)

7. (chronic* near fibromyalgia:ti)

8. (chronic ${ }^{\star}$ near neuralgi*:ab)

9. (chronic ${ }^{\star}$ near neuralgi*:ti)

10. (chronic* near dysmenorrhea:ti)

11. (chronic* near dysmenorrhea:ab)

12. (chronic ${ }^{\star}$ near dysmenorrhoea:ti)

13. (chronic* near dysmenorrhoea:ab)

14. (\#1 or \#2 or \#3 or \#4 or \#5 or \#6 or \#7 or \#8 or \#9 or \#10 or \#11 or \#12 or \#13)

Psychological therapies for the management of chronic pain (excluding headache) in adults (Review) 
15. PSYCHOTHERAPY explode tree 1 (MeSH)

16. COGNITIVE THERAPY single term (MeSH)

17. BEHAVIOR THERAPY explode tree 1 (MeSH)

18. BIOFEEDBACK (PSYCHOLOGY) single term (MeSH)

19. ((behaviour ${ }^{\star}$ next therapy) or (behaviour ${ }^{\star}$ next therapies))

20. ((cognitive next therapy) or (cognitive next therapies))

21. $\left(\right.$ relax $^{\star}$ near technique $\left.{ }^{\star}\right)$

22. ((relax ${ }^{\star}$ near therapy) or (relax ${ }^{\star}$ near therapies))

23. meditat*

24. psychotherap*

25. (psychological next treatment)

26. ((psychological next therapy) or (psychological next therapies))

27. (group next therapy)

28. (self-regulation next training)

29. (coping next skill*)

30. (pain-related next thought ${ }^{\star}$ )

31. (behaviour ${ }^{\star}$ near rehabilitat ${ }^{\star}$ )

32. (psychoeducation* next group)

33. (psychoeducation* next groups)

34. (psycho-education* next groups)

35. (psycho-education* next group)

36. (mind and (body next relaxation next technique $\left.{ }^{\star}\right)$ )

37. MIND-BODY AND RELAXATION TECHNIQUES explode tree 1 (MeSH)

38. (\#15 or \#16 or \#17 or \#18 or \#19 or \#20 or \#21 or \#22 or \#23 or \#24 or \#25 or \#26 or \#27 or \#28 or \#29 or \#30 or \#31 or \#32 or \#33 or \#34 or \#35 or \#36 or \#37)

39. (\#14 and \#38)

WHAT'S NEW

\begin{tabular}{lll}
\hline Date & Event & Description \\
\hline 30 September 2019 & Amended & Clarification added to Declarations of interest. \\
\hline 9 February 2016 & Review declared as stable & See Published notes. \\
\hline
\end{tabular}

\section{H I S T O R Y}

Protocol first published: Issue 4, 2008

Review first published: Issue 2, 2009 


Date Event Description

\begin{tabular}{lll}
\hline 27 July 2017 & Amended & Author deceased. See Published notes. \\
\hline 23 March 2016 & Amended & $\begin{array}{l}\text { Amended declarations of interest section (see Declarations of in- } \\
\text { terest). }\end{array}$ \\
\hline 19 December 2012 & Amended & Minor correction to the PLS. \\
\hline
\end{tabular}

13 July $2012 \quad$ New search has been performed

\begin{abstract}
We included 12 new trials from two new searches (Bliokas 2007; Ehrenborg 2010; Glombiewski 2010b; Leeuw 2008; Lindell 2008; Litt 2009; Morone 2008; Schmidt 2011; Thorsell 2011; Van Koulil 2010; Wetherell 2011; Zautra 2008). Thirty four trials included in the previous version were excluded (Astin 2003; Babu 2007; Becker 2000; Bradley 1987; Buhrman 2004 Carson 2005; Cook 1998; Dworkin 1994; Dworkin 2002b; Ersek 2003; Fairbank 2005; Flor 1993; Freeman 2002; Johansson 1998; Keefe 2004; Linton 2008; Marhold 2001; Moore 1985; Newton-John 1995; O'Leary 1988; Peters 1990; Radojevic 1992; Redondo 2004; Spence 1989; Spence 1995; Strong 1998; Turner 1990; Turner 1993; Turner-Stokes 2003; Vlaeyen 1995; Wicksell 2008; Woods 2008). We raised the criterion for entry from $\mathrm{N} \geq 10$ to $\mathrm{N} \geq 20$ in each arm. We added 'Risk of bias' ratings for all included studies. We also added a new outcome: catastrophic thinking.
\end{abstract}

29 March $2012 \quad$ New citation required and conclusions have changed
The evidence for CBT is stronger, particularly when compared with treatment as usual/waiting list, and for mood and catastrophic thinking. The evidence for behaviour therapy is weak or lacking. The field will not be further advanced by more small RCTs of variants of CBT for heterogeneous patient groups but by different trial and analytic methods.

\section{CONTRIBUTIONS OF AUTHORS}

AW oversaw the review and authoring of the manuscript, and authored sections of the manuscript. AW, SM and CE all authored sections of the manuscript, extracted data from papers and made quality ratings. SM advised on statistical strategy. All authors contributed to conceptualisation of the review, selection of papers and judging the quality of the studies.

\section{DECLARATIONS OF INTEREST}

Following discussions with the Cochrane Funding Arbiter in 2015/16, we have revised and expanded our declarations of interest to fully comply with the updated Cochrane Commercial Sponsorship Policy (see http://community-archive.cochrane.org/organisational-policymanual/appendix-5-commercial-sponsorship-policy).

ACdeCW: UCL London received payment from Astellas Pharma Europe for her to speak about the psychology of pain at a general pain meeting in 2015. She is an author of an included study but was not involved in the data extraction or ratings of bias and quality.

CE attended a meeting of IMMPACT in 2011, an organisation that develops outcome measures and consults on analgesic trial design. IMMPACT receives arm's length funding from numerous pharmacological, charitable, and Governmental bodies (including the FDA). Research funding unrelated to this study was received by the University of Bath Centre for Pain Research from Reckitt Benckiser Healthcare during this review production. Since CE is an author as well as the PaPaS Co-ordinating Editor at the time of writing, we acknowledge the input of Andrew Moore who acted as Sign Off Editor for this review. CE had no input into the editorial decisions or processes for this review.

SJM: none known. 


\section{SOURCES OF SUPPORT}

\section{Internal sources}

- No sources of support supplied

\section{External sources}

- Department of Health, UK. Incentive Scheme Grant

\section{DIFFERENCES BETWEEN PROTOCOL AND REVIEW}

1. No data were available in the trials on adverse events, withdrawal and escape or emergency analgesia.

2. No dichotomous outcomes were reported so no numbers needed to treat (NNTs) were calculated.

3. No adjustment for reliability of measures was made.

4. Planned subgroup analyses on doses and on different conditions were not undertaken due to lack of data.

5. The criterion in the protocol of a minimum of 10 participants in each arm for entry into analyses was raised to a minimum of 20 , given the demonstrated association between small numbers and bias (loannidis 2005; Moore 2010; Nuesch 2009).

6. A new outcome variable, catastrophic thinking, was included for all contrasts. This has emerged as a predictor of behavioural and emotional outcomes in the longer term, and is a widely (if not universally) used target of cognitive treatment.

7. Assessment of risk of bias in included studies: this has been expanded to include a fuller description, using the Cochrane Handbook recommendations.

8. Data extraction for 46 of the 60 trials in our penultimate selection (77\%) was done independently by two authors, and the remainder by one.

\section{NOTES}

This is an active area of development but at February 2016 there were no new potentially relevant studies likely to change the conclusions. Therefore, this review has now been stabilised following discussion with the authors and editors. The review will be re-assessed for updating in 2021.

Author Stephen Morley sadly passed away in 2017. The review has been republished in July to reflect this.

\section{INDEX TERMS}

\section{Medical Subject Headings (MeSH)}

Affect; Behavior Therapy [ ${ }^{\star}$ methods]; Chronic Pain [psychology] [*therapy]; Cognitive Behavioral Therapy [methods]; Randomized Controlled Trials as Topic

\section{MeSH check words}

Adult; Humans 